Prepared in cooperation with the U.S. Environmental Protection Agency's Southeast New England Program

Evaluating the Effects of Replacing Septic Systems With Municipal Sewers on Groundwater Quality in a Densely Developed Coastal Neighborhood, Falmouth, Massachusetts, 2016-19

Scientific Investigations Report 2021-5130 
Cover. Hydrologist collects groundwater samples from monitoring wells on a bluff overlooking Great Pond, East Falmouth, Massachusetts, June 2016. Photograph by Timothy McCobb, U.S. Geological Survey. 


\section{Evaluating the Effects of Replacing Septic Systems With Municipal Sewers on Groundwater Quality in a Densely Developed Coastal Neighborhood, Falmouth, Massachusetts, 2016-19}

By Timothy D. McCobb, Jeffrey R. Barbaro, Denis R. LeBlanc, and Marcel Belaval

Prepared in cooperation with the U.S. Environmental Protection Agency's Southeast New England Program

Scientific Investigations Report 2021-5130 


\section{U.S. Geological Survey, Reston, Virginia: 2021}

For more information on the USGS - the Federal source for science about the Earth, its natural and living resources, natural hazards, and the environment—visit https://www.usgs.gov or call 1-888-ASK-USGS.

For an overview of USGS information products, including maps, imagery, and publications, visit https://store.usgs.gov/.

Any use of trade, firm, or product names is for descriptive purposes only and does not imply endorsement by the U.S. Government.

Although this information product, for the most part, is in the public domain, it also may contain copyrighted materials as noted in the text. Permission to reproduce copyrighted items must be secured from the copyright owner.

Suggested citation:

McCobb, T.D., Barbaro, J.R., LeBlanc, D.R., and Belaval, M., 2021, Evaluating the effects of replacing septic systems with municipal sewers on groundwater quality in a densely developed coastal neighborhood, Falmouth, Massachusetts, 2016-19: U.S. Geological Survey Scientific Investigations Report 2021-5130, 39 p., https://doi.org/ 10.3133/sir20215130.

Associated data:

McCobb, T.D., LeBlanc, D.R., Barbaro, J.R., and Belaval, M., 2019, Baseline groundwater-quality data from a densely developed coastal neighborhood, Falmouth, Massachusetts (2016-2020) (ver. 3.0, April 2021): U.S. Geological Survey data release, https://doi.org/10.5066/PGGEMMN6.

U.S. Geological Survey, 2020, USGS water data for the Nation: U.S. Geological Survey National Water Information System database, https://doi.org/10.5066/F7P55KJN.

ISSN 2328-0328 (online) 


\section{Acknowledgments}

The authors thank the officials of the Town of Falmouth, including Raymond Jack, Amy Lowell, and Virginia Valiela, for their support, advice, and assistance with site selection and access.

We will long remember and appreciate the dedicated work of our deceased colleague, Jeffrey Grey, in drilling the wells and collecting cores for this study. The authors recognize the many scientists and students who assisted with drilling and sampling in the field, including Robert "Quinn" Hull, Isaac Bukoski, Ariel Reed, Chelsea Bush, Amory Conant, Jeffrey Wade, and Graham Thomas. Technical advice from Deborah Repert, Richard Smith, JohnKarl Böhlke, and Joseph Levitt is much appreciated. 



\section{Contents}

Acknowledgments ……...................................................................................................................

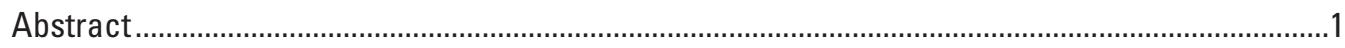

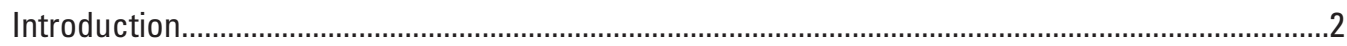

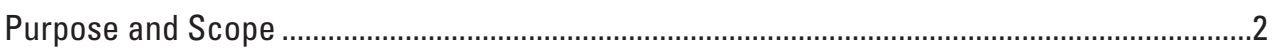

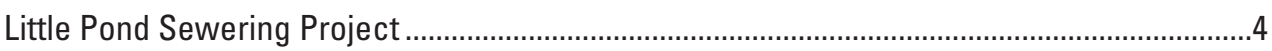

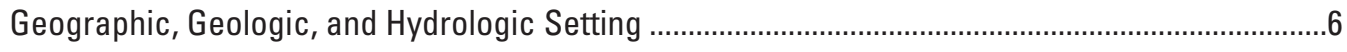

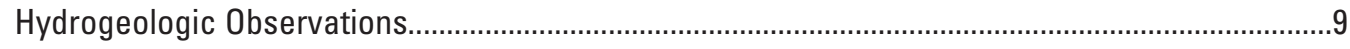

Sediment Characterization and Grain Size ..........................................................................

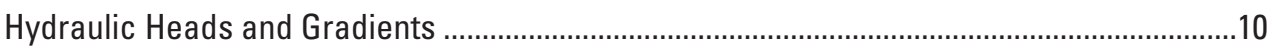

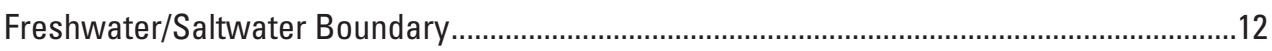

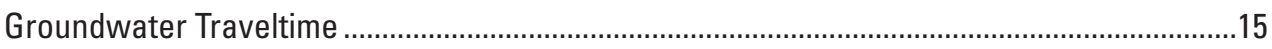

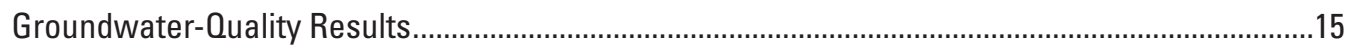

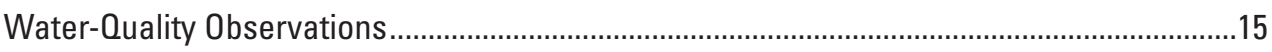

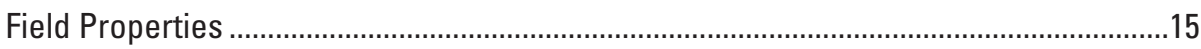

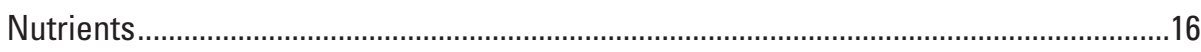

Other Inorganic lons ..................................................................................................

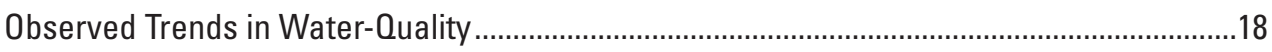

Estimated Nitrate Mass Flux Toward Little Pond.................................................................20

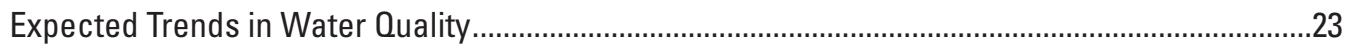

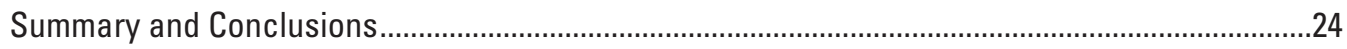

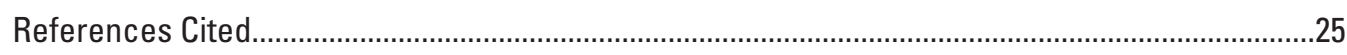

Appendix 1. Methods of Data Collection, Laboratory Analysis, and Trend Evaluation.................28

\section{Figures}

1. Map showing the coastal embayments in southern Falmouth, Cape Cod, Massachusetts, regional water-table contours, and the locations of the Little

Pond Sewer Service Area and the study area on the Maravista peninsula, Falmouth, Massachusetts

2. Map showing network of multilevel samplers and monitoring wells installed in spring 2016 to monitor groundwater quality and water levels beneath a part of Maravista peninsula, East Falmouth, Massachusetts.

3. Map showing extent of Little Pond groundwater watershed as determined by a groundwater-flow model, Falmouth, Massachusetts.

4. Cross section $A-A^{\prime}$ showing the locations of sediment cores, monitoring well and multilevel sampler screens, the vertical position of the freshwater/ saltwater boundary, and sediment classification from cores collected on Maravista peninsula, East Falmouth, Massachusetts.

5. Graphs showing water-table fluctuations at wells MA-FSW 760-0018 and MA-FSW 764-0008 from intermittent measurements made between May 2016 and February 2019 and continuous water levels measured from June 28 to August 2, 2016; and tidal stages at Little Pond, Great Pond, and Woods Hole, Massachusetts, from February to August 2016.

6. Maps showing water-table altitude and hydraulic gradients, Maravista peninsula, East Falmouth, Massachusetts 
7. Map showing freshwater thickness beneath the study area on Maravista peninsula, East Falmouth, Massachusetts.

8. Graphs showing maximum and thickness-weighted mean nitrate concentrations and total nitrate mass per square meter of land area at 15 vertical-profile locations for full sampling rounds in June 2016, April 2017, April 2018, and June 2019, Maravista peninsula, East Falmouth, Massachusetts

9. Graph showing comparison of concentrations of nitrate and boron for 150 samples collected from wells screened in freshwater, June 2016, Maravista peninsula, East Falmouth, Massachusetts.

10. Graphs showing vertical water-quality profiles of inorganic ions at site MAFSW 760-M01, Maravista peninsula, East Falmouth, Massachusetts

11. Graph showing maximum and mean nitrate concentrations for vertical water-quality profiles at two multilevel sampler sites between June 2016 and September 2019, Maravista peninsula, East Falmouth, Massachusetts.

12. Graphs showing distributions of nitrate, groundwater flux, and nitrate mass flux through section $B-B^{\prime}$, Maravista peninsula, East Falmouth, Massachusetts.

\section{Tables}

1. Sample collection dates, analytes, and estimated progress of sewer connections, Maravista peninsula, Falmouth, Massachusetts, June 2016 to June 2019

2. Results from grain-size analysis and estimates of hydraulic conductivity for four sediment samples covering a range of visual sediment characteristics

3. Summary statistics by depth group from the modified Regional Kendall analysis for water samples collected in June 2016, April 2017, April 2018, and June 2019.

4. Summary of calculated nitrate mass flux through section $B-B^{\prime}$ for four sampling rounds using hydraulic gradients from various water-table conditions, Maravista peninsula, East Falmouth, Massachusetts, June 2016 to June 2019 


\section{Conversion Factors}

International System of Units to U.S. customary units

\begin{tabular}{|c|c|c|}
\hline Multiply & By & To obtain \\
\hline \multicolumn{3}{|c|}{ Length } \\
\hline centimeter $(\mathrm{cm})$ & 0.3937 & inch (in.) \\
\hline millimeter $(\mathrm{mm})$ & 0.03937 & inch (in.) \\
\hline meter $(\mathrm{m})$ & 3.281 & foot $(\mathrm{ft})$ \\
\hline kilometer $(\mathrm{km})$ & 0.6214 & mile (mi) \\
\hline \multicolumn{3}{|c|}{ Area } \\
\hline square meter $\left(\mathrm{m}^{2}\right)$ & 0.0002471 & acre \\
\hline hectare (ha) & 2.471 & acre \\
\hline \multicolumn{3}{|c|}{ Volume } \\
\hline cubic centimeter $\left(\mathrm{cm}^{3}\right)$ & 0.06102 & cubic inch $\left(\right.$ in $\left.^{3}\right)$ \\
\hline \multicolumn{3}{|c|}{ Flow rate } \\
\hline cubic meter per day $\left(\mathrm{m}^{3} / \mathrm{d}\right)$ & 35.31 & cubic foot per day $\left(\mathrm{ft}^{3} / \mathrm{d}\right)$ \\
\hline \multicolumn{3}{|c|}{ Mass } \\
\hline $\operatorname{gram}(\mathrm{g})$ & 0.03527 & ounce, avoirdupois (oz) \\
\hline kilogram (kg) & 2.205 & pound avoirdupois (lb) \\
\hline \multicolumn{3}{|c|}{ Density } \\
\hline gram per cubic centimeter $\left(\mathrm{g} / \mathrm{cm}^{3}\right)$ & 62.4220 & pound per cubic foot $\left(\mathrm{lb} / \mathrm{ft}^{3}\right)$ \\
\hline \multicolumn{3}{|c|}{ Hydraulic conductivity } \\
\hline meter per day $(\mathrm{m} / \mathrm{d})$ & 3.281 & foot per day (ft/d) \\
\hline
\end{tabular}

Temperature in degrees Celsius $\left({ }^{\circ} \mathrm{C}\right)$ may be converted to degrees Fahrenheit $\left({ }^{\circ} \mathrm{F}\right)$ as follows:

${ }^{\circ} \mathrm{F}=\left(1.8 \times{ }^{\circ} \mathrm{C}\right)+32$.

\section{Datum}

Vertical coordinate information is referenced to the National Geodetic Vertical Datum of 1929 (NGVD 29).

Horizontal coordinate information is referenced to the North American Datum of 1983 (NAD 83).

Altitude, as used in this report, refers to distance above the vertical datum. 


\section{Supplemental Information}

Specific conductance is given in microsiemens per centimeter at 25 degrees Celsius $(\mu \mathrm{S} / \mathrm{cm}$ at $\left.25^{\circ} \mathrm{C}\right)$.

Concentrations of chemical constituents in water are given in either milligrams per liter (mg/L) or micrograms per liter ( $\mu \mathrm{g} / \mathrm{L})$.

Mass flux of nitrate is given in kilograms per year $(\mathrm{kg} / \mathrm{y})$.

Nitrate mass per square meter of land area is given in milligrams as nitrogen per square meter (mg N/m²).

Trends in nitrate and dissolved-oxygen concentrations over time are reported in milligrams per liter per year (mg/L/y).

Trends in specific conductance over time are reported in microsiemens per centimeter per year $(\mu \mathrm{S} / \mathrm{cm} / \mathrm{y})$.

\section{Abbreviations}

$\begin{array}{ll}> & \text { greater than } \\ < & \text { less than } \\ \text { CCC } & \text { Cape Cod Commission } \\ \text { DO } & \text { dissolved oxygen } \\ \text { EPA } & \text { U.S. Environmental Protection Agency } \\ \text { MLS } & \text { multilevel sampler } \\ \text { SNEP } & \text { Southeast New England Program } \\ \text { SpC } & \text { specific conductance } \\ \text { TIN } & \text { total inorganic nitrogen } \\ \text { TN } & \text { total nitrogen } \\ \text { USGS } & \text { U.S. Geological Survey }\end{array}$




\title{
Evaluating the Effects of Replacing Septic Systems With Municipal Sewers on Groundwater Quality in a Densely Developed Coastal Neighborhood, Falmouth, Massachusetts, 2016-19
}

\author{
By Timothy D. McCobb, ${ }^{1}$ Jeffrey R. Barbaro, ${ }^{1}$ Denis R. LeBlanc, ${ }^{1}$ and Marcel Belaval2
}

\section{Abstract}

Land disposal of sewage wastewater through septic systems and cesspools is a major cause of elevated concentrations of nitrogen in the shallow coastal aquifers of southern New England. The discharge of nitrogen from these sources at the coast is affecting the environmental health of coastal saltwater bodies. In response, local, State, and Federal agencies are considering expensive actions to mitigate these effects, including installing municipal sewer systems. To increase the understanding of the effects of municipal sewering on groundwater quality discharging to coastal surface waters, a network of multilevel monitoring wells was established in a densely developed coastal neighborhood on the Maravista peninsula, Falmouth, Massachusetts, which was undergoing conversion from onsite septic disposal to municipal sewering.

The geohydrology of the study area on the peninsula is generally characterized as consisting of fine to coarse, wellsorted sands containing 2.9 to 9.3 meters of fresh groundwater and a flow system characterized by a groundwater divide slightly west of the center of the peninsula. The magnitude of hydraulic gradients at the water table is gently sloping, ranging from 0.000032 to 0.00059 , and affected by daily and bimonthly tidal fluctuations from adjacent coastal ponds. On the western side of the divide, upgradient from Little Pond, average linear groundwater velocities and traveltimes along shallow flow paths, estimated from observed hydraulic gradients and estimated aquifer hydraulic conductivity and effective porosity, range from 0.076 to 0.094 meters per day and 7.8 to 9.7 years, respectively.

The groundwater monitoring network consists of 14 profile sites on the peninsula that each include a multilevel sampler for water-quality data collection and a shallow monitoring well for groundwater-level measurements. The study area encompasses about 230 residences that transitioned from onsite septic disposal to municipal sewering between spring

\footnotetext{
${ }^{1}$ U.S. Geological Survey.

${ }^{2}$ U.S. Environmental Protection Agency.
}

2017 and summer 2019. An additional multilevel sampler that was in a residential coastal setting but not undergoing sewering also was sampled periodically as a reference site.

Elevated nitrogen, as compared to typical uncontaminated, fresh groundwater in the Cape Cod aquifer, predominately as nitrate, was measured in 15 water-quality profiles at nitrate concentrations as great as 26.2 milligrams per liter as nitrogen $(n=749$; mean and median values were 5.1 and 4.1 milligrams per liter as nitrogen, respectively). At all 14 profile sites and the reference profile site on a nearby peninsula, wastewater effects were denoted by increased nitrate, boron, and specific conductance, and by decreased $\mathrm{pH}$ and dissolved oxygen. The highest concentrations of nitrate typically occurred in the deepest one-half of the freshwater zone and in intervals of suboxic and oxic groundwater.

Thickness-weighted mean and maximum nitrate concentrations, and total nitrate mass from four sampling rounds, provided a metric to evaluate expected changes at the 14 profile sites on the peninsula. Nitrate concentrations varied moderately by site between sampling rounds through both the presewering (June 2016 and April 2017) and transitional periods (April 2018 and June 2019). Nitrate concentrations greater than the U.S. Environmental Protection Agency maximum contaminant level for nitrate in drinking water (10 milligrams per liter as nitrogen), were detected at 9 of the 14 profile sites and at the reference site. The average of the mean thicknessweighted nitrate concentrations for the four full sampling rounds was greater than 5.0 milligrams per liter as nitrogen at 8 sites ( 7 profile sites and the reference site) and greater than 8 milligrams per liter as nitrogen at 3 profile sites. The total nitrate mass per square meter of land area at each profile site ranged from 1,830 to 36,800 milligrams per square meter. Nitrate mass flux, across a 500-meter-long section upgradient from Little Pond and covering about 15 percent of the total pond shoreline length, ranged from 124.3 to 192.6 kilograms per year for the four full sampling rounds under three groundwater-flow conditions.

The expected improvements in groundwater quality in the freshwater zone should be characterized by decreases in concentrations of dissolved total and inorganic nitrogen 
and common ions such as boron, chloride, and fluoride. A statistical analysis using the Regional Kendall test for sampling points grouped in specific depth ranges confirmed that water-quality changes were statistically significant in at least one depth group during the 3-year sampling period (nitrate: -0.76 milligram per liter per year; specific conductance: -12.1 microsiemens per centimeter at 25 degrees Celsius per year; dissolved oxygen: 0.82 milligram per liter per year); however, the rate at which the water-quality improvements will result in decreases in nitrate mass loads to the coastal ponds primarily depends on groundwater traveltimes and the rate of flushing of wastewater constituents from the aquifer.

\section{Introduction}

Rapid population growth and development on Cape Cod over the past several decades (since the 1960s) have caused widespread degradation of water quality from excess nitrogen. Managing excess nitrogen is one of the most pressing environmental challenges facing coastal communities (Valiela and others, 1992, 2000; Nixon, 1995; Short and Burdick, 1996; Howarth and others, 2002). Nitrogen is a limiting nutrient in freshwater and marine systems, where excess nitrogen can reduce water clarity, increase frequency of algal blooms, and decrease dissolved-oxygen (DO) concentrations. These changes adversely affect marine habitat by reducing the extent of beneficial native plant species such as Zostera marina (L.) (eelgrass), by killing fish, and by diminishing shellfish populations. Because of these adverse effects, nitrogen-reduction initiatives are in progress to restore water quality and maintain the healthy aquatic ecosystems relied upon by local communities for tourism, recreation, and commercial fisheries. Wastewater disposal is the largest source of nitrogen in developed areas of Cape Cod (Cape Cod Commission [CCC], 2015). Most towns rely on septic systems for wastewater disposal, resulting in widespread contamination of groundwater with nitrate, the most mobile form of nitrogen in groundwater systems.

Most of the rivers, ponds, and coastal embayments on Cape Cod are subject to Federal and State regulatory requirements to reduce nitrogen loads (CCC, 2015). To achieve required load reductions, nutrient-management planning is currently [2021] in progress following the Section 208 areawide water-quality management plan update, which is a regional, watershed-based strategy (CCC, 2015). The Section 208 plan update provides a flexible framework for developing strategies to reduce nitrogen loads and improve habitat in impaired surface-water bodies on Cape Cod. Traditional (sanitary sewering) and alternative approaches (for example, septic systems and toilets with advanced treatment technologies, constructed wetlands, aquaculture, widening of inlets to coastal embayments, and permeable reactive barriers) for achieving required nitrogen-load reductions to surface-water bodies are being evaluated and implemented. Evaluating the effectiveness of these approaches, in particular determining the magnitude and timing of nitrogen-load reductions to receiving surfacewater bodies, is an important aspect of nutrient-management programs on Cape Cod.

To address required nitrogen-load reductions, existing sewer systems are being expanded in some areas. One such project is the Little Pond Sewering Project in the town of Falmouth, Massachusetts, where about 1,400 properties on the Maravista peninsula and eastern part of the densely developed Falmouth Heights neighborhood were connected to the existing town municipal sewer system during 2017-19 (fig. 1) (Town of Falmouth, 2019b). The goal of the sewering project is to improve water quality in Little Pond by reducing nitrogen loading, primarily as nitrate, from groundwater beneath the peninsula. Properties in the area, which are on small 500- to 1,000-square-meter lots, previously used private on-site treatment and disposal of wastewater through cesspools and conventional septic systems.

In 2015, the U.S. Geological Survey (USGS), in cooperation with the U.S. Environmental Protection Agency's Southeast New England Program (SNEP), started a study to monitor changes in groundwater quality and hydrology on the Maravista peninsula in response to sewer installation. A groundwater monitoring network was installed in an area about 500 meters $(\mathrm{m})$ by $500 \mathrm{~m}$ about halfway down the length of the peninsula (fig. 1). Since June 2016, the network has been sampled periodically to determine water-quality conditions before sewer installation began and during the transitional period when homes were being connected to the new sewer system. The overall goal of the study is to determine the rate and extent of the improvements in groundwater quality (predominantly reductions in nitrate concentrations and loads and changes in reduction-oxidation conditions) and changes in hydrology (predominantly groundwater flow directions and rates) in response to sewer installation. Study results should improve understanding of the timing of nitrate-load reductions to receiving surface waters and other groundwater-quality improvements associated with sewer installation and could help inform wastewater-management planning in other areas on Cape Cod.

This report describes monitoring results during the preconnection (baseline) monitoring period from June 2016 to June 2017, when sewer connections began, and during the transitional monitoring period from June 2017 to September 2019, by which point all the properties in the study area had been connected.

\section{Purpose and Scope}

The purpose of this report is to document the groundwater monitoring network design, groundwater sampling methods, hydrologic and lithologic conditions, and waterquality results from samples collected from the monitoring network on the Maravista peninsula during 11 sampling events -5 events before the start of installation of the 


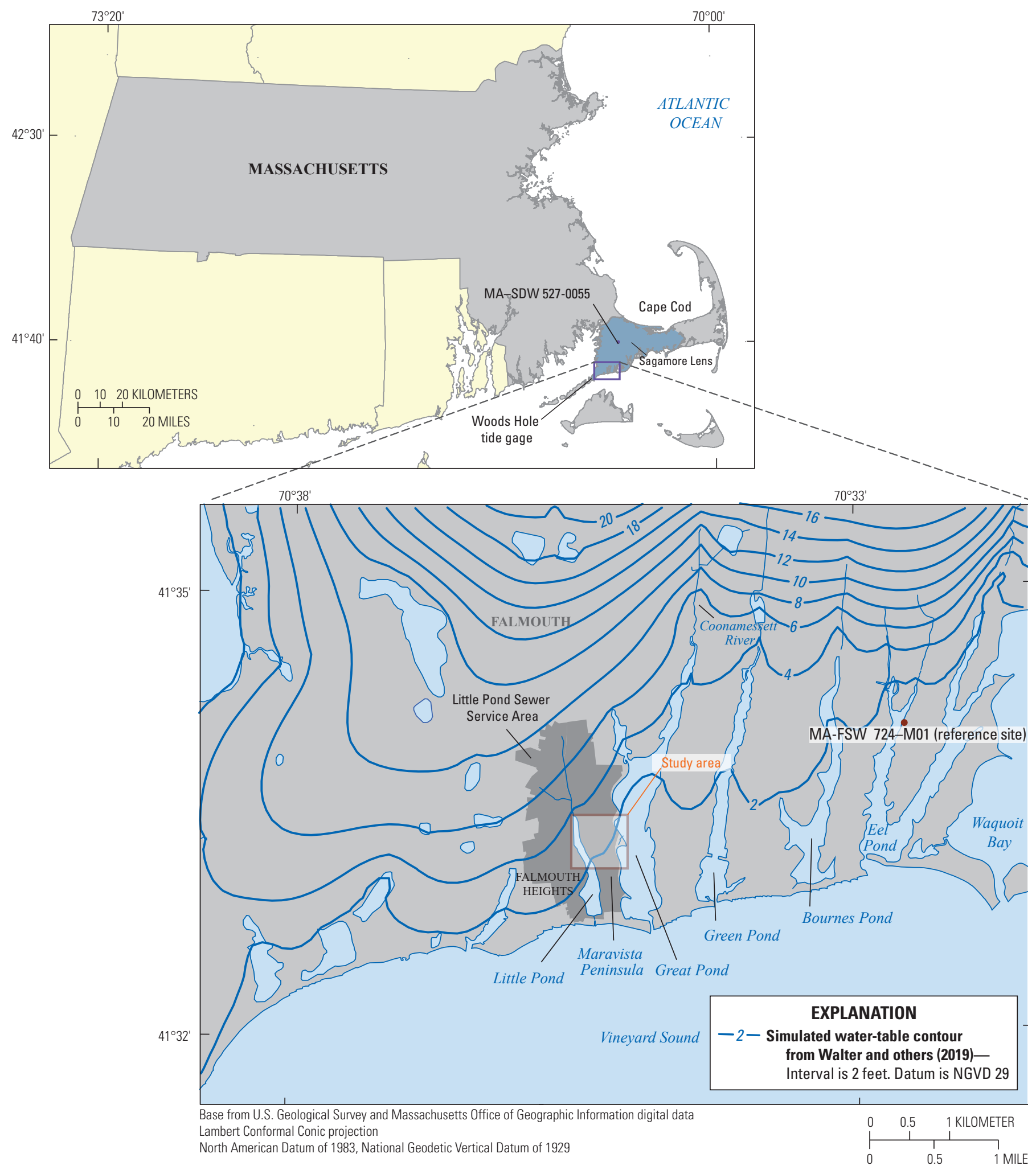

Figure 1. The coastal embayments in southern Falmouth, Cape Cod, Massachusetts, regional water-table contours, and the locations of the Little Pond Sewer Service Area and the study area on the Maravista peninsula, Falmouth, Massachusetts. 
municipal sewers and 6 events during the transitional period when connections were underway. The report provides a baseline for observing and understanding geochemical changes resulting from conversion from onsite septic disposal to municipal sewering. The report also demonstrates an approach that can be used to assess the effectiveness of nitrogenreduction alternatives in similar hydrologic settings.

\section{Little Pond Sewering Project}

The town of Falmouth, Mass., recently (2017-19) connected about 1,400 residential and commercial properties on the Maravista peninsula and eastern part of the Falmouth Heights neighborhood to the existing town municipal sewer system (Little Pond Sewer Service Area, fig. 1). The goal of the Little Pond Sewering Project is to improve water quality in Little Pond by reducing the nitrogen load to the pond that is primarily from nitrate in groundwater beneath the peninsula. Properties in the project area historically used private on-site wastewater treatment methods, including cesspools and septic systems, for wastewater disposal. On-site septic systems generally convert ammonium/ammonia to nitrate by oxidation in the unsaturated zone beneath the system. In coastal zones, nitrate that reaches the groundwater system is generally transported conservatively through the oxic groundwater to a point of discharge in a marine water body (Weiskel and Howes, 1992; DeSimone and Howes, 1996). An assessment from the Massachusetts Estuaries Project concluded that the Little Pond embayment system is impaired because of excessive loading of nutrients from groundwater and surface water, resulting in degraded water quality, adverse effects on ecosystems, and limitations on the use of water resources (Massachusetts Department of Environmental Protection, 2008). A total maximum daily load value for nitrogen to Little Pond was established based on this assessment (Massachusetts Department of Environmental Protection, 2008). A recent CCC watershed report estimated that nitrogen loading to Little Pond will be reduced by 82 percent after all planned connections to the sewer system have been made (CCC, 2017). The new system on the Maravista peninsula was ready for connections in April 2017, and the expected transitional period was about 2 years for residents to connect to the system (Town of Falmouth, 2019b).

This study focuses on the eastern part of the densely developed neighborhood along the Maravista peninsula that is bounded by Little Pond to the west and Great Pond to the east and extends from north to south along Maravista Avenue between Cedar Street and Hiawatha Street (fig. 2). The study area encompasses about 230 properties, although some groundwater flows into the study area from upgradient areas (generally from the north). As of April 2018, about 44 percent of the properties in the study area were connected to the new sewer system; as of July 2019, about 95 percent of all properties in the study area were connected (Town of Falmouth Wastewater Division, written commun., 2019) (table 1).

Table 1. Sample collection dates, analytes, and estimated progress of sewer connections, Maravista peninsula, Falmouth, Massachusetts, June 2016 to June 2019.

[QA/QC, quality assurance/quality control]

\begin{tabular}{|c|c|c|c|c|c|c|}
\hline Date & $\begin{array}{l}\text { Sampling } \\
\text { round }\end{array}$ & $\begin{array}{l}\text { Count, } \\
\text { sites } \\
\text { sampled }\end{array}$ & $\begin{array}{l}\text { Count, } \\
\text { screens } \\
\text { sampled }\end{array}$ & $\begin{array}{l}\text { Count, } \\
\text { QA/QC } \\
\text { samples }\end{array}$ & Analytes ${ }^{1,2}$ & $\begin{array}{l}\text { Approximate percentage of } \\
\text { connections made in study } \\
\text { area (230 properties) }\end{array}$ \\
\hline June 2016 & 1 & 15 & 209 & 28 & Nitrogen species; boron; chloride & 0 \\
\hline September 2016 & 2 & 8 & 56 & 4 & $\begin{array}{l}\text { Nitrogen species including total nitro- } \\
\text { gen; total phosphorus; major ions }\end{array}$ & 0 \\
\hline December 2016 & 3 & 2 & 18 & 2 & Nitrogen species & 0 \\
\hline April 2017 & 5 & 15 & 162 & 15 & Nitrogen species & 0 \\
\hline June 2017 & 6 & 3 & 42 & 5 & Nitrogen species & 3.3 \\
\hline September 2017 & 7 & 2 & 19 & 3 & Nitrogen species & 19.2 \\
\hline April 2018 & 8 & 15 & 162 & 23 & Nitrogen species & 44.1 \\
\hline
\end{tabular}

${ }^{1}$ Nitrogen species include nitrate plus nitrite, ammonium, and nitrite.

${ }^{2}$ Major ion analytes include chloride, fluoride, calcium, magnesium, and sulfate.

${ }^{3}$ Source of connection data: Town of Falmouth Wastewater Division (Town of Falmouth Wastewater Division, written commun., 2019). 


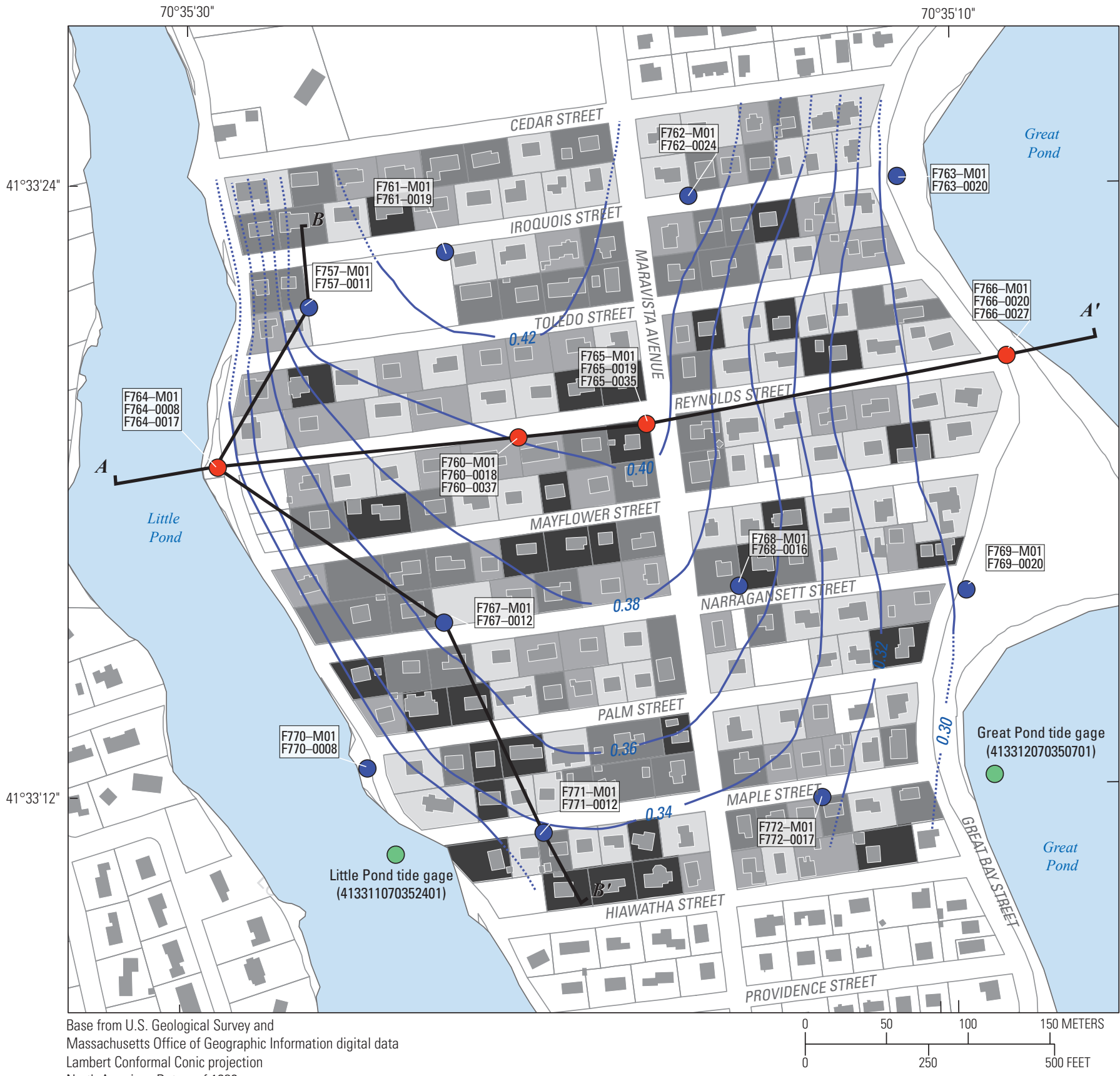

Lambert Conformal Conic projection

North American Datum of 1983

EXPLANATION

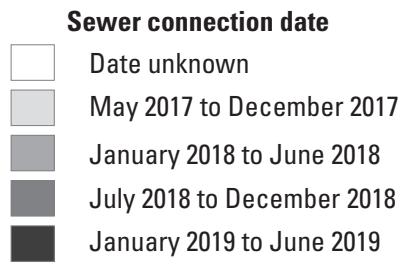

$\begin{array}{cc}\boldsymbol{A}^{\prime} \text { Cross-section line } & \begin{array}{c}\text { Groundwater and surface-water } \\ \text { monitoring site by type }\end{array} \\ \begin{array}{c}\text { Water-level contour on June 27, 2016, } \\ \text { in meters above NGVD 29- }\end{array} & \begin{array}{c}\text { Multilevel sampler and water-table } \\ \text { well and site identifier } \\ \text { Dashed where inferred. } \\ \text { Contour interval is } 0.02 \text { meter }\end{array} \\ & \begin{array}{c}\text { Multilevel sampler, water-table well, } \\ \text { and deep well and site identifier }\end{array} \\ \text { Temporary tide gage and site identifier } \\ \text { "F" in site identifier is shorthand for "MA-FSW" }\end{array}$

Figure 2. Network of multilevel samplers and monitoring wells installed in spring 2016 to monitor groundwater quality and water levels beneath a part of Maravista peninsula, East Falmouth, Massachusetts. 


\section{Geographic, Geologic, and Hydrologic Setting}

The study area is located in the Maravista neighborhood on a peninsula between two saltwater embayments (locally called "ponds") along the south-central coast of Falmouth, Mass. (fig. 1). The coastal neck extends from the main land area of Cape Cod, is about 1,500 m long and 240-550 m wide, and is bounded by Great Pond on the east and Little Pond on the west. The land surface on the peninsula slopes gently from an altitude of about $7.6 \mathrm{~m}$ (relative to the National Geodetic Vertical Datum of 1929 [NGVD 29]) at the north to less than $0.5 \mathrm{~m}$ at the south. In the study area, the land surface rises from about $0.5 \mathrm{~m}$ near the shore of Little Pond to about $6.4 \mathrm{~m}$ on the steep bluff overlooking Great Pond. The tidal ponds occupy valleys that were cut into the glacial outwash plain at the end of the Pleistocene Epoch (Oldale, 1992; Uchupi and others, 1996). The valleys were drowned when sea level rose, leaving areas of the outwash plain as long, narrow peninsulas and coastal necks (Emery, 1969).

Little Pond (fig. 1) is a shallow, narrow 1,370-m-long estuary that is connected to Vineyard Sound by a 4.9-m-wide manmade inlet. Tidal waters flow into and out of the saltwater pond through the inlet, but hydraulic flushing is limited by the narrow channel. Freshwater from the heavily developed watershed enters the pond primarily through direct groundwater discharge and surface-water inflow from a small unnamed stream at the head of Little Pond (Howes and others, 2006). The pond has only one main basin and is shallow, having a mean depth of $0.6 \mathrm{~m}$. The deepest part of Little Pond, about midway along the length of the pond, has a mean depth of only $1.3 \mathrm{~m}$ (Howes and others, 2006). Nearshore bottom sediments are mostly sandy within about $4.5-9.1 \mathrm{~m}$ from shore. The pond bottom in the shallow, northern end and deeper, southern parts of the pond is generally covered by soft organic sediment of variable thickness (as much as $4.5 \mathrm{~m}$ ) (Vanek, 1993).

Great Pond (fig. 1) extends about 3.2 kilometers northward from its inlet at Vineyard Sound to its headwaters at the Coonamessett River. The pond is about $520 \mathrm{~m}$ wide at its widest point. The tidal pond is connected to the sound by a 40-m-wide channel that allows a much greater tidal exchange than at Little Pond. Freshwater enters the pond primarily through direct groundwater discharge and surface-water inflow from the Coonamessett River. The maximum depth of the main basin of Great Pond is about $2.1 \mathrm{~m}$. The nearshore bottom sediments are sandy (Howes and others, 2005).

The Maravista peninsula is at the southernmost part of the Sagamore flow lens, a shallow, unconfined regional aquifer on western Cape Cod (Masterson and others, 1997; Walter and
Whealan, 2005). The aquifer consists of glacial outwash sand and gravel that gets finer with depth into glaciolacustrine sand, silt, and clay (Oldale, 1992; Masterson and others, 1997). The unconsolidated sediments in the study area are about $90 \mathrm{~m}$ thick and rest on relatively impermeable bedrock (Fairchild and others, 2013). The flow lens is the largest and westernmost of six freshwater flow lenses that underlie Cape Cod. Groundwater flows radially outward from the high point of the water table, or groundwater divide, toward natural discharge locations at streams, coastal estuaries, and the ocean. Regional groundwater flowing south from the divide ultimately discharges to Vineyard Sound along the southern coast of Cape Cod. The geology and hydrology of Cape Cod are documented in numerous publications, including LeBlanc and others (1986), Oldale (1992), Uchupi and others (1996), Masterson and others (1997), and Walter and others (2019).

The fresh groundwater system beneath the Maravista peninsula is bounded by the water table at the top, the freshwater/saltwater boundary at the bottom, and laterally by the tidal saltwater bodies (Little and Great Ponds, figs. 3 and 4). The area receives on average about 114 centimeters per year of precipitation, of which slightly more than 50 percent recharges the aquifer at the water table; the remainder is lost to evapotranspiration (LeBlanc and others, 1986). The simulated Little Pond groundwater watershed - the aquifer area contributing groundwater flow to the pond - covers a land area of about 313 hectares extending to the north-northwest of Route 28 in Falmouth (CCC, 2017) (fig. 3).

Millham and Howes (1994) indicated in earlier work to map water-table elevations near Little Pond that the coastal ponds are areas of groundwater discharge and that the upgradient groundwater watershed has a generally southeastward sloping water table. In general, hydraulic gradients and associated groundwater-flow directions are focused toward the surface-water features, and most of groundwater inflow to Little Pond is at the northern end of the pond. This work also determined that the magnitude of hydraulic gradients along the southern parts of these coastal necks is low, similar to gradients observed by Colman and others (2018) beneath a nearby peninsula to the east. Horizontal hydraulic gradients of about 0.0003 were reported along a northwest-to-southeast flow path near the center of the peninsula east of Little Pond. Walter and Whealan (2005) estimated the horizontal hydraulic conductivity of the sand and gravel to be about 60 to 110 meters per day $(\mathrm{m} / \mathrm{d})$. Given this hydraulic conductivity range, the observed hydraulic gradient, and an effective porosity of 0.39 (Garabedian and others, 1991), Darcy's Law calculations indicate that the average linear groundwater velocity in these low-gradient areas ranges from about 0.05 to $0.08 \mathrm{~m} / \mathrm{d}$ (Fetter, 1994). 


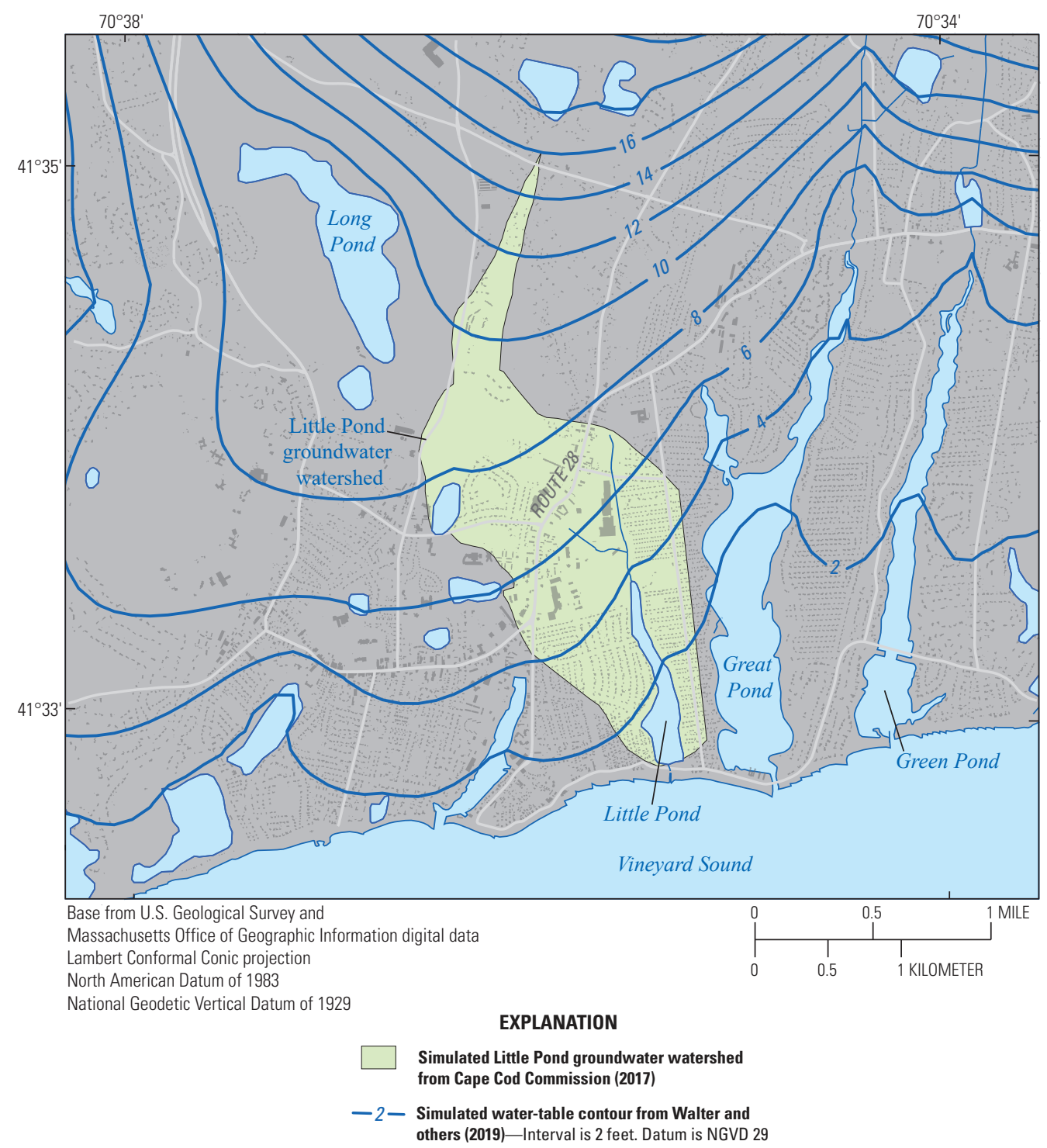

Figure 3. Extent of Little Pond groundwater watershed as determined by a groundwater-flow model, Falmouth, Massachusetts.

Regional hydrologic conditions, as indicated by water levels in a nearby long-term recording well (MA-SDW 527-0055), were generally dry between summer 2016 and spring 2018 (less than $[<]$ 25-50 percentile for the period of record), and, in general, water levels increased steadily to above-mean conditions through late 2018 and 2019 (fig. 1; USGS, 2021).

Drinking water is supplied to the homes on the peninsula by the municipal water system for Falmouth, Mass. The system obtains its water from wells and a groundwater-fed lake in inland areas of the town. Water-use records from 2010 indicate a mixture of year-round and seasonal homes. About 40 and 30 percent of the homes use an average (during
2010) of $<50$ and $>100$ gallons per day, respectively (CCC, 2018). About 1,100 homes are in the Maravista neighborhood (between Route 28 and Vineyard Sound) with a total water use (on average during 2010) of about 107,000 gallons per day. Before 2017, most of this water recharged the local groundwater-flow system through on-site wastewater disposal, equivalent based on 2010 water use to about 20 percent of the natural recharge from precipitation. Water-quality data from the town's 2019 Annual Drinking Water Report indicated low nitrate levels (average detection was 0.44 milligram per liter $[\mathrm{mg} / \mathrm{L}]$ ) in the drinking-water supply (Town of Falmouth, 2019a). 


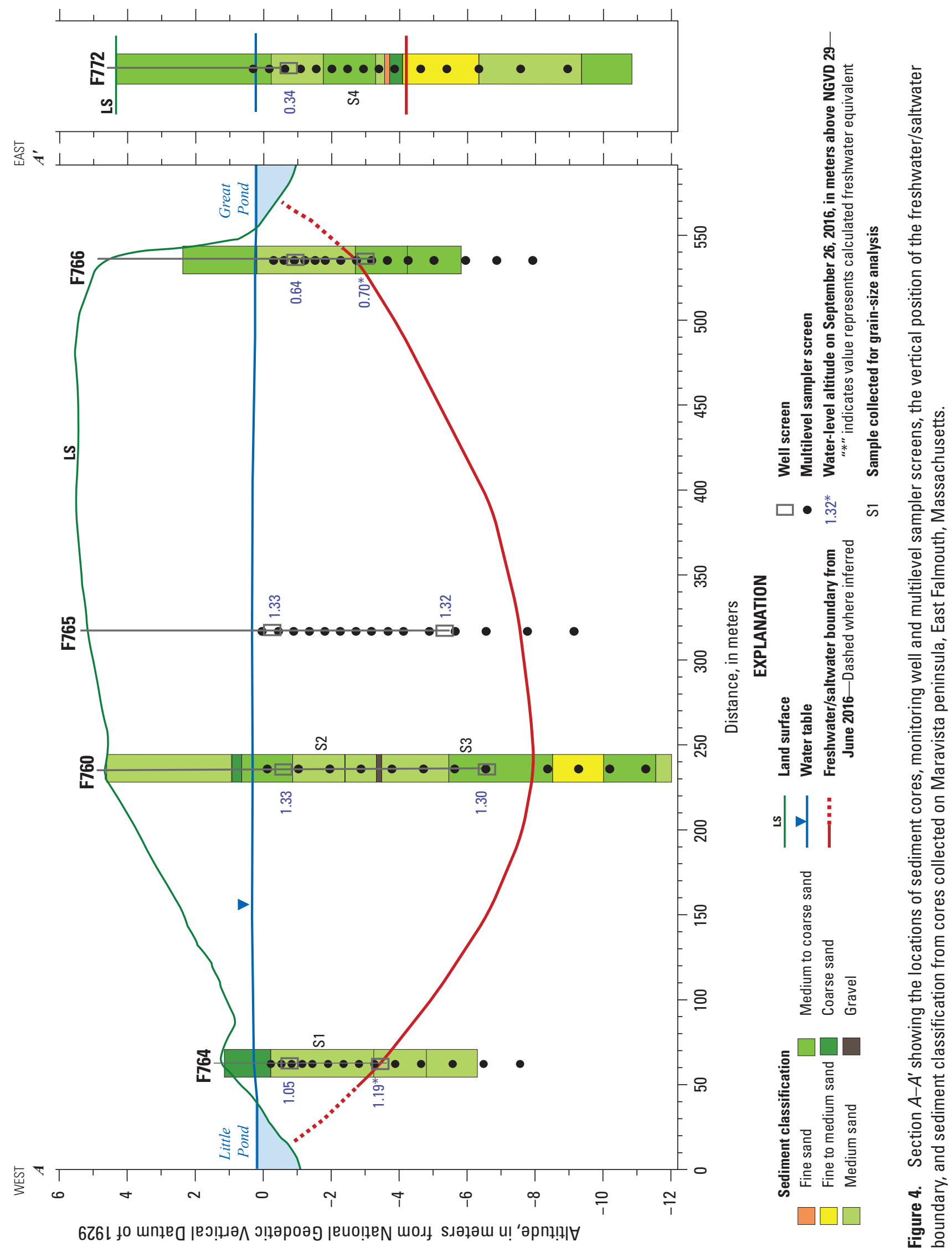




\section{Hydrogeologic Observations}

In spring 2016, a network of multilevel samplers (MLS), monitoring wells, and temporary tide gages was established in the Maravista neighborhood to assess hydrologic and geochemical conditions. The network installation, data collection, and data analysis followed established techniques that are documented in USGS field and laboratory protocols (Cunningham and Schalk, 2011; USGS, variously dated). The descriptions of project-specific aspects of network design and data collection are in appendix 1. Results from the hydrologic monitoring are available in the USGS National Water Information System database (USGS, 2019), available at https://doi.org/10.5066/ F7P55KJN. All monitoring-site construction and location information and water-quality data are tabulated in the USGS data release available at https://doi.org/10.5066/P9GEMMN6 (McCobb and others, 2019).

\section{Sediment Characterization and Grain Size}

Wells and MLS were installed at 14 profile sites shown in figure 2 by using direct-push drilling. Continuous cores of aquifer sediments were collected at four sites (F760, F764, F766, and F772) during drilling to determine subsurface lithologic conditions and the approximate depth of the freshwater/ saltwater boundary. Details of network design, well installation, and sediment collection are in appendix 1 . Three of the coring sites (F764, F760, F766) are on section $A-A$ ' along Reynolds Street near the middle of the study area. The fourth coring site (F772) is on Maple Street about $250 \mathrm{~m}$ south of section $A-A^{\prime}$ (figs. 2 and 4 ).

Cored material was examined visually to create lithostratigraphic logs of sediment characteristics, including sediment type and texture, presence of sediment layering, sorting, and color. Sediment types were grouped by Unified Soil Classification System major divisions (American Society for Testing and Materials, 1985) and then subdivided into six subcategories describing sediment encountered in the study area (fig. 4).

The glacial sediments under the Maravista peninsula consist of outwash deposits consistent with deltaic glaciolacustrine foreset beds on Cape Cod (Oldale, 1992; Masterson and others, 1997). In general, fine to coarse, well-sorted sands were encountered throughout each of the four geologic borings, and none had significant units of fine-grained sediments (silts and clays). The presence of fine-grained sand increased with depth at each location except for site F764, where only medium sand was encountered. At sites F760 and F772, a layer of fine to medium sand was present in a 1.5- to 2-m-thick zone just below the freshwater/saltwater boundary (fig. 4).

The grain-size distributions for four subsamples (F764S1, F760-S2, F760-S3, and F772-S4, fig. 4), all from the freshwater zone and representing a range of visual sediment characteristics, were used to estimate hydraulic conductivity. The grain-size distributions for the subsamples are shown by effective grain diameter in table 2. Mean hydraulic-conductivity estimates obtained by using as many as 13 empirical and semi-empirical methods applicable for the measured grainsize distributions (Devlin, 2015) ranged from 26 to $120 \mathrm{~m} / \mathrm{d}$. Coefficients of uniformity were all $<4$, indicating well-sorted material. The hydraulic-conductivity estimates for two samples at site F760 near the center of the peninsula (fig. 2), both classified as moderately well-sorted sand with little fines, were lower $(26-46 \mathrm{~m} / \mathrm{d})$ than estimates from samples at sites F764 and F772 (79-120 m/d), which were classified as moderately well-sorted sand with little gravel.

Table 2. Results from grain-size analysis and estimates of hydraulic conductivity for four sediment samples covering a range of visual sediment characteristics.

[Source of sediment data: U.S. Geological Survey Kentucky Sediment Laboratory, Louisville, Kentucky. Locations of sites shown in figures 2 and 4]

\begin{tabular}{|c|c|c|c|c|c|c|c|c|c|c|c|c|c|c|}
\hline \multirow[b]{2}{*}{ Site name } & \multirow{2}{*}{$\begin{array}{l}\text { Sam- } \\
\text { ple } \\
\text { iden- } \\
\text { tifier }\end{array}$} & \multirow{2}{*}{$\begin{array}{c}\text { Total } \\
\text { sample } \\
\text { mass, in } \\
\text { grams }\end{array}$} & \multirow{2}{*}{$\begin{array}{c}\text { Bottom } \\
\text { depth, in } \\
\text { meters }\end{array}$} & \multirow{2}{*}{$\begin{array}{l}\text { Bottom } \\
\text { alti- } \\
\text { tude, in } \\
\text { meters }\end{array}$} & \multirow[b]{2}{*}{ Field description } & \multicolumn{7}{|c|}{ Effective grain diameter, in millimeters } & \multirow{2}{*}{$\begin{array}{c}\text { Coef- } \\
\text { ficient of } \\
\text { unifor- } \\
\text { mity }^{1}\end{array}$} & \multirow{2}{*}{$\begin{array}{c}\text { Mean } \\
\text { hydraulic } \\
\text { conductivity, } \\
\text { in meters per } \\
\text { day }\end{array}$} \\
\hline & & & & & & d5 & d10 & d16 & d50 & d60 & d84 & d95 & & \\
\hline $\begin{array}{l}\text { MA-FSW } \\
764\end{array}$ & $\mathrm{~S} 1$ & 421.2 & 7.62 & -3.24 & $\begin{array}{l}\text { Medium sand, tan; } \\
\text { well sorted }\end{array}$ & 0.208 & 0.291 & 0.376 & 0.898 & 1.152 & 2.907 & 19.6 & 3.95 & 79 \\
\hline $\begin{array}{l}\text { MA-FSW } \\
760\end{array}$ & S3 & 338 & 10.67 & -5.43 & $\begin{array}{l}\text { Medium sand, brown; } \\
\text { well sorted }\end{array}$ & 0.17 & 0.228 & 0.272 & 0.452 & 0.513 & 0.862 & 1.27 & 2.25 & 46 \\
\hline $\begin{array}{l}\text { MA-FSW } \\
772\end{array}$ & S4 & 221.3 & 4.57 & -3.22 & $\begin{array}{l}\text { Medium-coarse sand, } \\
\text { tan; little gravel }\end{array}$ & 0.275 & 0.349 & 0.438 & 0.929 & 1.213 & 3.146 & 16.6 & 3.47 & 120 \\
\hline
\end{tabular}

${ }^{1}$ Coefficient of uniformity less than 4 indicates well-sorted material.

${ }^{2}$ Hydraulic conductivity was determined as mean value (arithmetic) from as many as 13 applicable equations included in the HydrogeoSieveXL software (Devlin, 2015); for temperature-dependent equations, a temperature of 10 degrees Celsius was used. 


\section{Hydraulic Heads and Gradients}

Water levels were measured during each sampling round in shallow wells with screens set within $2 \mathrm{~m}$ of the water table at the 14 monitoring sites and in wells with deeper screens at the four sites along section $A-A^{\prime}$ (F764, F760, F765, and F766) (fig. 2). Water-level altitudes in the study area are generally greatest at the inland locations to the north along Iroquois Street (sites F761 and F762) and decrease toward the south and towards the two coastal ponds. A groundwater divide generally runs from just west of Maravista Avenue near Iroquois Street to near Maravista Avenue at Maple Street. Groundwater to the west of the divide flows to Little Pond; groundwater east of the divide flows to Great Pond. The thickness of the unsaturated zone at the observation sites ranged from $0.08 \mathrm{~m}$ (site F770) to $5.9 \mathrm{~m}$ (site F763).

In the area near site F760 (fig. 2) where groundwater flow is toward Little Pond, water-level altitudes from discrete measurements made in two shallow wells on section $A-A^{\prime}$ and screened near the water table ranged from 0.36 to $0.53 \mathrm{~m}$ above NGVD 29 in well F760-0018 near the groundwater divide and from 0.32 to $0.45 \mathrm{~m}$ in well F764-0008 $175 \mathrm{~m}$ west of site F760 and within $25 \mathrm{~m}$ of Little Pond. Although the water-level ranges at the two wells overlapped, the water-level altitude at a given time at inland site F760 was always higher ( $0.07 \mathrm{~m}$ on average) than the altitude at nearshore site F764.

Water-level altitudes from discrete measurements in the deep wells at locations away from the coastal ponds along section $A-A^{\prime}$ (sites F760 and F765) were consistently lower $(0.01$ to $0.03 \mathrm{~m})$ than water-level altitudes in the shallow wells at the sites, indicating downward flow characteristic of a groundwater recharge zone. In contrast, the well pairs at the two sites near the pond shores (sites F764 and F766) showed higher water levels in the deeper wells $(0.07 \mathrm{~m}$ higher on average), indicating upward flow characteristic of a groundwater discharge zone.

Discrete measurements during and between many sampling rounds suggested that water levels may change during sampling events, particularly at the sites nearest the coastal ponds (fig. $5 \mathrm{~A}$ ). To examine the magnitude of these changes temporally and spatially, continuous water-level loggers were installed in each of the 14 shallow monitoring wells, and water levels were recorded on 15-minute intervals for a 35-day period from June 28 to August 2, 2016 (fig. 5B).

Tidal stage measurements also were collected on 15-minute intervals at Little Pond and Great Pond between February 18 and March 25, 2016, at locations opposite the western and eastern ends of Maple Street (fig. 2) and compared to the tidal stage of Vineyard Sound at Woods Hole (National Oceanic and Atmospheric Administration station 8447930, National Oceanic and Atmospheric Administration, 2019, fig. 1). The stages of the coastal ponds reflected variations in daily tides and bimonthly variations in tide-range magnitudes (fig. 5C). The stage of Little Pond during the period of measurement ranged from 0.0550 to $0.669 \mathrm{~m}$ above NGVD 29, with a mean stage of $0.254 \mathrm{~m}$. The stage of Great
Pond ranged from -0.199 to $0.896 \mathrm{~m}$ above NGVD 29, with a mean stage of $0.283 \mathrm{~m}$. The mean ranges of tide (high to low tide in a tidal cycle) for the period for Little Pond and Great Pond were $0.126 \mathrm{~m}$ and $0.468 \mathrm{~m}$, respectively. Tidal response time at Little Pond lagged that at Great Pond by about 1.6 hours on average. The long-term Woods Hole tide station, in Vineyard Sound about 7.5 kilometers west of the outlet of Little Pond, historically has a mean range of tide of $0.546 \mathrm{~m}$ (National Oceanic and Atmospheric Administration, 2019). The apparent time lag and muted magnitude of tidal response of the coastal ponds relative to tides in Vineyard Sound reflect each coastal pond's connection with the open water of the sound. Little Pond is connected to the sound through a narrow, 5-m-wide channel that restricts the tidal exchange, whereas Great Pond has a greater tidal exchange because of its connection to the sound through a 40-m-wide channel.

The continuous records of groundwater levels show that water levels in the study area are affected to varying degrees by daily and bimonthly tides. Water levels in the shallow wells at sites F764 and F760 varied considerably during the 35-day period, ranging, for example, from 0.235 to $0.495 \mathrm{~m}$ above NGVD 29 at site F764 and from 0.299 to $0.517 \mathrm{~m}$ above NGVD 29 at site F760 (fig. 5B). Daily water-level fluctuations caused by the tides were significantly greater at sites closest to the ponds. At the two locations closest to Little Pond (sites F764 and F770), the range in tidal fluctuations in groundwater levels averaged $0.10 \mathrm{~m}$. Tidally induced groundwater-level fluctuations at sites near Great Pond (F763 and F766) averaged $0.189 \mathrm{~m}$. At site F765 near the center of the peninsula, tidal fluctuations in groundwater levels averaged only about $0.06 \mathrm{~m}$.

The magnitude of groundwater-level variation caused by bimonthly variations in daily tidal range were similar at sites F764 and F760. The difference in daily mean water levels between the two sites (as observed from the continuous data) was consistently between 0.03 and $0.11 \mathrm{~m}$, with an average of $0.07 \mathrm{~m}$, similar to the difference observed from the discrete measurements (figs. $5 A$ and $B$ ). A small decrease in the difference and a resulting decreased hydraulic gradient was detected during bimonthly periods when tide ranges were increasing versus periods when tide ranges were decreasing. During bimonthly periods when the tide range was decreasing, a slight increase in hydraulic gradient between the two sites was observed.

To reduce the complexities introduced by short-term temporal differences caused by tidal effects on interpretation of hydraulic gradients and flow directions, water-level altitudes were evaluated at selected times based on maximum (July 11, 2016, 00:00 hours) and minimum (July 19, 2016, 22:00 hours) water levels recorded at well F760-0018 near the center of the peninsula, and as the mean daily mean water levels for each site during the 35-day period from June 27 to August 2, 2016. The maximum and minimum water levels during this period were similar in magnitude to the discrete measurements made 


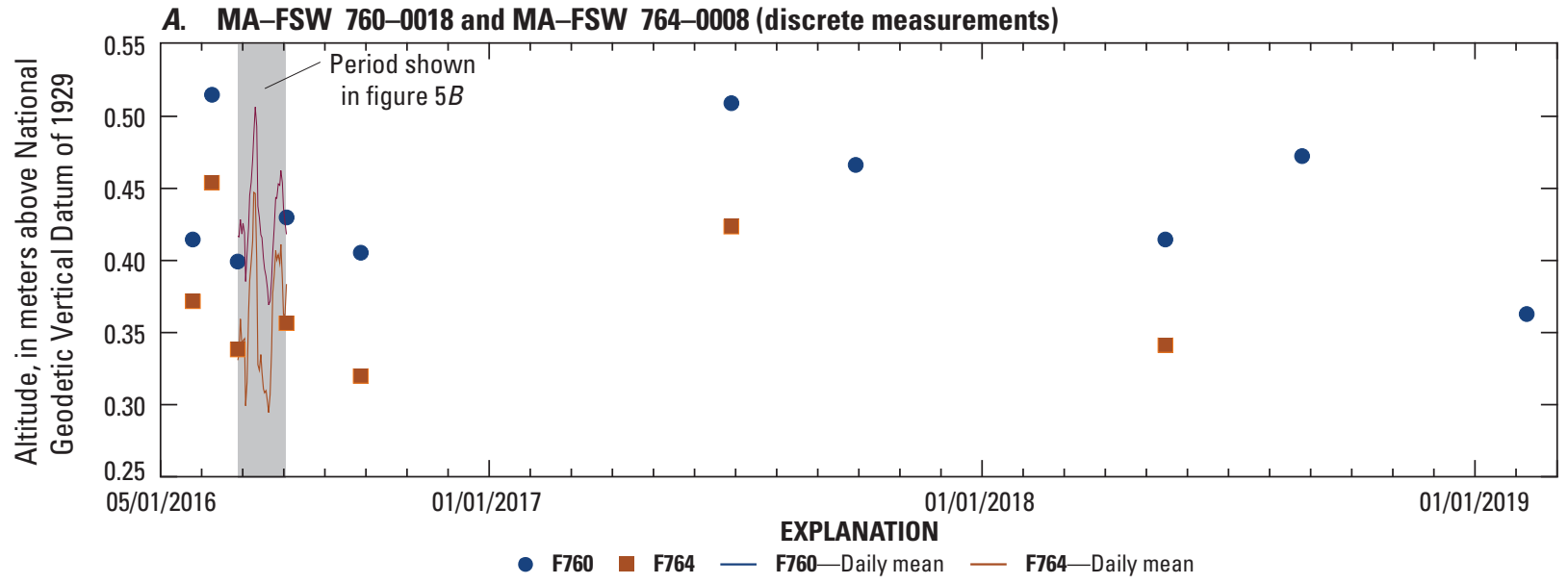

B. MA-FSW 760-0018 and MA-FSW 764-0008 (15-minute [min] continuous recorder)

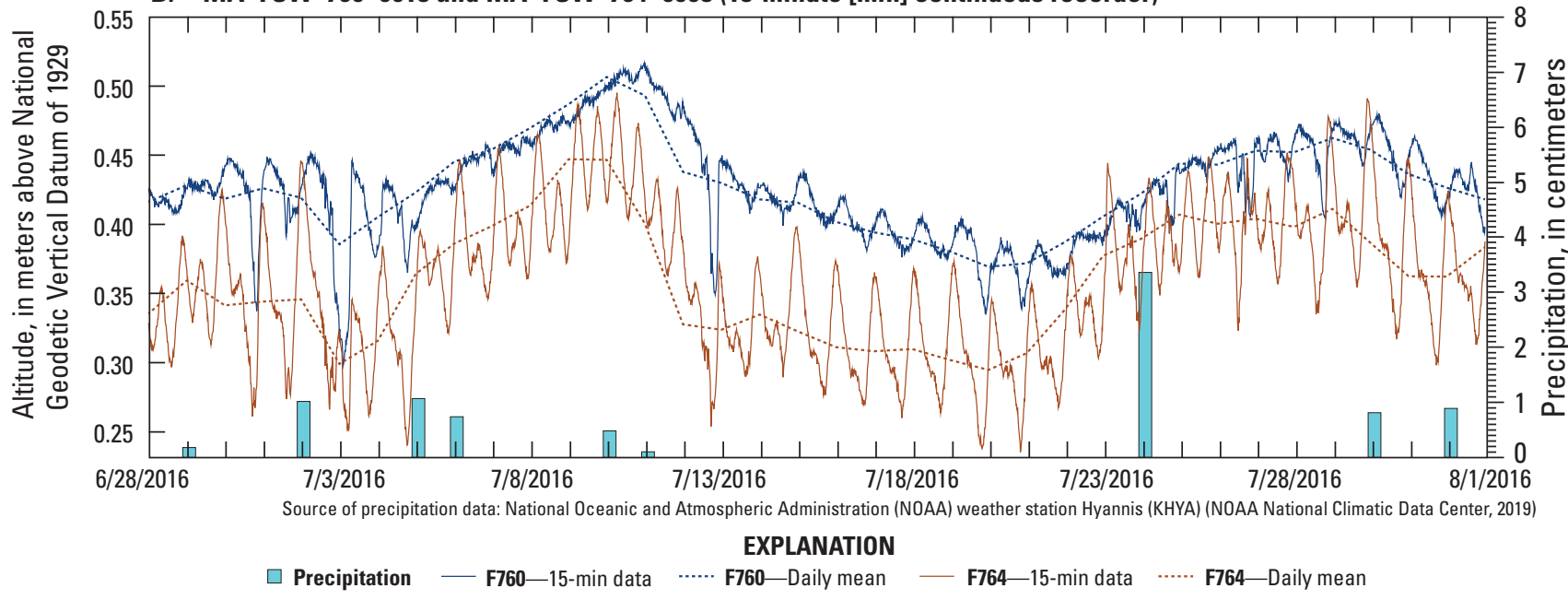

C. Tidal stage at Little Pond (413311070352401), Great Pond (413312070350701), and Woods Hole, MA (NOAA station 8447930)

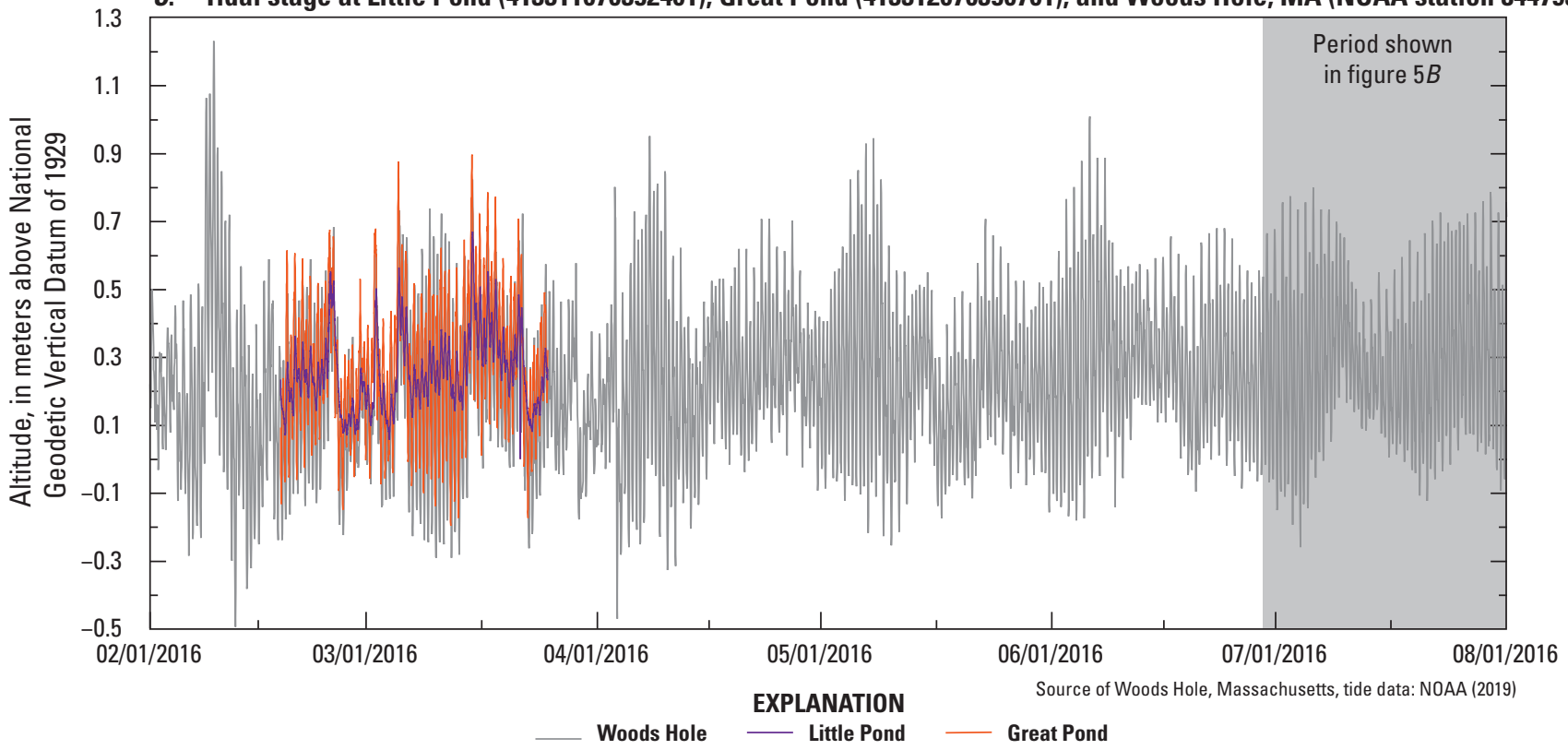

Figure 5. Water-table fluctuations at wells MA-FSW 760-0018 and MA-FSW 764-0008 from $A$, intermittent measurements made between May 2016 and February 2019 and B, continuous water levels measured from June 28 to August 2, 2016; and $C$, tidal stages at Little Pond, Great Pond, and Woods Hole, Massachusetts, from February to August 2016. 
throughout the study (2016-19). The three datasets were used to characterize hydraulic gradients, flow directions, and nitrate mass flux under high, low, and average water-level regimes.

The local groundwater divide, which separates areas of flow toward Little and Great Ponds, is generally aligned slightly to the west of the center of the peninsula during all three regimes, as is also indicated by the discrete measurements. Water-level altitudes decrease from north to south and from the divide toward the coastal ponds. However, a comparison of the three water-table maps shows the dynamic temporal nature of hydraulic gradients, which can vary over a few hours (fig. 6).

The hydraulic gradient based on contoured watertable altitudes when water levels were near their maximum (July 10, 2016 at 11:30 at well F760-0018) sloped gently in the southerly direction approximately along Maravista Avenue (fig. 6A). The mean magnitude of the gradient along the divide was 0.00009 . The lateral hydraulic gradients to the east and west of the divide sloped more steeply toward the two ponds; these lateral gradients were the largest among the three watertable maps shown in figure 6. Gradients nearest Little Pond had a mean magnitude of about 0.00020; gradients near Great Pond had a mean magnitude of about 0.00033 . These gradients are low, however, compared to most other areas in the interior of Cape Cod.

When water levels were near their minimum (July 19, 2016 at 22:00 at well F760-0018), the approximate location of the groundwater divide is shifted westward toward Little Pond, particularly near sites F761 and F762 (fig. 6B). The gently sloping southerly hydraulic gradient observed along Maravista Avenue at highest water levels persists at lowest water levels. On the eastern side of Maravista Avenue, gradients are more southerly rather than eastward toward Great Pond and more gradual compared to gradients during high water levels (mean of 0.00006). However, the magnitude and direction of hydraulic gradients near Little Pond are similar to those during the high and average daily-mean conditions. Hydraulic gradients calculated from the mean of daily-mean values represent an average condition over the 2-month period of continuous data and are generally intermediate between gradients during the maximum and minimum conditions (fig. $6 \mathrm{C}$ ).

Based on configuration of the water-table contours and location of the groundwater divide for each water-level regime, the area contributing groundwater discharge to Little Pond is about 38,35 , and 31 percent of the total study area for the maximum, minimum, and average daily-mean regimes, respectively (figs. $6 A-C$ ).

The 15-minute water-level data show spatial differences in the temporal variations of hydraulic gradients in the groundwater system under the Maravista peninsula. In general, the direction and magnitude of the horizontal hydraulic gradient varies temporally on the time scale of hours. The magnitude and direction of gradients near Little Pond change little over time as compared to gradients upgradient from Great Pond, where temporal changes are larger owing to the larger tidal influence. Water levels near the shore respond more quickly to tides than water levels in inland areas. During low surfacewater levels (low tide stages), inland hydraulic gradients are periodically and temporarily increased until the tidal influence propagates to the center of the peninsula. During high-tide periods at the coastal ponds, gradients are flattened as the tidal response propagates inland toward the center of the peninsula.

\section{Freshwater/Saltwater Boundary}

The thickness of the fresh groundwater lens was determined by sampling all MLS ports during the initial full sampling round in June 2016. The initial sampling showed that 47 of 209 MLS ports are below the freshwater/saltwater boundary, as defined by a specific conductance $(\mathrm{SpC})$ value greater than 3,000 microsiemens per centimeter at 25 degrees Celsius $(\mu \mathrm{S} / \mathrm{cm})$. Typical uncontaminated, fresh groundwater in the Cape Cod aquifer has a SpC of $<100 \mu \mathrm{S} / \mathrm{cm}$ (LeBlanc, 1984). The freshwater thickness ranges from $9.3 \mathrm{~m}$ at site F761 at the northern boundary of the study area to $2.9 \mathrm{~m}$ at site F770 on the shore of Little Pond. The thickness of the freshwater lens is, in part, dependent on the height of the water table above sea level. The height of the water table is related to area of the land mass, recharge rates, and hydraulic properties of the aquifer. In the study area, the thickest part of the freshwater lens was in the areas of highest groundwater levels near the center of the peninsula and along the north boundary of the study area (fig. 7). The average freshwater thickness in the study area is $5.8 \mathrm{~m}$.

Given the differences in density between saltwater and freshwater and limited dispersion in the aquifer (Garabedian and others, 1991), mixing between freshwater and saltwater at the boundary was limited, although a thin transitional mixing zone of brackish water was detected at many locations. In general, these transition zones occurred over a $<2$-m-thick vertical interval (see appendix fig. 1.1 at the back of the report for $\mathrm{SpC}$ profiles). The position and potential movement of the boundary as water levels varied over time was not monitored because of the large vertical spacing ( 0.9 to $1.4 \mathrm{~m}$ ) of the deepest sampling ports and the focus of sampling on the freshwater zone after the initial sampling round in June 2016.

The Ghyben-Herzberg relation relates the height of the free groundwater surface (the water table) to the depth of the freshwater/saltwater boundary based simply on the relative densities of fresh and saltwater (Barlow, 2003). The key assumption of this approach is that equipotential lines in the freshwater zone are vertical (that is, groundwater flow is horizontal, and the flow system is hydrostatic). Given the densities of freshwater (1.000 gram per cubic centimeter) and seawater (1.025 grams per cubic centimeter), the Ghyben-Herzberg relation predicts that the thickness of freshwater below local sea level is about 40 times the height of the water table above local sea level. In the study area, the average of the mean stages of Little and Great Ponds from data collected in early 2016 is about $0.27 \mathrm{~m}$ above NGVD 29, and the mean watertable altitude at site F761 is about $0.46 \mathrm{~m}$ above NGVD 29 
A. Maximum water-level condition at well MA-FSW 760-0018 (7/11/2016 00:00)

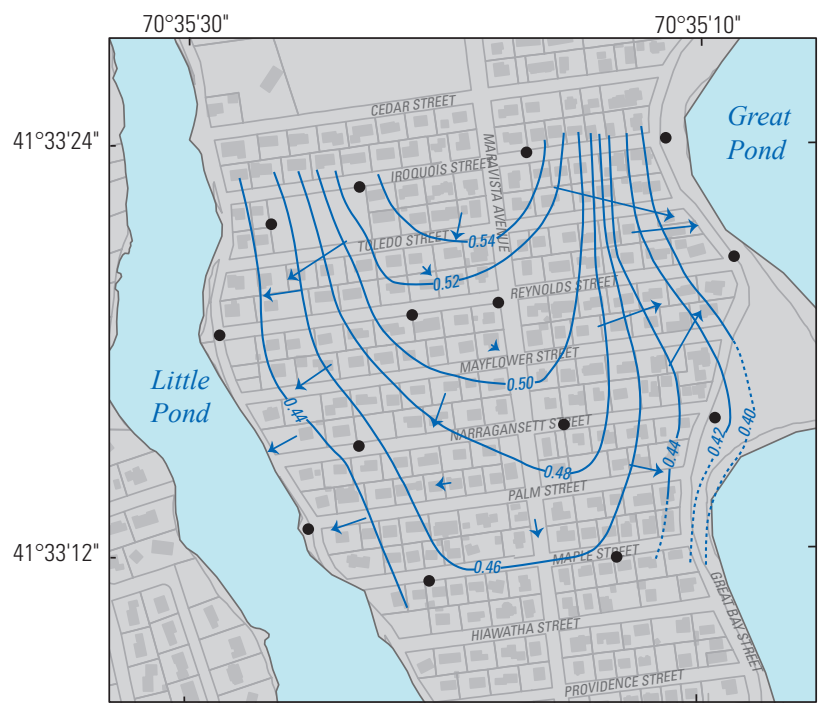

C. Mean daily mean water level

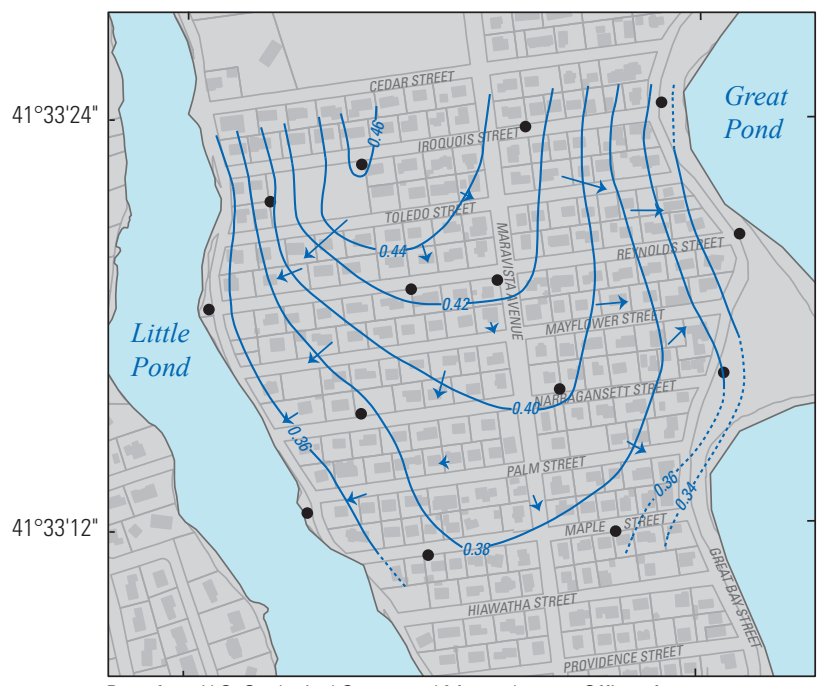

Base from U.S. Geological Survey and Massachusetts Office of

Geographic Information digital data

Lambert Conformal Conic projection

North American Datum of 1983, National Geodetic Vertical Datum of 1929
B. Minimum water-level condition at well MA-FSW 760-0018 (7/19/2016 22:00)

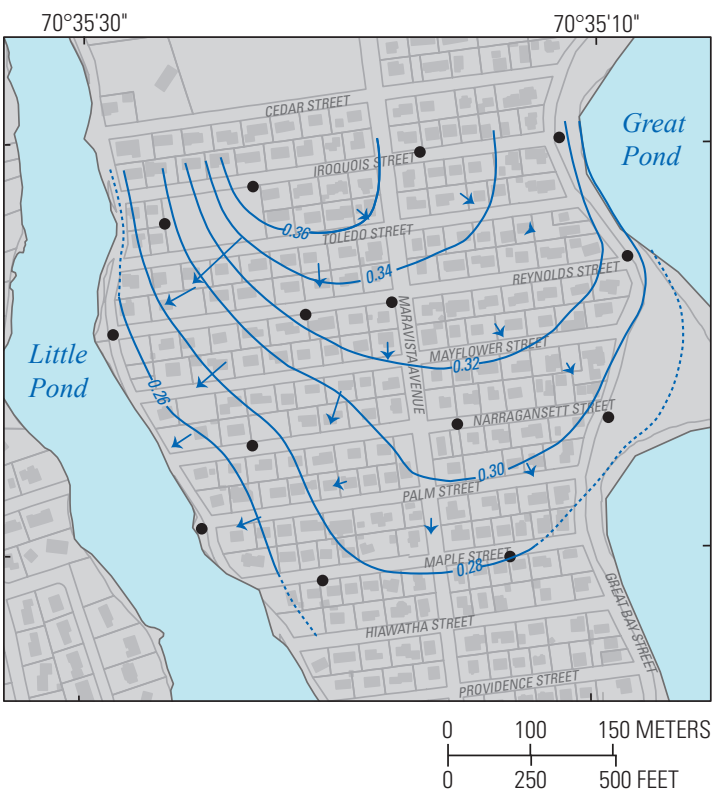

EXPLANATION

— $0.38 \ldots . .$. Water-level contour-Dashed where inferred. Contour interval is 0.02 meter. Datum is NGVD 29

Direction and magnitude of horizontal hydraulic gradient-Length of line is proportional to magnitude; magnitudes range from 0.000032 to 0.00059

- Monitoring well screened near the water table

Figure 6. Water-table altitude and hydraulic gradients, Maravista peninsula, East Falmouth, Massachusetts. $A$, maximum and $B$, minimum water-level conditions at site MA-FSW 760-0018. $C$, mean daily mean water levels from continuous water levels collected from June 27 to August 2, 2016.

or about $0.19 \mathrm{~m}$ above the local sea level. The thickness of the freshwater zone at site F761 predicted by the GhybenHerzberg relation is about $7.8 \mathrm{~m}$, about $1.5 \mathrm{~m}$ less than observed at this site $(9.3 \mathrm{~m}$, fig. 7$)$. In a flowing groundwater system, the Ghyben-Herzberg method should overpredict the thickness in areas of downward flow, such as near groundwater divides, and underpredict the thickness in areas of upward flow, such as near discharge boundaries. Various factors may contribute to the difference between the observed and predicted thickness, such as aquifer heterogeneity, the complex relation of tidal stages among the two ponds and Vineyard Sound, and the simplification of the mixing zone at the freshwater/saltwater boundary as an interface delineated by a $\mathrm{SpC}$ of $3,000 \mu \mathrm{S} / \mathrm{cm}$. The relatively good agreement, on the other hand, indicates that groundwater flow in the freshwaterflow system under the peninsula is predominantly horizontal and is mostly independent of the much larger inland regional groundwater-flow system. 


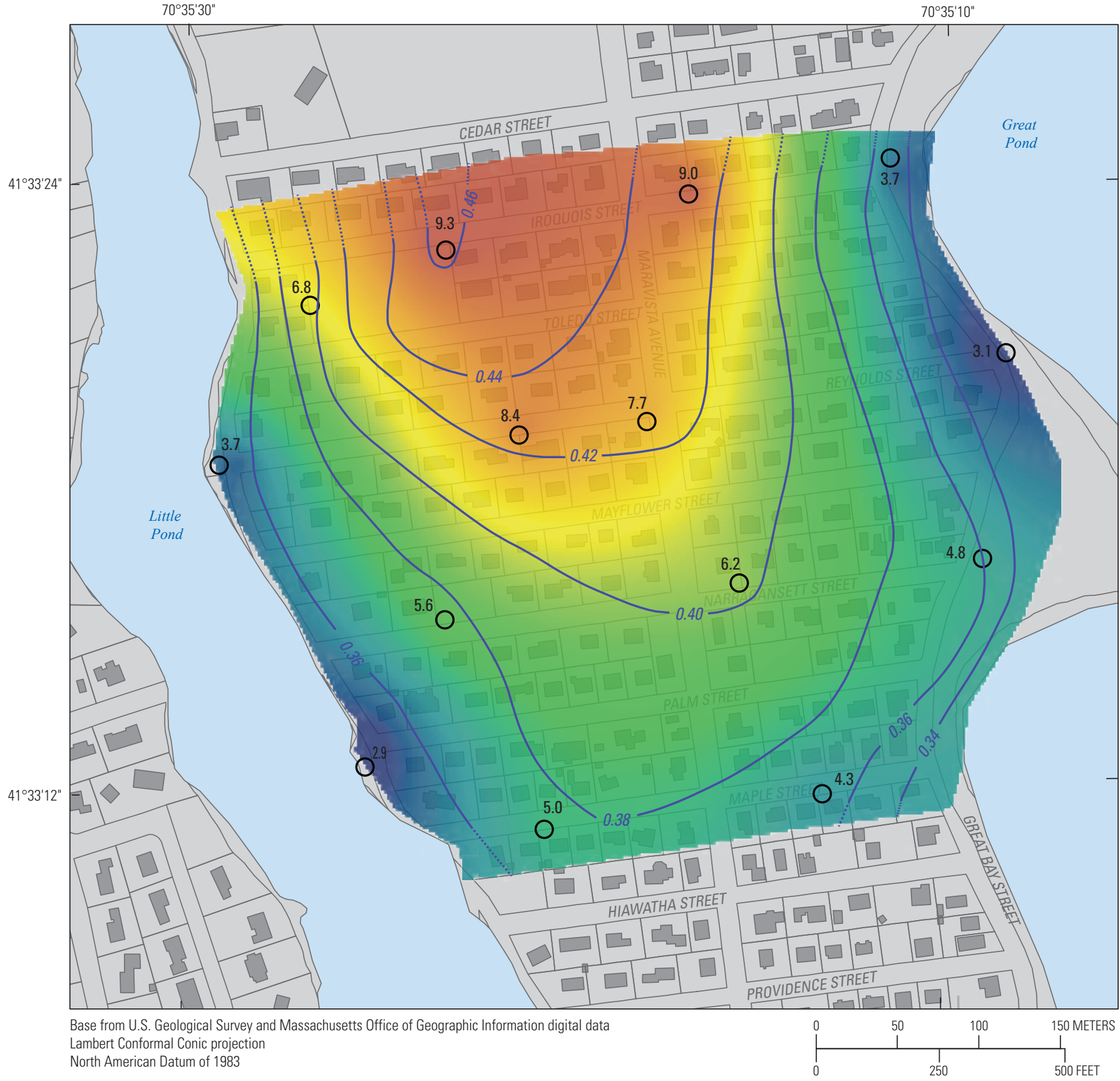

\section{EXPLANATION}

Thickness of fresh groundwater lens-

Determined by field measurements of specific conductance, June 2016, and mean daily mean water-level altitudes for period between June 27 and August 2, 2016

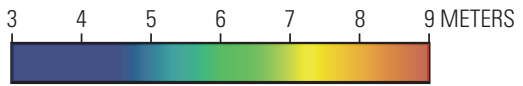

-0.38- Water-level contour-Dashed where inferred. Contour interval is 0.02 meter. Datum is NGVD 29

${ }^{6.8}$ Multilevel sampler location and

Figure 7. Freshwater thickness beneath the study area on Maravista peninsula, East Falmouth, Massachusetts. The thickness of the fresh groundwater lens was determined by using field measurements of specific conductance in June 2016 and mean water-table altitudes for the period from June 27 to August 2, 2016. Specific conductance less than 3,000 microsiemens per centimeter was considered freshwater. 


\section{Groundwater Traveltime}

An estimate of groundwater traveltimes - the groundwater residence times between recharge and discharge points-is necessary for the assessment of the arrival times of waterquality changes at the coast after wastewater disposal to the aquifer ends and expected improvements in the water quality of the coastal ponds begin. Groundwater traveltimes in the freshwater lens vary spatially and temporally and depend on hydrogeologic characteristics that include the recharge rate, hydraulic conductivity, effective porosity, and hydraulic properties at the discharge boundaries.

Given the estimated values from this study of hydraulic conductivity (from grain-size analysis of sediment cores, table 2), hydraulic gradient (from the water-table maps, fig. 6), and effective porosity (0.39 from Garabedian and others, 1991), estimated average linear groundwater velocities in the study area range from 0.028 to $0.163 \mathrm{~m} / \mathrm{d}$. These velocities are consistent with those estimated for a nearby coastal peninsula (Colman and others, 2018) and lower than those estimated for inland areas on Cape Cod, which generally are $0.3-0.6 \mathrm{~m} / \mathrm{d}$ (LeBlanc, 1984). The average linear groundwater velocity for the average of the estimated hydraulic conductivities $(69 \mathrm{~m} / \mathrm{d})$ from the four sediment cores and hydraulic gradients representative of the study area $(0.00043-0.00054)$ is about $0.076-0.096 \mathrm{~m} / \mathrm{d}$.

The traveltime along a horizontal flow path perpendicular to the water-table contours from site F760 to Little Pond (figs. 2 and 6) is estimated to be 5.2-6.4 years. Groundwater traveltimes along flow paths from the groundwater divide near Maravista Avenue to Little Pond are estimated to be 7.8-9.7 years (for the average hydraulic conductivity value of $69 \mathrm{~m} / \mathrm{d}$ ). These estimates assume that the flow paths are shallow and horizontal. Hydraulic heads at the paired shallow and deep wells along section $A-A^{\prime}$ show slight downward gradients at inland sites and strong upward gradients near the coast, indicating that groundwater flow follows a path that is gently curved downward and then more steeply upward. The additional vertical component of flow would result in longer traveltimes than those estimated for strictly horizontal flow.

\section{Groundwater-Quality Results}

Detailed vertical profiles of groundwater chemistry in the Maravista study area were collected and compared for 3 years, including about 1 year before connections began (June 2016 to April 2017) and 2 years during the transitional phase as homes were connected to the new sewer system (April 2017 to June 2019, table 1). The results from four full waterquality sampling rounds (June 2016, April 2017, April 2018, and June 2019) and eight additional partial sampling rounds from at least two sites (September 2016, December 2016, March 2017, June 2017, September 2017, August 2018, February 2019, and September 2019) are available in the
USGS National Water Information System database (USGS, 2019) at https://doi.org/10.5066/F7P55KJN and tabulated in the USGS data release available at https://doi.org/10.5066/ P9GEMMN6 (McCobb and others, 2019). The methods of water-quality sample collection and analysis are documented in Savoie and others (2012) and the USGS National Field Manual (USGS, variously dated). All sampling was done according to a quality assurance project plan approved by the U.S. Environmental Protection Agency. Detailed descriptions of project-specific aspects of the water-quality sampling are provided in appendix 1.

The distributions of wastewater-related water-quality indicators, including $\mathrm{SpC}, \mathrm{pH}$, DO concentration, nitrogen species, boron, and chloride, and their variability before and during connection to the sewers were examined. The focus of the water-quality analysis was on nitrogen because of concerns about excessive loading to the coastal ponds and estuaries. Most of the nitrogen detected was in the form of nitrate, suggesting that ammonification and subsequent nitrification of the wastewater occurred in the septic systems and in the unsaturated zone before groundwater recharge. Trends in these observations and the resulting estimated rates of nitrate loading to Little Pond are presented, and expectations for trends after all homes are connected to the sewer system are discussed.

\section{Water-Quality Observations}

Geochemical profiles of water quality from multilevel samplers (MLS) at 14 profile sites in the study area and at 1 reference profile site (site F724) in a nearby densely developed coastal neighborhood (fig. 1) are presented in appendix 1. Samples were analyzed for field water-quality characteristics and concentrations of nutrients and major ions. Selected analytes and number of samples by round are presented in table 1. Samples collected from the MLS provide detailed vertical profiles (as many as 15 sampling ports) of geochemical conditions that represent groundwater recharged at locations at different distances upgradient from the MLS.

\section{Field Properties}

Physiochemical field measurements can provide evidence of human influence, such as wastewater input and application of deicing salt, on groundwater quality, and can show the depth of saline groundwater and extent of mixing with fresh groundwater. The physical property of $\mathrm{SpC}$, and chemical properties, including $\mathrm{pH}$ and DO concentration, were measured to provide general indicators of geochemical conditions in groundwater in the study area.

$\mathrm{SpC}$ is a measure of water's ability to conduct an electrical current at 25 degrees Celsius and is related to the amount and mobility of dissolved ions in water. Because wastewater increases dissolved-ion concentrations in groundwater, $\mathrm{SpC}$ can be a useful measure of wastewater-impacted groundwater and the presence of seawater (LeBlanc 1984; Hem, 1985). As 
described in the "Freshwater/Saltwater Boundary" section, $\mathrm{SpC}$ was used to delineate the freshwater/saltwater boundary at the 15 sampling sites. In the freshwater zone, defined for this study as $\mathrm{SpC}<3,000 \mu \mathrm{S} / \mathrm{cm}, \mathrm{SpC}$ ranged from 41.8 to $2,990 \mu \mathrm{S} / \mathrm{cm}$, and mean and median values were 287 and $198 \mu \mathrm{S} / \mathrm{cm}$, respectively. At most of the locations, the lowest $\mathrm{SpC}$ values were measured in the shallowest sampling port near the water table where recently recharged water from precipitation is low in solutes. Groundwater profiles from 13 of the 15 sites consistently exhibited monotonically increasing values of $\mathrm{SpC}$ with increasing depth.

The $\mathrm{pH}$, the measure of hydrogen-ion activity in a solution and a primary factor governing groundwater geochemistry (USGS, variously dated), ranged from 4.26 to 6.44 standard units in the fresh groundwater, and the mean and median values were 5.15 and 4.99 standard units, respectively. The saline groundwater generally had a slightly higher, less acidic $\mathrm{pH}$ (mean was 5.42 standard units) because of an increase in total dissolved solids.

Shallow groundwater near the water table typically had high DO concentrations (greater than (>) $5 \mathrm{mg} / \mathrm{L}$ ), except at site F770, near the shore of the Little Pond, and at the reference site (F724). The mean and median concentrations of DO from the profile samples $(n=761)$ were 2.96 and $1.90 \mathrm{mg} / \mathrm{L}$, respectively. Most of the groundwater profiles included intervals of suboxic $(0.02-0.1 \mathrm{mg} / \mathrm{L})$ and anoxic $(<0.02 \mathrm{mg} / \mathrm{L})$ DO conditions, often occurring deeper in the bottom one-half of the freshwater zone and uniformly in saline groundwater. Low DO concentrations in the freshwater zone usually coincided with intervals of slightly elevated $\mathrm{SpC}$ and dissolved-inorganic nitrogen concentrations. DO concentrations exhibited more variability over time as compared to $\mathrm{SpC}$ and $\mathrm{pH}$. The $\mathrm{DO}$ variability was generally associated with the temporal changes in dissolved inorganic nitrogen concentrations.

\section{Nutrients}

Concentrations elevated above typical, uncontaminated fresh groundwater in the Cape Cod aquifer of dissolvedinorganic nitrogen, including nitrate plus nitrite, nitrite, and ammonium, were detected in all 15 groundwater profiles and for all sampling rounds. The most common form of groundwater nitrogen in the study area is nitrate. Concentration of nitrate plus nitrite $\left(\mathrm{NO}_{3}+\mathrm{NO}_{2}\right)$ is reported as milligrams per liter nitrate-nitrogen $\left(\mathrm{NO}_{3}-\mathrm{N}\right)$ unless noted otherwise because nitrite concentrations were usually small (mean $<0.004 \mathrm{mg} / \mathrm{L}$ as nitrogen $[\mathrm{N}]$ ). Nitrate concentrations in the freshwater zone ( $n=749)$ as high as $26.2 \mathrm{mg} / \mathrm{L}$ as $\mathrm{N}$ were measured, and mean and median values were 5.1 and $4.1 \mathrm{mg} / \mathrm{L}$ as $\mathrm{N}$, respectively. The highest nitrate concentrations typically were deeper in the freshwater zone (appendix 1). The vertical location of the highest concentrations in each profile, as a ratio of depth below the water table to freshwater thickness, averaged 0.74 . Four sites (F761, F766, F767, and F768, fig. 2) intermittently exhibited multiple intervals of elevated nitrate, both shallow near the water table and deeper in the freshwater zone.
Elevated nitrate concentrations typically were associated with elevated $\mathrm{SpC}$ and lower $\mathrm{pH}$ and were present more frequently in intervals with low DO concentrations.

The pattern of vertical distributions of nitrate can generally be related to the thickness of the freshwater zone. Nitrate was present over broad continuous vertical intervals at most sites near the center of the peninsula where the freshwater zone is thickest (sites F757, F761, F762, F760, F765, F768, and F724). Nitrate at sites where the freshwater zone is thin tended to have discrete intervals of elevated nitrate that varied over time in thickness and vertical location. Sites along the northern boundary of the study area where the freshwater zone was thickest (F757, F761, F762, fig. 2) consistently exhibited elevated nitrate concentrations under oxic conditions within $1 \mathrm{~m}$ of the water table and under suboxic conditions deeper in the zone. The two zones of elevated nitrate concentrations likely reflect the influence of nearby and more distant sources of recharge.

The thickness-weighted mean and maximum nitrate concentrations (methodology described in appendix 1) for the MLS profiles were generally consistent at a given site through the presewering (June 2016 and April 2017) and transitional period (April 2018 and June 2019) full sampling rounds (fig. 8). Nitrate concentrations greater than $10 \mathrm{mg} / \mathrm{L}$ as N, the U.S. Environmental Protection Agency maximum contaminant level for nitrate in drinking water, were detected at 9 of the 14 sites, as well as at the reference site (F724). At eight sites, including the reference site, the average of the mean thicknessweighted nitrate concentrations for the four full sampling rounds was $>5.0 \mathrm{mg} / \mathrm{L}$ as $\mathrm{N}$, and $>8 \mathrm{mg} / \mathrm{L}$ as $\mathrm{N}$ at three sites (F760, F724, and F772).

The total mass of nitrate at a profile location can be estimated from the mean nitrate concentrations for a unit area such as one square meter. This approach indicates the total mass present at the location that is independent of the thickness of the freshwater zone at that location. The total mass of nitrate as $\mathrm{N}$ at the 15 sites sampled during the four full sampling rounds ranged from 1,830 to 36,800 milligrams as nitrogen per square meter of land surface. The largest nitrate mass was at the reference site (F724), where high nitrate values were detected over a 12-m-thick freshwater zone, which is significantly thicker than the freshwater zone at the Maravista peninsula. The largest nitrate mass in the study area $(>10,000$ milligrams as nitrogen per square meter) was at sites with high nitrate concentrations over thick $(>4.5 \mathrm{~m})$ freshwater zones (F760, F772, F765, F761, F768, and F769) (fig. 8).

Ammonium concentrations as high as $5.7 \mathrm{mg} / \mathrm{L}$ as N were measured in freshwater at 13 of the 15 sites, including the reference site. Ammonium concentrations regularly exceeded $1 \mathrm{mg} / \mathrm{L}$ as $\mathrm{N}$ at multiple sampling ports at site F760, and the highest concentrations were detected within $2 \mathrm{~m}$ of the water table. Otherwise, ammonium concentrations above the detection limit were measured infrequently and mostly in the deeper, anoxic freshwater zone. Elevated ammonium concentrations were regularly detected in saline groundwater. 

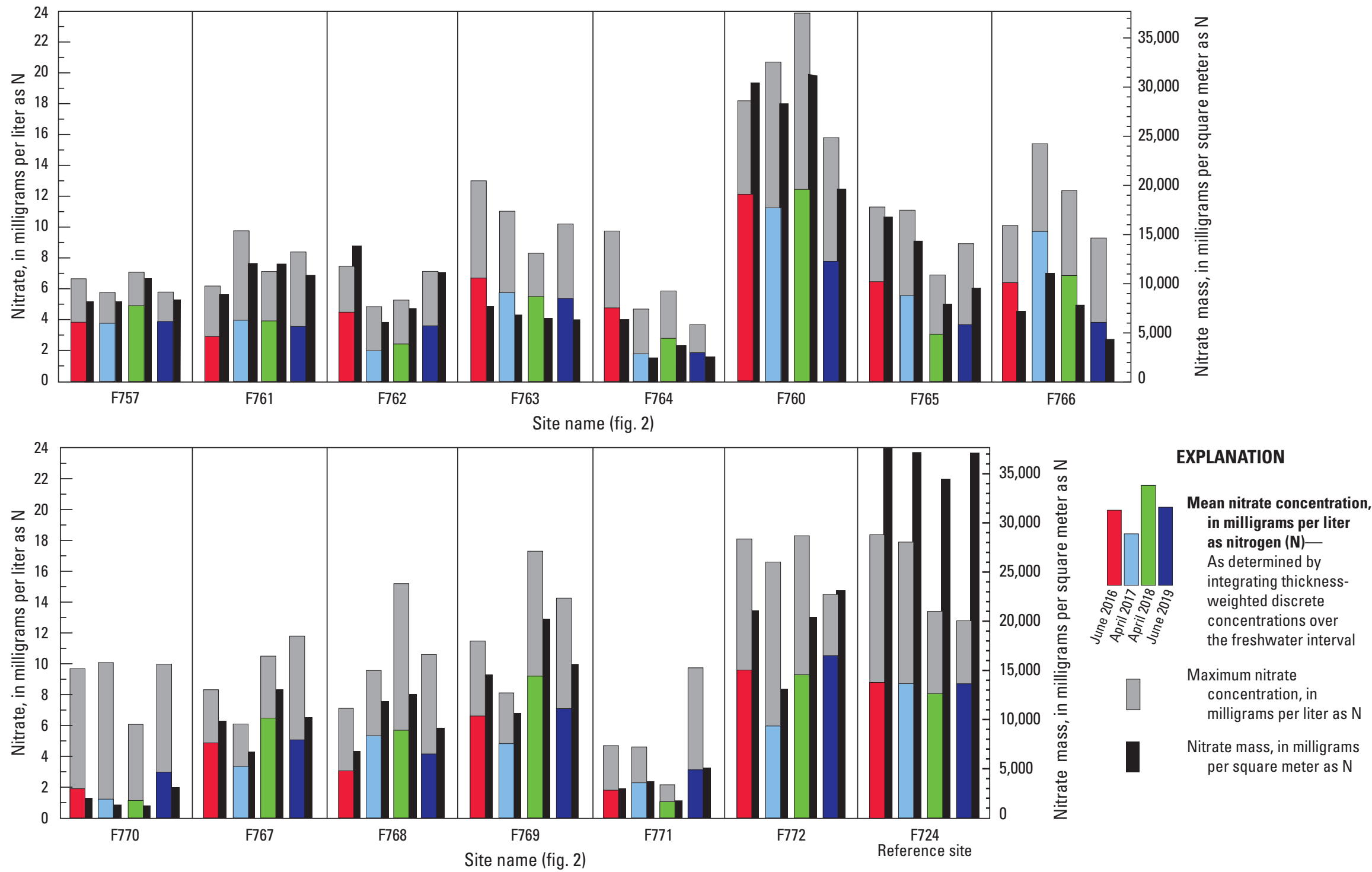

EXPLANATION

Figure 8. Maximum and thickness-weighted mean nitrate concentrations and total nitrate mass per square meter of land area at 15 vertical-profile locations for full sampling rounds in June 2016, April 2017, April 2018, and June 2019, Maravista peninsula, East Falmouth, Massachusetts. 
Total nitrogen (TN) and total phosphorus concentrations were determined for a subset of 45 freshwater samples collected at eight sites in September 2016. Total organic nitrogen, calculated as the difference between $\mathrm{TN}$ and total inorganic nitrogen (TIN), ranged from 0 to $2.05 \mathrm{mg} / \mathrm{L}$ as $\mathrm{N}$, or on average, 11.3 percent of the TN. Calculated organic nitrogen in the freshwater port at $-9.5 \mathrm{~m}$ altitude at site $\mathrm{F} 769$ was $33.4 \mathrm{mg} / \mathrm{L}$ as $\mathrm{N}$, resulting from an anomalously high total nitrogen value of $45.3 \mathrm{mg} / \mathrm{L}$ as $\mathrm{N}$. Total phosphorus concentrations were greater than the detection limit in only 3 of the 45 samples, and the maximum value was $0.17 \mathrm{mg} / \mathrm{L}$ as phosphorus.

Although not examined as part of this study, the potential for reduction of nitrogen through denitrification and anaerobic ammonium oxidation, or anammox, is evident in the geochemical profiles. As described by Colman and others (2018) for observations made during their study at the reference site (F724), nitrogen reduction is favored in shallow vertical intervals with low DO concentrations and sufficient reactive electron donors (such as organic carbon), as well as at the deep freshwater/saltwater boundary where freshwater containing nitrate mixes with saltwater containing high organic carbon. Additional data on nitrate reduction indicators, such as excess nitrogen gas, would be needed to determine whether nitrate reduction is occurring in geochemically favorable zones in groundwater in the study area.

\section{Other Inorganic lons}

Several other inorganic ions, in addition to nitrogen and phosphorus, have been good indicators of wastewater-affected groundwater. These include but are not limited to boron, chloride, sodium, potassium, and dissolved carbon (LeBlanc, 1984; Robertson and others, 1991; Colman and others, 2018).

Concentrations of boron and chloride in groundwater in the study area differed greatly between the freshwater and saltwater zones. Saline water, as indicated by $\mathrm{SpC}>3,000 \mu \mathrm{S} / \mathrm{cm}$, had mean boron and chloride concentrations of 2,030 micrograms per liter and $11,600 \mathrm{mg} / \mathrm{L}$, respectively. In the freshwater zone, boron concentrations from 150 samples (mean was 39.6 micrograms per liter) collected in June 2016 were positively correlated to nitrate concentrations (fig. 9), indicating that boron can be a useful tool in the study area as an indicator of wastewater.

Chloride concentrations at low values not associated with saline groundwater also were positively correlated with nitrate but to a lesser degree than boron (data not shown). The association was not solely indicative of wastewater effects. For example, water-quality profiles at site F760 in June 2016 show monotonically increasing chloride with increasing depth, and the highest freshwater concentrations deeper in the system were coincident with the highest TIN intervals (fig. 10A). Elevated chloride also was detected in the shallowest sampling port where little or no TIN was detected. The distribution of boron in the deeper part of the profile matched the distribution of nitrate closely. In contrast, chloride concentrations at site F768 were elevated throughout the freshwater zone at concentrations ranging from 42 to $156 \mathrm{mg} / \mathrm{L}$ (app. 1 , fig. $1.1 \mathrm{~K}$ at the back of the report). The freshwater zone at this site was characterized by high SpC (179-781 $\mu \mathrm{S} / \mathrm{cm})$, moderate oxygen (3.0-6.4 mg/L), low to moderate TIN (1.5-3.0 mg/L as $\mathrm{N}$ ), and low boron (8-38 micrograms per liter). These characteristics suggest that applying road salt to the heavily travelled Maravista Avenue affects the site, which is directly downgradient from the road (fig. 2).

Analysis of other major ions, including the cations calcium and magnesium and anion fluoride, in samples collected at a subset of sampling ports in September $2016(n=30)$ also were correlated with TIN at many locations, similar to correlations reported by Colman and others (2018) at the reference site. Fluoride, an anion used in dental-related personal care products, seems to be correlated with nitrate at site F760, although the concentrations of fluoride are less than about $0.3 \mathrm{mg} / \mathrm{L}$ (fig. 10B).

Additional analysis of other ions, including boron, chloride, bromide, and fluoride, during future sampling rounds would enhance the understanding of water-quality changes after wastewater no longer recharges the groundwater and would provide information on the water-quality effects of other anthropogenic inputs (for example, deicing salt and fertilizer) that will continue in the coastal neighborhood.

\section{Observed Trends in Water-Quality}

The variability of nitrate concentrations for the two sampling periods (June 2016 and April 2017) before connection to the sewers began and the two transitional sampling

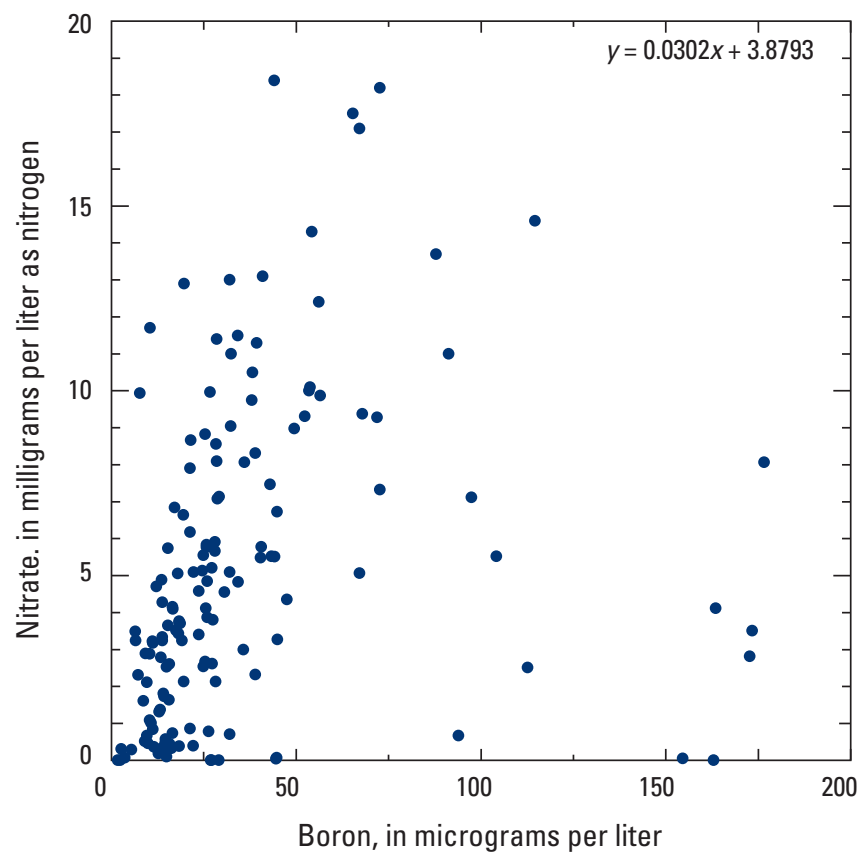

Figure 9. Comparison of concentrations of nitrate and boron for 150 samples collected from wells screened in freshwater, June 2016, Maravista peninsula, East Falmouth, Massachusetts. 
A

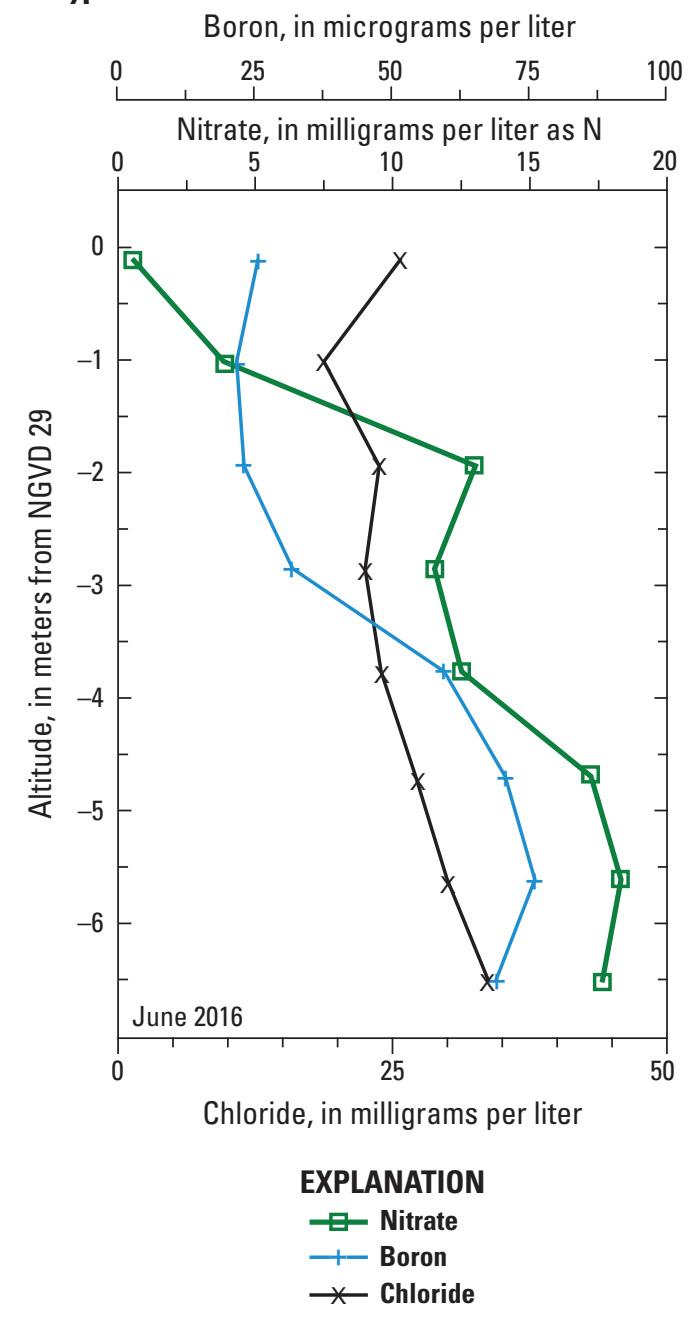

$B$
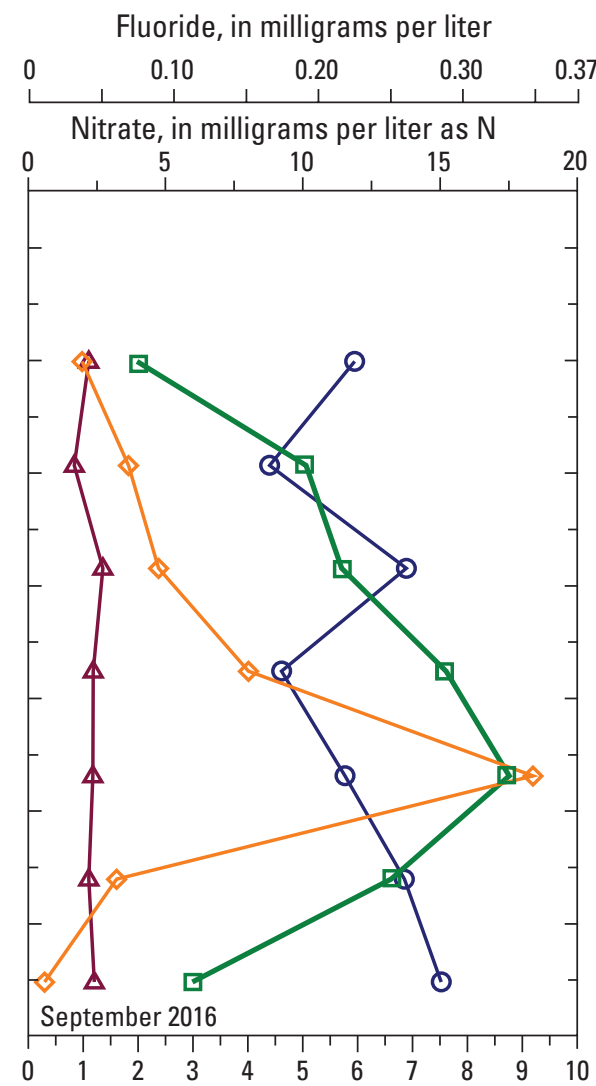

Calcium or magnesium, in milligrams per liter

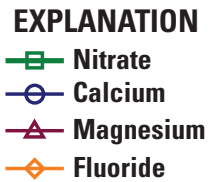

Figure 10. Vertical water-quality profiles of inorganic ions at site MA-FSW 760-M01, Maravista peninsula, East Falmouth, Massachusetts. $A$, nitrate, boron, and chloride in June 2016. $B$, nitrate, calcium, magnesium, and fluoride in September 2016.

periods (April 2018 and June 2019) is clear in the thicknessweighted mean and maximum concentrations and vertically integrated total mass of nitrate over time at the 15 profile sites (fig. 8). Between June 2016 and April 2017, during the period before connections began, 11 of 15 sites (including the reference site) had on average a decrease in mean concentrations of $0.45 \mathrm{mg} / \mathrm{L}$ as N. The sampling event in April 2018, shortly after the start of the transition period, showed a mixture of changes to mean concentrations at the profiles; the mean increased at eight sites (change to mean was $+1.87 \mathrm{mg} / \mathrm{L}$ as N) and decreased at seven sites (change to mean was $-1.10 \mathrm{mg} / \mathrm{L}$ as $\mathrm{N}$ ). The mean concentrations decreased at 9 of the 15 profiles during the July 2019 sampling round at the end of the transition period (change to mean was $-1.69 \mathrm{mg} / \mathrm{L}$ as $\mathrm{N}$ ).

More frequent sampling was done at two sites (F760 and F767) to assess temporal variability in nitrate concentrations. The results show mixed trends during 2016-19. At F760, mean and maximum nitrate concentrations observably decreased starting early in the sewer-connection period (spring 2017) (fig. 11). Mean and maximum concentrations at F760 decreased by 69.5 and 51.6 percent, respectively, between June 2017 and September 2019. This decrease was accompanied by small increases in dissolved oxygen and $\mathrm{pH}$ and by a decrease in SpC. These changes occurred throughout the freshwater zone, particularly in the deeper zone of high nitrate concentrations. This zone is presumably along a longer groundwater flow path than the shallower groundwater. In contrast, at site F767, the mean and maximum nitrate concentrations over the profile increased by 16.5 and 53.4 percent, respectively, over the same period, demonstrating that the timing of water-quality changes at any one site depends on the timing of conversion from septic systems to sewers at sites upgradient from the sampled location, and on proximity and locations of upgradient systems along flow paths to the sampled site. 


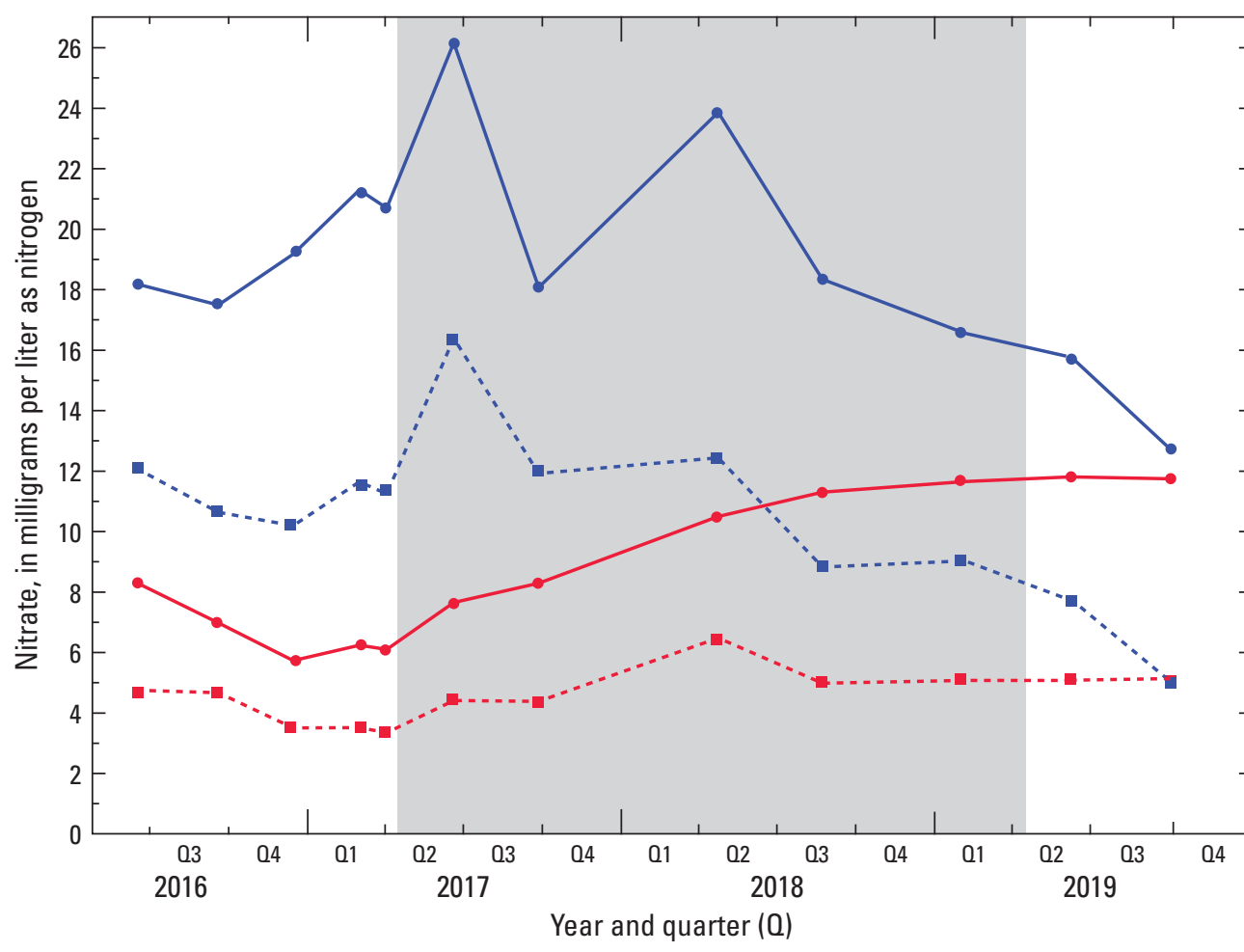

\section{EXPLANATION}

Sewer connection period F760

$\rightarrow$ Maximum

-.-.-. Mean

F767

$\longrightarrow$ Maximum

--1-. Mean

Figure 11. Maximum and mean nitrate concentrations for vertical water-quality profiles at two multilevel sampler sites (MA-FSW 760M01 and MA-FSW 767-M01) between June 2016 and September 2019, Maravista peninsula, East Falmouth, Massachusetts.

A statistical assessment was conducted with the modified Regional Kendall test (Helsel and Frans, 2006) to determine if there were temporal trends in the concentrations of selected constituents. The magnitude of the change in concentration over time was estimated (Sen, 1968), and trends determined at the probability value (called a " $p$-value") $<0.05$ level were considered statistically significant. Because vertical variations in water quality reflect primarily horizontal groundwater flow paths of various lengths, the trends were analyzed for vertically grouped concentrations. The thickness of the freshwater zone at each sampled site was divided into 10 depth groups by fraction of the freshwater thickness at each site. The sampling ports at all the sites were then assigned to the groups depending on their fractional depth at their site.

The summary statistics of trends in nitrate, dissolved oxygen, and specific conductance for each depth group are presented in table 3. Only the 0.4 depth group showed a statistically significant trend in all three water-quality characteristics over the 3-year period that encompassed the transition from septic systems to the sewer system. For the 0.4 depth group during this period, nitrate concentration ( -0.76 milligram per liter per year) and specific conductance $(-12.1$ microsiemens per centimeter per year) decreased and dissolved-oxygen concentration ( 0.82 milligram per liter per year) increased. The well screens and MLS ports in this depth group are from 1.0 to $3.4 \mathrm{~m}$ below the water table (freshwater normalized depth range from 0.31 to 0.39$)$. Nitrate concentrations in the depth groups directly above $(0.3)$ and below $(0.5-0.6)$ the
0.4 depth group also decreased more than 0.15 milligram per liter per year during the 3-year period, but the changes were not statistically significant. Nitrate concentrations increased in the shallowest depth interval (0.1) and at two deeper intervals $(0.8-0.9)$ but at rates that were not statistically significant. Possible causes for the differences with depth in the observed trends are discussed in the "Expected Trends in Water Quality" section.

\section{Estimated Nitrate Mass Flux Toward Little Pond}

The goal of the municipal sewer connections in the neighborhood is to reduce nitrogen loading to Little Pond. Nitrate mass flux toward Little Pond (also referred to as nitrate load) was estimated using temporal concentration data and estimates of volumetric groundwater flow through section $B-B^{\prime}$, a 500 -m-wide vertical section upgradient from Little Pond. The section extends from just north of site F757, through sites F764 and F767, to just south of site F771 (fig. 2). The estimates represent instantaneous mass loads for each of the four full sampling rounds (June 2016, April 2017, April 2018, and June 2019, table 1) and the range of hydraulic gradients observed during the study period. Because of tidal effects apparent in the discrete water-level measurements made during the full sampling rounds, which each took several days and, therefore, extended over multiple tidal cycles, accurate estimates of hydraulic gradients could not be made 
Table 3. Summary statistics by depth group from the modified Regional Kendall analysis for water samples collected in June 2016, April 2017, April 2018, and June 2019.

[Bold values indicate statistically significant results with a probability value (p-value) less than 0.05 ; No., number; MLS, multilevel sampler]

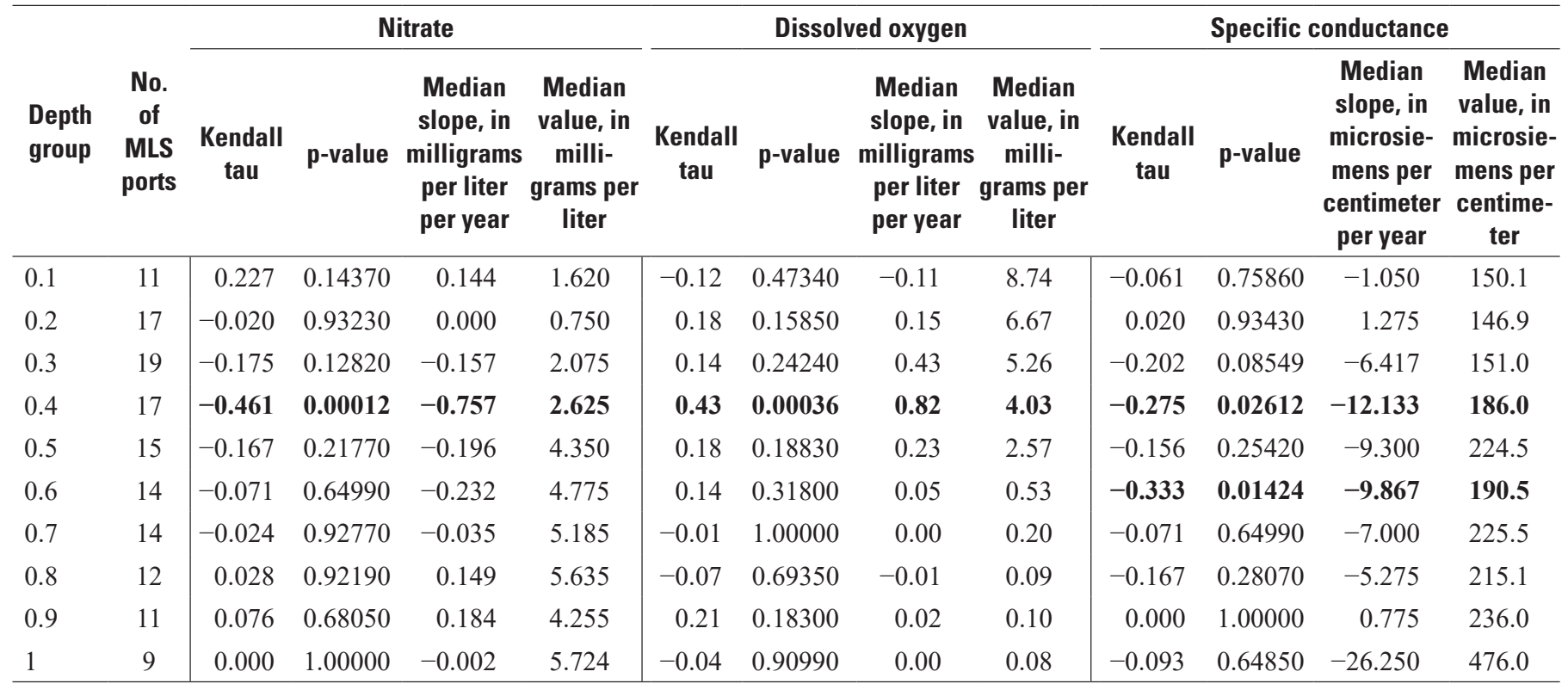

using the water-table snapshots. Instead, three water-level conditions identified from continuous water-level records collected between June 27 and August 2, 2016, as described in the "Hydraulic Heads and Gradients" section (figs. $6 A-C$ ), were used for the mass-flux calculations. The calculation methods and assumptions are described further in appendix 1. In general, the concentration data and groundwater fluxes were distributed onto a two-dimensional vertical grid of cells aligned along section $B-B^{\prime}$ (figs. $12 A$ and $B$ ). The concentration field was developed from interpolated concentration contours that were rasterized to a finely spaced grid and then populated to the vertical grid as area-weighted mean values (fig. 12A). Volumetric groundwater flows for the four columns of cells along the section for each water-level condition were calculated by applying Darcy's Law and constant values for each column of the hydraulic gradients and estimated hydraulic conductivity (fig. 12B).

As an example, the vertical distribution of the calculated nitrate mass flux along section $B-B^{\prime}$ for the nitrate concentration measured in June 2016 and the water-table map of the mean of the daily mean water levels (fig. $6 \mathrm{C}$ ) are shown in figure $12 C$. The calculated nitrate fluxes from the four sampling rounds using average hydraulic gradients for the three water-level regimes range from 124.3 to 192.6 kilograms per year (table 4). The standard deviation for each sampling date of the calculated fluxes by water level condition ranged from 7.8 to 10.8 kilograms per year, which is small compared to the total nitrate fluxes for each date. Therefore, the variability in nitrate mass flux (the highest and lowest nitrate fluxes were in April 2018 and April 2017, respectively) mostly reflect the variability in the concentration fields over time. No clear decline in nitrate mass flux through the section in response to gradual connection to the sewers during April 2017 to June 2019 was evident. It is likely that water-quality changes after connection of most homes have not arrived yet at the section line near Little Pond.

Nitrate mass flux through section $B-B^{\prime}$ captures only part of total nitrogen flux to Little Pond. Section $B-B^{\prime}$ covers about 15 percent of the total shoreline that contributes groundwater to the pond. The estimate from the Massachusetts Estuaries Project of total attenuated nitrogen load to Little Pond based on 2009-10 data is 7,569 kilograms per year (CCC, 2017; Massachusetts Department of Environmental Protection, 2008). The low total nitrate flux through section $B-B^{\prime}$, as a proportion of total length of the pond shoreline, reflects the difference between the low hydraulic gradients, and therefore low groundwater flux, on the peninsula, and the higher hydraulic gradients on the western side and northern end of Little Pond reported by Millham and Howes (1994). Nitrate mass flux estimates from concentrations determined during future sampling rounds could be a valuable metric to extrapolate load reductions over time to Little Pond in response to the replacement of septic systems by the municipal sewers. 
A. Nitrate concentration

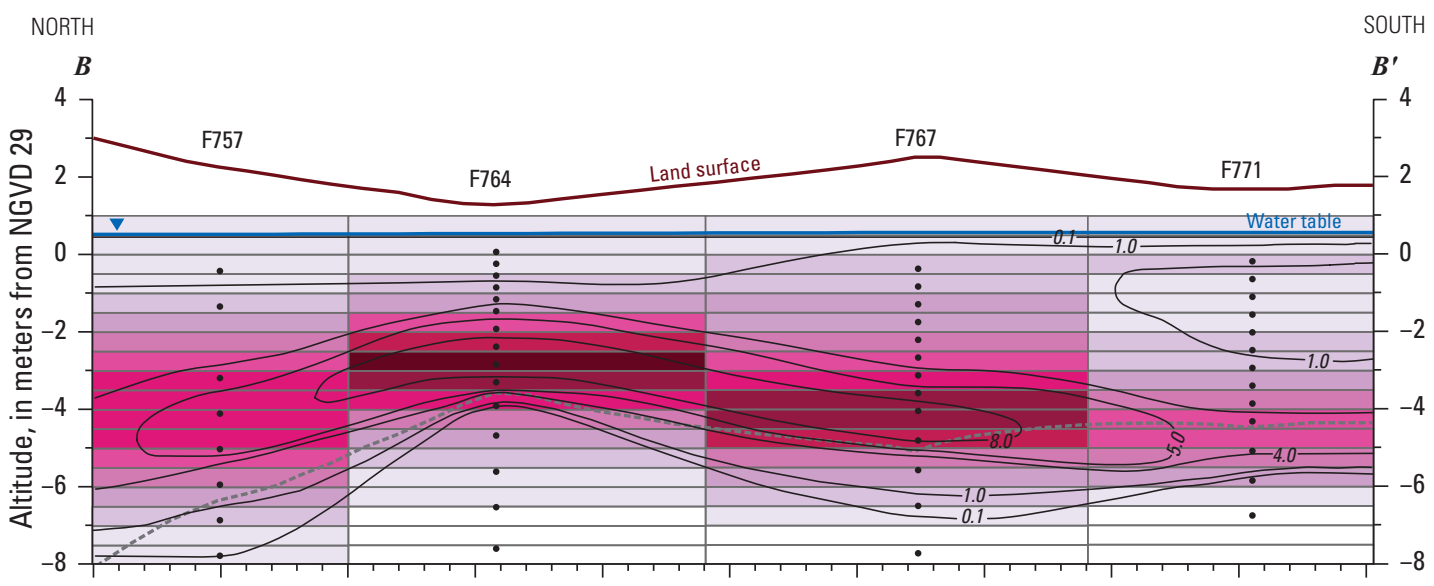

B. Groundwater flux

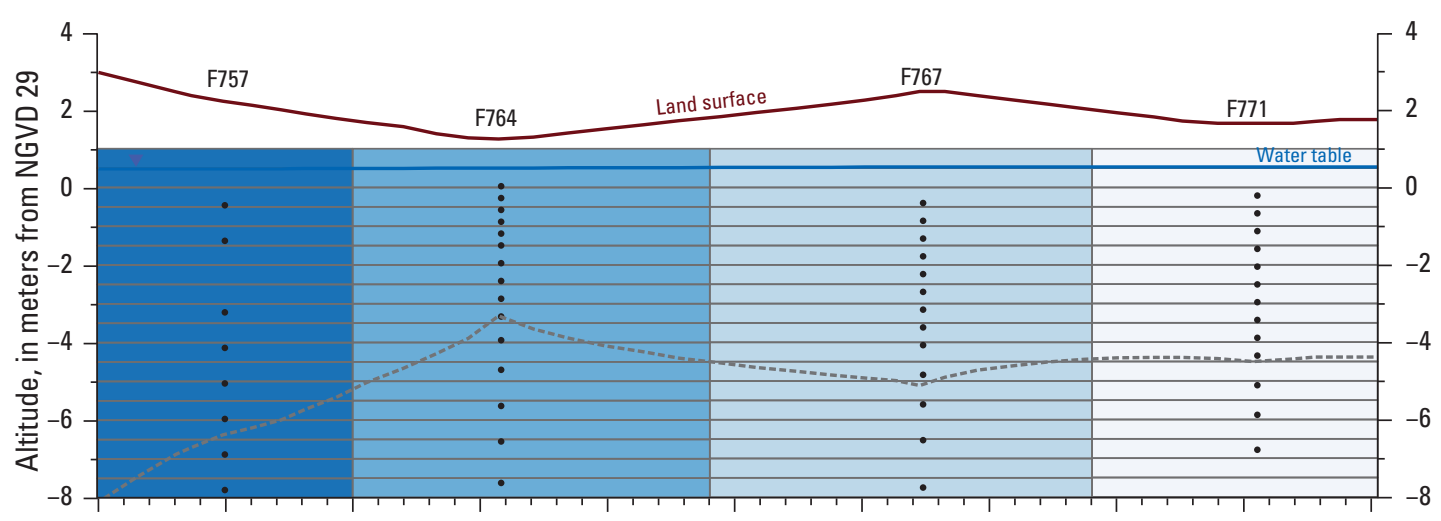

C. Nitrate mass flux

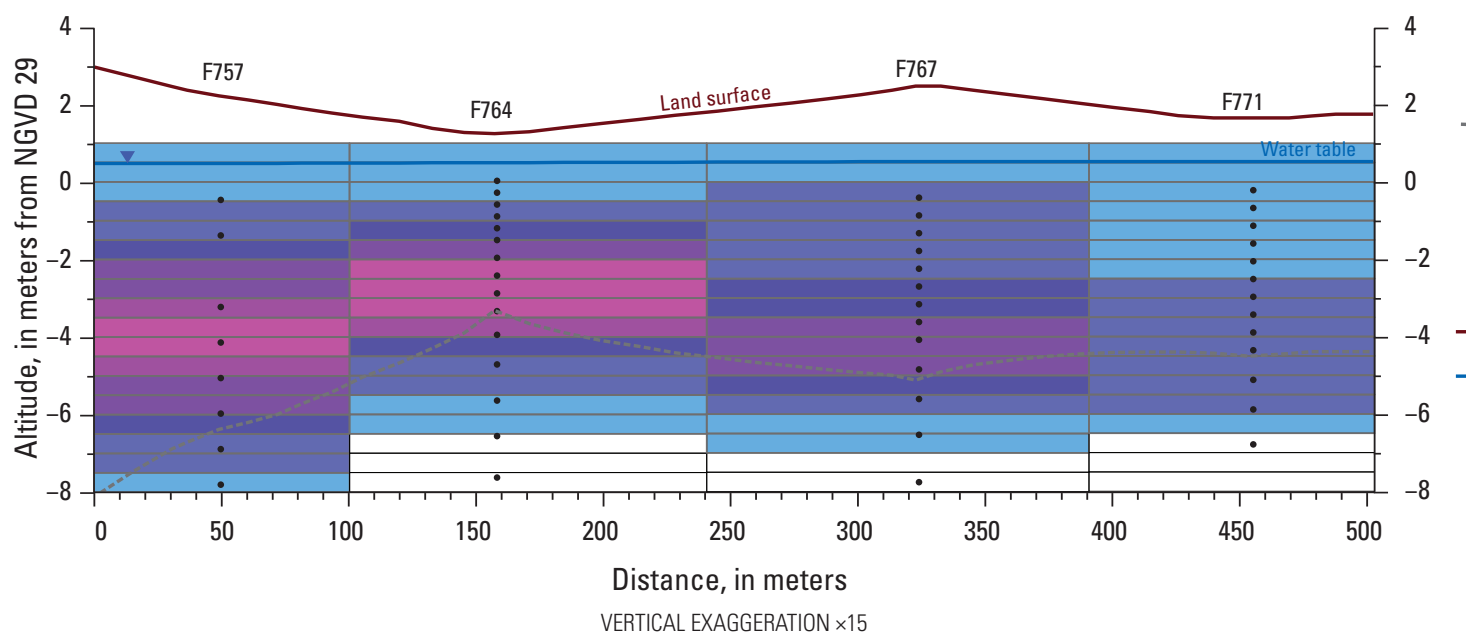

\section{EXPLANATION}

Nitrate concentration, in milligrams per

liter as nitrogen

$<0.1$

0.1 to $<1.0$

1.0 to $<2.0$

2.0 to $<3.0$

3.0 to $<4.0$

4.0 to $<5.0$

5.0 to $<6.0$

6.0 to $<7.0$

7.0 to $<8.0$

8.0 to $<9.0$

Flow, in cubic meters per day

$\square \quad 1.70$

$\square \quad 2.23$

$\square \quad 3.57$

4.55

Nitrate mass flux, in kilograms per year 0

$\square>0$ to $<1.0$

1.0 to $<3.0$

3.0 to $<5.0$

5.0 to $<7.0$

7.0 to $<9.0$

9.0 to $<11.0$

$-1.0-$ Line of equal nitrate concentrationDashed where inferred. Contour interval varies. Samples collected in June 2016

---- Line of specific conductance value of 3,000 microsiemens per centimeter at 25 degrees Celsius

- Land surface

- Water table

- Sampling port

Figure 12. Distributions of nitrate, groundwater flux, and nitrate mass flux through section $B-B^{\prime}$, Maravista peninsula, East Falmouth, Massachusetts. $A$, nitrate concentration in June 2016. $B$, groundwater flux, determined using hydraulic gradients from mean daily mean water levels for the period between June 27 and August 2, 2016. C, nitrate flux in June 2016. 
Table 4. Summary of calculated nitrate mass flux through section $B-B^{\prime}$ for four sampling rounds using hydraulic gradients from various water-table conditions, Maravista peninsula, East Falmouth, Massachusetts, June 2016 to June 2019.

[Four groundwater flux zones were used per estimate as described in appendix 1. Location of section $B-B^{\prime}$ is shown in figure 2 . F760 is shorthand for well MA-FSW 760-0018; N/A, not applicable]

\begin{tabular}{|c|c|c|c|c|c|}
\hline \multirow{2}{*}{ Hydraulic gradient ${ }^{1}$ condition statistic $^{-}$} & \multirow{2}{*}{ Condition date and time } & \multicolumn{4}{|c|}{ Estimated nitrate mass flux, in kilograms per year } \\
\hline & & June 2016 & April 2017 & April 2018 & June 2019 \\
\hline Maximum water level at F760 & 7/11/2016 0:00 & 157.9 & 116.1 & 188.6 & 155.5 \\
\hline Mean daily mean water levels for all sites & $6 / 27 / 2016-8 / 2 / 2016$ & 177.1 & 136.5 & 203.8 & 163.7 \\
\hline Mean & $\mathrm{N} / \mathrm{A}$ & 165.3 & 124.3 & 192.6 & 155.8 \\
\hline
\end{tabular}

${ }^{1}$ Hydraulic gradients were determined using continuous water-level data collected between June 27, 2016, and August 2, 2016.

\section{Expected Trends in Water Quality}

The expected changes in groundwater water quality and associated decreased nitrogen loading to the coastal ponds after septic systems are replaced by municipal sewers depend on multiple factors. The rate of change reflects how quickly water is flushed from the aquifer - the residence time - which in turn is related to groundwater travel time that is driven by recharge rates, aquifer hydraulic properties, and resulting hydraulic gradients. The removal of artificial recharge from septic-system discharges, estimated to be about 20 percent of the natural recharge rate from precipitation, is expected to slightly increase residence times in the aquifer as hydraulic gradients decrease in response to the lower total recharge rate and affect the position of the freshwater/saltwater boundary. After the wastewater source is removed, residual nitrogen in the unsaturated and saturated zones from the decommissioned systems could continue to provide nitrogen input to the groundwater system for some time. Apparent changes to nitrate concentrations in the study area could also be slowed by the inflow of legacy nitrogen from upgradient areas nearby on the peninsula and farther inland, the continued input of nitrogen from other sources (fertilizer, stormwater), mixing effects of natural hydrodynamic dispersion, which causes a "tailing" effect as contaminants flush from the aquifer, and the potential for sorbed ammonium to mineralize and nitrify to nitrate as oxygenated water enters historically anoxic zones.

The expected improvements in groundwater quality in the freshwater zone should be characterized by decreases in concentrations of dissolved TN and TIN and common ions such as boron, chloride, and fluoride (Repert and others, 2006; Mullaney, 2015). Changes in physiochemical properties are expected to include increased $\mathrm{pH}$ and dissolved oxygen concentrations and decreased $\mathrm{SpC}$. The changes are likely to be variable rather than uniform in space and time. Although septic systems are usually considered nonpoint sources that affect water quality at a regional scale, the scale of the Maravista study area is small, and hydraulic gradients are shallow. Therefore, contaminant plumes from individual systems may persist for some distance in the aquifer before adjacent plumes and interspersed uncontaminated waters are mixed by macrodispersion and temporally varying flow directions (Weiskel and Howes, 1992). The persistence of individual plumes may complicate the detection of overall spatial trends in water quality based on few point measurements at wells and MLS, particularly when made over a brief period such as 2 years of monitoring since connections to the sewers began on the Maravista peninsula.

The conceptual model of septic-system recharge assumes that septic-system wastewater at a given location enters the groundwater system, along with uncontaminated recharge water from precipitation, at the water table and stays above older wastewater-affected groundwater from upgradient areas. This conceptual model suggests that water-quality changes after connection to the sewers should occur first in the shallowest groundwater and then progress into the deeper zones. The statistically significant trend of decreased nitrate and increased dissolved oxygen concentrations (table 3 ) in the upper one-half of the freshwater zone partly supports this conclusion, although nitrate concentration increased in the shallowest vertical interval (trend was not statistically significant). One possible explanation is that water quality in the shallowest groundwater is more variable than deeper in the flow system because the effects of individual septic systems only recently or not yet decommissioned persist as areas of elevated nitrate at the water table. These possibly isolated but numerous shallow areas of elevated nitrate should diminish with time now that most homes are connected to the sewer system.

The rate of water-quality change deeper in the flow system should be slower than near the water table because the flow paths and, therefore, the flushing time, should be longer. In addition, nitrate concentrations are significantly elevated in the deeper freshwater at many locations on the Maravista peninsula (for example, site F760, figs. $10 A$ and $B$ ). Similar zones of elevated nitrate have been observed at other sites on coastal peninsulas in Falmouth (Colman and others, 2018). Colman and others (2018) hypothesized that plumes from individual septic systems may sink into the groundwater system owing to a density difference between the septic-system leachate 
and uncontaminated groundwater, especially on the coastal necks where horizontal hydraulic gradients and, therefore, groundwater-flow rates, are small. If this is the case, the end of density-driven downward movement of septic-system plumes to deeper flow paths could cause more rapid attenuation of nitrate concentrations along the deeper flow paths than might be expected based on the conceptual model.

The results presented in this report are based on observations made during the 2-year period of transition between septic systems and municipal sewers. Water quality is likely to continue to improve gradually now that wastewater disposal has ended. As time progresses, future observations should show the water-quality changes and also provide additional evidence for the key processes that control the progress and nature of the changes.

\section{Summary and Conclusions}

A study by the U.S. Geological Survey (USGS), in cooperation with the U.S. Environmental Protection Agency's Southeast New England Program, is in progress to evaluate the effects of replacement of septic systems with municipal sewers on groundwater quality beneath a densely developed coastal neighborhood in Falmouth, Massachusetts. The purpose of the study is to monitor changes in groundwater quality and hydrology on part of the Maravista peninsula in response to sewer installation. The municipal sewering is expected to reduce nitrogen in the Little Pond groundwater watershed. Reduction in excessive nitrogen loading to coastal embayments is needed to improve water quality and restore a healthy aquatic ecosystem. This report describes the monitoring well network, including well and multilevel sampler installation and sampling methods, and provides results and interpretation from hydrogeologic and water-quality monitoring conducted from June 2016 to September 2019 before, during, and after completion of replacement of the septic systems by connections to the sewer system.

In total, about 1,400 properties surrounding Little Pond were connected to an existing sewer system between spring 2017 and summer 2019. A groundwater monitoring network consisting of multilevel samplers (MLS) and shallow monitoring wells was installed in an area on Maravista peninsula encompassing about 230 homes, all served by septic systems and public water supply.

Sediment cores from four sites in the study area encountered fine-to-coarse well-sorted sands consistent with deltaic glaciolacustrine outwash deposits on Cape Cod. Specific conductance measurements from the initial sampling round in June 2016 that included all 210 MLS sampling ports indicated that the fresh groundwater lens beneath the study area was 2.9-9.3 meters thick. Mean daily mean water levels ranged from 0.32 to 0.46 meter above the National Geodetic Vertical Datum of 1929. The mean ranges of tides for a 36-day period in February-March 2016 for Little Pond and Great Pond were
0.126 and 0.468 meter, respectively; tidal response time at Little Pond was delayed by about 1.6 hours on average from that of Great Pond. Daily tidal water-level ranges in groundwater were measured at all well sites and on average ranged from 0.06 to 0.189 meter, and the greatest tidal influences were measured at sites nearest the coastal ponds.

The shallow groundwater-flow system is characterized by a groundwater divide slightly west of the center of the peninsula; its position varies during periods of high and low groundwater levels. The magnitude of hydraulic gradients in the study area, which also vary spatially and temporally, are very low, ranging from 0.000032 to 0.00059 . Estimates of average linear groundwater velocities upgradient from Little Pond obtained from observed hydraulic gradients and estimated aquifer hydraulic conductivity and effective porosity, range from 0.076 and 0.094 meter per day. Estimated groundwater traveltimes along shallow flow paths from the groundwater divide west to Little Pond range from 7.8 to 9.7 years, although traveltimes are expected to be longer on deeper flow paths that penetrate to near the bottom of the freshwater lens.

The full network of MLS was sampled four times between June 2016 and June 2019, a period that encompassed presewering and transitional periods. Two MLS sites were sampled seven additional times between June 2016 and September 2019 to better characterize temporal variability in water-quality indicators. Each sampling round included physiochemical field properties (specific conductance, dissolved oxygen, and $\mathrm{pH}$ ) and nitrogen species. Additional constituents, including total nitrogen, total phosphorus, and major ions were measured in September 2016 at selected sites. The first sampling round (June 2016) also included boron and chloride as indicators of wastewater-affected groundwater and to further delineate the freshwater/saltwater boundary in the subsurface. Boron concentrations in the freshwater zone (mean concentration was 39.6 micrograms per liter) were positively correlated to nitrate concentrations; freshwater chloride concentrations were less well correlated with nitrogen, perhaps because of the confounding effects on chloride concentrations from road salt.

Elevated nitrogen, as compared to typical uncontaminated, fresh groundwater in the Cape Cod aquifer, predominately as nitrate, was measured at all 15 sites (14 profiles sites and 1 reference site) at nitrate concentrations as great as 26.2 milligrams per liter as nitrogen $(n=749$; mean/median was 5.1/4.1 milligrams per liter as nitrogen). At all sites, wastewater effects were indicated by increased nitrate, boron, and specific conductance, and decreased $\mathrm{pH}$ and dissolved oxygen. The highest concentrations of nitrate typically occur in the deepest one-half of the freshwater zone and in intervals of both suboxic and oxic groundwater.

Metrics to evaluate changes in nitrogen in the vertical profiles over time include thickness-weighted mean and maximum nitrate concentrations and calculation of the nitrate mass per unit area at the 14 profile sites. The calculated nitrate mass ranged from 1,830 to 36,800 milligrams per square meter. Nitrate mass flux, determined for flux across a 500-meter-long section upgradient from Little Pond, ranged 
from 124.3 to 192.6 kilograms per year for the four full sampling rounds under three groundwater flow conditions (minimum, maximum, and mean water levels). The nitrate flux across the section, which is only 15 percent of the total pond shoreline length, represents a small part of the total nitrate flux to Little Pond.

Nitrate concentrations and physiochemical field measurements made before connections to the sewer system began (June 2016 and April 2017) and as connections were being made (April 2018) varied moderately by site between sampling rounds. A clear indication of decreases in mean and maximum nitrate concentrations at site F760 beginning early in the sewer-connection period (spring 2017) was evident from the frequent temporal sampling; mean and maximum concentrations at the site decreased steadily by 69.5 and 51.6 percent, respectively, between June 2017 and September 2019. Over the same period, however, mean and maximum nitrate concentrations at site F767 showed significant increases, demonstrating that the timing of water-quality changes at any one site depends on the date of conversion from septic systems to sewers at sites upgradient from the sampled location, proximity to the septic systems, and locations of upgradient systems along flow paths to the sampled site.

Sampling at the end of the transition period in June 2019 indicated decreases in mean profile concentrations (mean was -1.69 milligrams per liter as nitrogen) at 9 of the 14 sites. A statistical analysis using the Regional Kendall test for sampling points (MLS ports) grouped in specific relative depth ranges confirmed that statistically significant changes are occurring in at least one relative depth (0.4) group (nitrate: -0.76 milligram per liter per year; specific conductance: -12.1 microsiemens per centimeter per year; dissolved oxygen: 0.82 milligram per liter per year). Groundwater quality in the freshwater zone is expected to improve over time as indicated by decreases in specific conductance and concentrations of dissolved nitrogen species, boron, chloride, and fluoride, and increases in $\mathrm{pH}$ and dissolved-oxygen concentrations. The rate at which the water-quality improvements will result in decreases in nitrate mass loads to the coastal ponds depends primarily on groundwater traveltimes and the rate of flushing of wastewater constituents from the aquifer.

\section{References Cited}

American Society for Testing and Materials, 1985, Classification of soils for engineering purposes: American Society for Testing and Materials Annual Book of ASTM Standards D $2487-83$, v. 04.08 , p. 395-408.

Barlow, P.M., 2003, Ground water in freshwater-saltwater environments of the Atlantic coast: U.S. Geological Survey Circular 1262, 113 p. [Also available at https://doi.org/ 10.3133/cir1262.]
Cape Cod Commission [CCC], 2015, 208 plan-Cape Cod area wide water quality management plan update: Barnstable, Mass., Cape Cod Commission, [variously paged], accessed July 2021 at https://www.capecodcommi ssion.org/resource-library/file/?url=/dept/commission/team/ 208/208\%20Final/Cape_Cod_Area_Wide_Water_Quality_ Management_Plan_Update_June_15_2015.pdf.

Cape Cod Commission [CCC], 2017, Little Pond watershed implementation report, accessed July 2021 at http s://www.capecodcommission.org/resource-library/file/ ?url=/dept/commission/team/Website_Resources/208/ watershedreports/2017_Watershed_Report_UC_Little Pond.pdf.

Cape Cod Commission [CCC], 2018, Open data website: Waste water flow (watershed MVP) shapefile: Cape Cod Commission digital data, accessed November 14, 2018, at https://gis-cccommission.opendata.arcgis.com/.

Colman, J.A., LeBlanc, D.R., Böhlke, J.K., McCobb, T.D., Kroeger, K.D., Belaval, M., Cambareri, T.C., Pirolli, G.F., Brooks, T.W., Garren, M.E., Stover, T.B., and Keeley, A., 2018, Geochemical conditions and nitrogen transport in nearshore groundwater and the subterranean estuary at a Cape Cod embayment, East Falmouth, Massachusetts, 2013-14: U.S. Geological Survey Scientific Investigations Report 2018-5095, 69 p. [Also available at https://doi.org/ $10.3133 / \operatorname{sir} 20185095$.

Cunningham, W.L., and Schalk, C.W., comps., 2011, Groundwater technical procedures of the U.S. Geological Survey: U.S. Geological Survey Techniques and Methods, book 1, chap. A1, 151 p. [Also available at https://doi. org/10.3133/tm1a1.]

DeSimone, L.A., and Howes, B.L., 1996, Denitrification and nitrogen transport in a coastal aquifer receiving wastewater discharge: Environmental Science \& Technology, v. 30, no. 4, p. 1152-1162. [Also available at https://doi.org/ 10.1021/es950366p.]

Devlin, J.F., 2015, HydrogeoSieveXL—An Excel-based tool to estimate hydraulic conductivity from grain-size analysis: Hydrogeology Journal, v. 23, no. 4, p. 837-844. [Also available at https://doi.org/10.1007/s10040-015-1255-0.]

Emery, K.O., 1969, A coastal pond studied by oceanographic methods: New York, American Elsevier, 80 p.

Fairchild, G.M., Lane, J.W., Jr., Voytek, E.B., and LeBlanc, D.R., 2013, Bedrock topography of western Cape Cod, Massachusetts, based on bedrock altitudes from geologic borings and analysis of ambient seismic noise by the horizontal-to-vertical spectral-ratio method: U.S. Geological Survey Scientific Investigations Map 3233, 1 sheet, maps variously scaled, 17-p. pamphlet, on one CD-ROM. [Also available at https://doi.org/10.3133/sim3233.] 
Fetter, C.W., 1994, Applied hydrogeology: Columbus, Ohio, Merrill Publishing Company, 592 p.

Garabedian, S.P., LeBlanc, D.R., Gelhar, L.W., and Celia, M.A., 1991, Large-scale natural-gradient tracer test in sand and gravel, Cape Cod, Massachusetts-2. Analysis of spatial moments for a nonreactive tracer: Water Resources Research, v. 27, no. 5, p. 911-924. [Also available at https://doi.org/10.1029/91WR00242.]

Helsel, D.R., and Frans, L.M., 2006, The Regional Kendall test for trend: Environmental Science \& Technology, v. 40, no. 13, p. 4066-4073. [Also available at https://doi.org/ 10.1021/es051650b.]

Hem, J.D., 1985, Study and interpretation of the chemical characteristics of natural water: U.S. Geological Survey Water-Supply Paper 2254, 263 p. [Also available at https://doi.org/10.3133/wsp2254.]

Howarth, R.W., Walker, D., and Sharpley, A., 2002, Sources of nitrogen pollution to coastal waters of the United States-Implications for achieving coastal water quality goals: Estuaries, v. 25, p. 656-676. [Also available at https://doi.org/10.1007/BF02804898.]

Howes, B.L., Ramsey, J.S., Kelley, S.W., Samimy, R.I., Schlezinger, D.R., and Eichner, E.M., 2005, Linked watershed-embayment model to determine critical nitrogen loading thresholds for Great/Perch Pond, Green Pond, and Bournes Pond, Falmouth, Massachusetts: Boston, Mass., Massachusetts Department of Environmental Protection, Massachusetts Estuaries Project, 142 p., accessed November 13, 2018, at https://www.mass.gov/doc/greatperch-pond-green-pond-bournes-pond-falmouth-ma-2005.

Howes, B.L., Ramsey, J.S., Eichner, E.M., Samimy, R.I., Kelley, S.W., and Schlezinger, D.R., 2006, Linked watershed-embayment model to determine critical nitrogen loading thresholds for the Little Pond System, Falmouth, Massachusetts: Boston, Mass., Massachusetts Department of Environmental Protection, Massachusetts Estuaries Project, 221 p., accessed November 13, 2018, at https://www.mass.gov/files/documents/2016/08/mp/meplittlepond-uc.pdf.

LeBlanc, D.R., 1984, Sewage plume in a sand and gravel aquifer, Cape Cod, Massachusetts: U.S. Geological Survey Water-Supply Paper 2218, 28 p. [Also available at https://doi.org/10.3133/wsp2218.]

LeBlanc, D.R., Guswa, J.H., Frimpter, M.H., and Londquist, C.J., 1986, Ground-water resources of Cape Cod, Massachusetts: U.S. Geological Survey Hydrologic Investigations Atlas HA-692, 4 sheets., scale 1:24,000. [Also available at https://doi.org/10.3133/ha692.]
Massachusetts Department of Environmental Protection, 2008, Final Little Pond embayment system total maximum daily loads for total nitrogen: Boston, Mass., Massachusetts Department of Environmental Protection, 26 p., accessed November 13, 2018, at https://www.mass.gov/files/ documents/2016/08/xe/little.pdf.

Masterson, J.P., Stone, B.D., Walter, D.A., and Savoie, J.G., 1997, Hydrogeologic framework of western Cape Cod, Massachusetts: U.S. Geological Survey Hydrologic Atlas HA-741, 1 sheet, scale 1:25,000. [Also available at https://doi.org/10.3133/ha741.]

McCobb, T.D., LeBlanc, D.R., Barbaro, J.R., and Belaval, M., 2019, Baseline groundwater-quality data from a densely developed coastal neighborhood, Falmouth, Massachusetts (2016-2020) (ver. 3.0, April 2021): U.S. Geological Survey data release, accessed December 2021 at https://doi.org/ 10.5066/P9GEMMN6.

Millham, N.P., and Howes, B.L., 1994, Freshwater flow into a coastal embayment-Groundwater and surface water inputs: Limnology and Oceanography, v. 39, no. 8, p. 1928-1944. [Also available at https://doi.org/10.4319/ lo.1994.39.8.1928.]

Mullaney, J.R., 2015, Evaluation of the effects of sewering on nitrogen loads to the Niantic River, southeastern Connecticut, 2005-11: U.S. Geological Survey Scientific Investigations Report 2015-5011, 30 p. [Also available at https://doi.org/10.3133/sir20155011.]

National Oceanic and Atmospheric Administration, 2019, 8447930 Woods Hole, MA - Observed water levels: National Oceanic and Atmospheric Administration Tides \& Currents database, accessed July 23, 2019, at https://tidesa ndcurrents.noaa.gov/waterlevels.html?id=8447930.

Nixon, S.W., 1995, Coastal marine eutrophication-A definition, social causes, and future concerns: Ophelia, v. 41, no. 1, p. 199-219. [Also available at https://doi.org/10.1080/ 00785236.1995.10422044.]

Oldale, R.N., 1992, Cape Cod and the Islands-The geologic story: East Orleans, Mass., Parnassus Imprints, 205 p.

Repert, D.A., Barber, L.B., Hess, K.M., Keefe, S.H., Kent, D.B., LeBlanc, D.R., and Smith, R.L., 2006, Long-term natural attenuation of carbon and nitrogen within a groundwater plume after removal of the treated wastewater source: Environmental Science \& Technology, v. 40, no. 4, p. 1154-1162. [Also available at https://doi.org/10.1021/ es051442j.]

Robertson, W.D., Cherry, J.A., and Sudicky, E.A., 1991, Ground-water contamination from two small septic systems on sand aquifers: Ground Water, v. 29, no. 1, p. 82-92. [Also available at https://doi.org/10.1111/j.17456584.1991.tb00500.x.] 
Savoie, J.G., LeBlanc, D.R., Fairchild, G.M., Smith, R.L., Kent, D.B., Barber, L.B., Repert, D.A., Hart, C.P., Keefe, S.H., and Parsons, L.A., 2012, Groundwater-quality data for a treated-wastewater plume near the Massachusetts Military Reservation, Ashumet Valley, Cape Cod, Massachusetts, 2006-08: U.S. Geological Survey Data Series 648, CD-ROM, 11 p. [Also available at https://doi.org/ 10.3133/ds648.]

Sen, P.K., 1968, Estimates of the regression coefficient based on Kendall's tau: Journal of the American Statistical Association, v. 63, no. 324, p. 1379-1389. [Also available at https://doi.org/10.1080/01621459.1968.10480934.]

Short, F.T., and Burdick, D.M., 1996, Quantifying eelgrass habitat loss in relation to housing development and nitrogen loading in Waquoit Bay, Massachusetts: Estuaries, v. 19 , no. 3, p. 730-739. [Also available at https://doi.org/ 10.2307/1352532.]

Town of Falmouth, 2019a, Annual drinking water quality report: Town of Falmouth web page, accessed December 8, 2020, at https://www.falmouthma.gov/DocumentCenter/ View/7895/Consumer-Confidence-Report-2019.

Town of Falmouth, 2019b, Little Pond sewer service area project: Town of Falmouth web page, accessed April 22, 2018, at https://www.falmouthma.gov/228/Little-Pond-SewerService-Area-LPSSA-Pro/.

Uchupi, E., Giese, G.S., Aubrey, D.G., and Kim, D.-J., 1996, The late Quaternary construction of Cape Cod, Massachusetts-A reconsideration of the W.M. Davis Model: Geological Society of America Special Paper 309, 69 p. [Also available at https://doi.org/10.1130/08137-2309-4.]

U.S. Geological Survey, 2021, Site number-414124070311401 - MA-SDW 527-0055 (90MW0063): U.S. Geological Survey Groundwater Watch database, accessed March 8, 2021, at https://groundwaterwatch.usgs.gov/AWLSites.asp?mt= $\mathrm{g} \& \mathrm{~S}=414124070311401 \&$ ncd $=$ awl .

U.S. Geological Survey, 2019, USGS water data for the Nation: U.S. Geological Survey National Water Information System database, accessed July 23, 2019, at https://doi.org/ 10.5066/F7P55KJN.
U.S. Geological Survey [USGS], [variously dated], National field manual for the collection of water-quality data: U.S. Geological Survey Techniques of Water-Resources Investigations, book 9, chaps. A1-A10, accessed July 2019 at https://pubs.water.usgs.gov/twri9A.

Valiela, I., Foreman, K., LaMontagne, M., Hersh, D., Costa, J., Peckol, P., DeMeo-Andreson, B., D’Avanzo, C., Babione, M., Sham, C.H., Brawley, J., and Lajtha, K., 1992, Couplings of watersheds and coastal waters-Sources and consequences of nutrient enrichment in Waquoit Bay, Massachusetts: Estuaries, v. 15, no. 4, p. 443-457. [Also available at https://doi.org/10.2307/1352389.]

Valiela, I., Tomasky, G., Hauxwell, J., Cole, M., Cebrian, J., and Kroeger, K., 2000, Operationalizing sustainabilityManagement and risk assessment of land-derived nitrogen loads to estuaries: Ecological Applications, v. 10, no. 4, p. 1006-1023. [Also available at https://doi.org/10.1890/ 1051-0761(2000)010[1006:OSMARA]2.0.CO;2.]

Vanek, V., 1993, Groundwater regime of a tidally influenced coastal pond: Journal of Hydrology, v. 151, no. 2-4, p. 317-342. [Also available at https://doi.org/10.1016/00221694(93)90241-Z.]

Walter, D.A., and Whealan, A.T., 2005, Simulated water sources and effects of pumping on surface and ground water, Sagamore and Monomoy flow lenses, Cape Cod, Massachusetts: U.S. Geological Survey Scientific Investigations Report 2004-5181, 85 p. [Also available at https://doi.org/10.3133/sir20045181.]

Walter, D.A., McCobb, T.D., and Fienen, M.N., 2019, Use of a numerical model to simulate the hydrologic system and transport of contaminants near Joint Base Cape Cod, western Cape Cod, Massachusetts: U.S. Geological Survey Scientific Investigations Report 2018-5139, 98 p. [Also available at https://doi.org/10.3133/sir20185139.]

Weiskel, P.K., and Howes, B.L., 1992, Differential transport of sewage-derived nitrogen and phosphorus through a coastal watershed: Environmental Science \& Technology, v. 26, no. 2, p. 352-360. [Also available at https://doi.org/ 10.1021/es00026a017.] 


\section{Appendix 1. Methods of Data Collection, Laboratory Analysis, and Trend Evaluation}

\section{Monitoring Network Design and Installation}

The groundwater monitoring network is laid out in a grid pattern near the center of the Maravista peninsula (figs. 1 and 2 in the main report). The Maravista peninsula was selected because housing density is high, the fresh groundwater flow system is shallow and has short flow paths to discharge areas, and sewer connections were scheduled for 2017 in this area of the Little Pond Sewering Project, allowing for a year of monitoring before connections to the sewers began. The network covers a 12-block area of closely spaced properties. A grid pattern in a relatively small area was selected as the network design because it was expected to (1) provide a representative dataset of baseline groundwater quality before the transition from septic systems to sewers began, (2) allow changes in groundwater quality in response to sewering to be observed over time, and (3) support quantitative analysis of hydrologic and water-quality results, such as groundwater flow directions, rates, traveltimes, and changes in nitrogen concentrations and loading to the adjacent ponds.

The network consists of 14 profile sites that each include a multilevel sampler (MLS) for groundwater-quality data collection and a shallow (screened near the water table) monitoring well for groundwater-level measurements (fig. 2 in the main report). Four sites along a transverse transect across the center of the network (F760, F764, F765, and F766) also include a deep monitoring well for groundwater-level measurements in the deeper part of the fresh groundwater zone. Two temporary tide-stage gages were installed and operated from February 18, 2016, to March 25, 2016, in Little and Great Ponds to determine local tidal ranges and the effects of tides on groundwater levels in the study area. An existing MLS (F724-M01), which is about 4 kilometers east of the study area in a residential coastal setting (next to Eel Pond [fig. 1]) that is similar to the Maravista peninsula but not undergoing sewering also was sampled periodically as a reference site. "F" in the site name is shorthand for "MA-FSW," and "M01" in the site name indicates a 15-port MLS.

Wells and MLS were installed with a direct-push drilling machine (Geoprobe model 7822DT, Salinas, Kansas). Before well installation, continuous sediment cores were collected at four sites (F760, F764, F766, and F772) to determine subsurface lithologic conditions and the approximate depth to the freshwater/saltwater boundary.

Four sediment samples representative of subsurface conditions in the study area (ranging from coarse sand with gravel to medium sand with silt) were subsampled from the cores and submitted for grain-size analysis (fig. 4; table 2). Grain-size distributions of the gravel and sand fractions of each sample were determined by dry sieving at the U.S. Geological Survey (USGS) Sediment Laboratory in Louisville, Kentucky. The hydraulic conductivity of grain-size samples was estimated by using as many as 13 of the 15 empirical and semi-empirically derived equations included in the HydrogeoSieveXL software (Devlin, 2015); the equations that were used for each sample met the grain-size-distribution criteria documented in the software. For equations that use temperature-dependent fluid parameters such as viscosity and density, a temperature of 10 degrees Celsius, which is characteristic of groundwater on Cape Cod, was used.

To determine the location of the freshwater/saltwater boundary at the four coring sites, porewater salinity was measured during drilling by mixing deionized water with about 100 cubic centimeters of sediment from each coring interval. A specific conductance meter was used to determine the relative salt content of the resulting slurry. The depth to the boundary and altitude of the water table at the four locations were used to estimate the depth to the boundary at the other 10 locations in the network to guide the design and installation of the MLS. The actual position of the boundary at each location was ultimately determined by measuring the specific conductance of water samples collected from the MLS.

The measurements and estimates of the depth to the water table and thickness of the fresh groundwater lens were used to select the depths of the monitoring well screens and MLS sampling ports. MLS were designed to minimize the number of ports set in saltwater. Each MLS consists of 15 color-coded sampling tubes connected to screened sampling ports that are variably spaced from near the water table to just below the freshwater/saltwater boundary. Vertical spacing of the ports varies from 0.31 meter $(\mathrm{m})$ near the water table to $1.2 \mathrm{~m}$ near the freshwater/saltwater boundary. The $0.64-$ centimeter $(\mathrm{cm})$ outer-diameter polyethylene color-coded tubes run inside a 3.175-cm-diameter polyvinyl chloride (PVC) pipe from land surface to the port depth, where they exit the PVC casing and are screened with a nylon mesh. The monitoring wells are constructed of 5.1-cm PVC casing and fitted with screens $0.49 \mathrm{~m}$ long. Temporary tide gages were constructed of a short section of 5.1-cm-diameter PVC casing and well screen attached to a hand-driven anchor stake. The measuring-point altitudes for the MLS, wells, and tide gages were determined by using differential leveling to relate groundwater and tide levels and water-quality observations to a common vertical datum. The procedures for differential leveling are documented in Kenney (2010). Horizontal coordinates were determined by the Global Positioning System (GPS) following the procedures documented by Rydlund and Densmore (2012). Vertical coordinates are referenced to the National Geodetic Vertical Datum 
of 1929 (NGVD 29). Horizontal coordinates are referenced to the North American Datum of 1983 (NAD 83). The construction data (for example, port spacing and depths) and altitudes and location coordinates are available in the project data release (McCobb and others, 2019).

\section{Water-Level Measurements}

Groundwater levels were measured in monitoring wells to determine groundwater flow rates and directions and the extent of tidal influence on groundwater levels. Surface-water levels in Great and Little Ponds were measured to determine tidal amplitudes and assess the effects of tides on the fresh groundwater system below the peninsula.

\section{Groundwater Levels}

Groundwater levels were measured during each sampling event in the monitoring wells that were paired with the MLS. Measurements were made with a calibrated electronic water-level tape. The groundwater-level snapshots collected during the four full sampling events were used to evaluate the temporal variability in groundwater-level altitudes and rates and directions of groundwater flow (that is, the configuration of the water table) (USGS, 2020a). Repeated measurements of groundwater levels during individual sampling events indicated that water levels in wells nearest to the tidal ponds are likely affected by the tides. Therefore, continuous water levels (15-minute interval) were evaluated using data recorders (Hobo Water Level Logger model U20-001-04, Onset Computer, Bourne, Massachusetts) at all 14 shallow wells for a 37-day period from June 27 to August 2, 2016. Water levels were corrected for barometric pressure by using data from a recorder that was stationed in ambient air in the study area. The water-level and barometric-pressure data are available in the USGS National Water Information System database
(USGS, 2020a), at https://doi.org/10.5066/F7P55KJN. The continuous data showed that groundwater levels were affected by daily and bimonthly tidal cycles (fluctuations in the range of 10-18 cm); the magnitude of the effect decreased with distance from shore. Because of the tidal fluctuations, water-level altitudes and hydraulic gradients were evaluated by examining (1) instantaneous measurements at the 14 sites in the network at selected times (maximum [July 11, 2016 00:00], and minimum [July 19, 2016 22:00]) water levels from the 15-minute data, as observed at site F760 near the center of the peninsula), and (2) the mean of daily mean water levels for each site for the 37-day period. The water-table configurations for the maximum, minimum, and average daily conditions were used to characterize gradients and flow directions (table 1.1). The three conditions also were used to determine horizontal hydraulic gradients for use in nitrate flux calculations. Water-level data were quality assured and approved for publication according to USGS data-management procedures (USGS, 2020b).

\section{Great Pond and Little Pond Levels}

Temporary tide gages were installed in Little Pond and Great Pond (fig. 2 in the main report) to determine the magnitude of tidal fluctuations and mean tidal altitudes in these ponds. Data were collected at 15-minute intervals with Hobo water-level dataloggers (model U20-001-04, Onset Computer, Bourne, Massachusetts). Tide levels were corrected for barometric pressure by using a data recorder that was stationed in ambient air in the study area using a density value of water for saltwater (1,025.005 kilograms per cubic meter). The gages were operated for about 5 weeks, from February 18 to March 25, 2016 (fig. 5C). Initial and final water levels were measured manually relative to NGVD 29 to provide known altitude reference points at the beginning and ending points of the continuous record. The tide data are available in the USGS National Water Information System database (USGS, 2020a) at https://doi.org/10.5066/F7P55KJN.

Table 1.1. Water-level altitudes at selected times of maximum, minimum, and mean levels at site F760 near the center of the Maravista peninsula, Falmouth, Massachusetts, June 27 to August 2, 2016.

[Locations of sites are shown on figure 2. F is shorthand for MA-FSW. Dates are given in month/day/year. Times are given in hour:minute (military)]

\begin{tabular}{|c|c|c|c|c|c|c|c|c|c|c|c|c|c|c|c|}
\hline \multirow{2}{*}{ Statistic } & \multirow{2}{*}{$\begin{array}{l}\text { Date and } \\
\text { time }\end{array}$} & \multicolumn{14}{|c|}{ Water-level altitude, in meters } \\
\hline & & F757 & F761 & F762a & F763 & F764 & F760 & F765 & F766 & F770 & F767 & F768 & F769 & F771 & F772 \\
\hline $\begin{array}{l}\text { Maximum } \\
(\text { F760) }\end{array}$ & $\begin{array}{c}7 / 11 / 2016 \\
00: 00\end{array}$ & 0.451 & 0.538 & 0.565 & 0.347 & 0.418 & 0.517 & 0.508 & 0.300 & 0.411 & 0.448 & 0.492 & 0.425 & 0.458 & 0.456 \\
\hline $\begin{array}{l}\text { Minimum } \\
\quad(\text { F760) }\end{array}$ & $\begin{array}{c}7 / 19 / 2016 \\
22: 00\end{array}$ & 0.298 & 0.376 & 0.353 & 0.329 & 0.253 & 0.335 & 0.338 & 0.319 & 0.243 & 0.270 & 0.309 & 0.296 & 0.275 & 0.280 \\
\hline $\begin{array}{l}\text { Mean daily } \\
\text { mean by } \\
\text { site }\end{array}$ & $\begin{array}{r}6 / 27 / 2016 \\
8 / 2 / 2016\end{array}$ & 0.392 & 0.461 & 0.433 & 0.351 & 0.359 & 0.427 & 0.424 & 0.322 & 0.351 & 0.373 & 0.402 & 0.365 & 0.379 & 0.369 \\
\hline
\end{tabular}

aWater levels for site F762 are estimated based on surrounding wells and manual measurements. 


\section{Water-Quality Sampling and Analysis}

Groundwater samples for water-quality analyses were collected during four full and several partial sampling events between June 2016 and June 2019, which encompass the presewering and transitional sewering periods (table 1 in the main report). During the full events, the entire monitoring network was sampled. During the partial events, samples were collected from two locations (F760 and F767) to evaluate temporal variability and possible improvements in groundwater quality during the transitional period. The initial full sampling round was also used to locate the freshwater/saltwater boundary and determine the thickness of the freshwater zone; subsequent sampling rounds focused on the freshwater zone only. Freshwater thickness was determined by using specific conductance and chloride concentrations in samples collected from the entire network of MLS ports $(n=209)$. A specific conductance less than 3,000 microsiemens per centimeter at 25 degrees Celsius was considered to represent fresh groundwater.

For the full sampling events, groundwater samples were collected from the 162 MLS ports at the 14 sites that are above the freshwater/saltwater boundary. For the partial sampling events, two vertical water-quality profiles (F760 and F767), consisting of 8 and 11 samples, respectively, were obtained by sampling the MLS ports in the fresh groundwater zone. Samples were collected by using methods documented in Savoie and others (2012) and the USGS National Field
Manual (USGS, 2018). Groundwater samples were collected with a peristaltic pump fitted with Norprene pump tubing (Masterflex food-grade tubing A60F, Vernon Hills, Illinois).

After the MLS tubing was purged, field water-quality properties were measured in unfiltered grab samples. Specific conductance was measured with a Thermo Orion Star (model A222) conductivity meter. The $\mathrm{pH}$ and temperature were measured with an Orion Star (model A221) pH meter, an Orion Ross Sure-Flow (model 8172BNWP) pH electrode, and an Orion (model 927007MD) stainless steel, temperaturecompensating probe. Dissolved-oxygen concentrations less than 1 milligram per liter were measured in the field by using a quantitative colorimetric method (CHEMetrics V-2000 photometer and $\mathrm{K}-7553$ Vacuvial self-filling reagent ampoules, CHEMetrics, 2018). Dissolved-oxygen concentrations greater than 1 milligram per liter were measured in samples collected in glass biochemical oxygen demand (BOD) bottles that were stoppered and chilled until measurement in the lab (within 6 hours of collection) with a benchtop dissolved oxygen probe and meter (YSI model 58).

All laboratory samples were analyzed by the USGS National Water-Quality Laboratory (NWQL). The measured water-quality constituents, sampling methods and reporting limits, and associated quality assurance/quality control $(\mathrm{QA} / \mathrm{QC})$ protocols are listed in table 1.2. Samples for $\mathrm{QA} / \mathrm{QC}$ were collected at a minimum rate of 10 percent of the total number of environmental samples for each constituent. Quality-control samples included equipment blanks and replicates.

Table 1.2. Field and laboratory methods, reporting limits, data-quality requirements, preservation requirements, and hold times for groundwater samples collected in the Maravista study area, Falmouth, Massachusetts.

[All samples analyzed by the U.S. Geological Survey (USGS) National Water-Quality Laboratory (NWQL), Denver, Colorado; RPD, relative percent difference; ---, not applicable; $\mu \mathrm{S} / \mathrm{cm}$, microsiemen per centimeter at 25 degrees Celsius; ATC, automatic temperature compensation; ${ }^{\circ} \mathrm{C}$, degree Celsius; mg $/ \mathrm{L}$, milligram per liter; >, greater than; as N, as nitrogen; $\mathrm{mL}$, milliliter; HDPE, high-density polyethylene; <, less than; $\mathrm{N}$, normal; $\mathrm{H}_{2} \mathrm{SO}_{4}$, sulfuric acid; $\mathrm{P}$, phosphorus; $\mu \mathrm{g} / \mathrm{L}$, microgram per liter]

\begin{tabular}{|c|c|c|c|c|c|c|c|c|}
\hline Parameter & $\begin{array}{l}\text { Labora- } \\
\text { tory/lab } \\
\text { code (LC) }\end{array}$ & Method/reference & $\begin{array}{l}\text { Reporting } \\
\text { limit }\end{array}$ & Unit & $\begin{array}{c}\text { Sample container/vol- } \\
\text { ume/preservative }\end{array}$ & Filtereda & $\begin{array}{l}\text { Maxi- } \\
\text { mum hold } \\
\text { time, in } \\
\text { days }\end{array}$ & $\begin{array}{c}\text { Lab } \\
\text { dupli- } \\
\text { cates } \\
\text { - RPD } \\
\text { accep- } \\
\text { tance, } \\
\text { in per- } \\
\text { cent }\end{array}$ \\
\hline $\mathrm{pH}$ & Field & $\begin{array}{l}\text { Glass, ion selective electrode, } \\
\text { with ATC probe and meter } \\
\text { (USGS, 2021) }\end{array}$ & --- & $\begin{array}{l}\text { Stan- } \\
\text { dard } \\
\text { units }\end{array}$ & Field grab & No & --- & -- \\
\hline
\end{tabular}


Table 1.2. Field and laboratory methods, reporting limits, data-quality requirements, preservation requirements, and hold times for groundwater samples collected in the Maravista study area, Falmouth, Massachusetts. —Continued

[All samples analyzed by the U.S. Geological Survey (USGS) National Water-Quality Laboratory (NWQL), Denver, Colorado; RPD, relative percent difference; ---, not applicable; $\mu \mathrm{S} / \mathrm{cm}$, microsiemen per centimeter at 25 degrees Celsius; ATC, automatic temperature compensation; ${ }^{\circ} \mathrm{C}$, degree Celsius; mg/L, milligram per liter; >, greater than; as $\mathrm{N}$, as nitrogen; $\mathrm{mL}$, milliliter; $\mathrm{HDPE}$, high-density polyethylene; <, less than; $\mathrm{N}$, normal; $\mathrm{H}_{2} \mathrm{SO}_{4}$, sulfuric acid; $\mathrm{P}$, phosphorus; $\mu \mathrm{g} / \mathrm{L}$, microgram per liter]

\begin{tabular}{|c|c|c|c|c|c|c|c|c|}
\hline Parameter & $\begin{array}{l}\text { Labora- } \\
\text { tory/lab } \\
\text { code (LC) }\end{array}$ & Method/reference & $\begin{array}{l}\text { Reporting } \\
\text { limit }\end{array}$ & Unit & $\begin{array}{l}\text { Sample container/vol- } \\
\text { ume/preservative }\end{array}$ & Filtereda & $\begin{array}{l}\text { Maxi- } \\
\text { mum hold } \\
\text { time, in } \\
\text { days }\end{array}$ & $\begin{array}{c}\text { Lab } \\
\text { dupli- } \\
\text { cates } \\
\text { - RPD } \\
\text { accep- } \\
\text { tance, } \\
\text { in per- } \\
\text { cent }\end{array}$ \\
\hline $\begin{array}{l}\text { Nitrite } \\
\qquad\left(\mathrm{NO}_{2}^{-}\right)\end{array}$ & $\begin{array}{l}\text { NWQL/ } \\
\quad \text { LC3117 }\end{array}$ & $\begin{array}{l}\text { Colorimetry, diazotization, } \\
\text { automated-segmented flow } \\
\text { (Fishman, 1993) }\end{array}$ & 0.001 & $\begin{array}{l}\mathrm{mg} / \mathrm{L} \\
\quad \text { as } \mathrm{N}\end{array}$ & $\begin{array}{l}\text { 125-mL HDPE bottle, } \\
\text { amber, chilled }\end{array}$ & Yes & 30 & $<10$ \\
\hline $\begin{array}{l}\text { Total ni- } \\
\text { trogen }\end{array}$ & $\begin{array}{l}\text { NWQL/ } \\
\text { LC2755 }\end{array}$ & $\begin{array}{l}\text { Alkaline persulfate digestion } \\
\quad(\text { Patton and Kryskalla, 2003) }\end{array}$ & 0.05 & $\begin{array}{l}\mathrm{mg} / \mathrm{L} \\
\quad \text { as } \mathrm{N}\end{array}$ & $\begin{array}{l}\text { 125-mL HDPE bottle, } \\
\text { amber, acidified with } \\
1 \mathrm{~mL} 4.5 \mathrm{~N} \mathrm{H}_{2} \mathrm{SO}_{4} \\
\text { chilled }\end{array}$ & Yes & 30 & $<10$ \\
\hline $\begin{array}{l}\text { Total } \\
\text { phos- } \\
\text { phorus }\end{array}$ & $\begin{array}{l}\text { NWQL/ } \\
\text { LC2758 }\end{array}$ & $\begin{array}{l}\text { Alkaline persulfate digestion } \\
\quad(\text { Patton and Kryskalla, 2003) }\end{array}$ & 0.01 & $\begin{array}{l}\mathrm{mg} / \mathrm{L} \\
\text { as P }\end{array}$ & $\begin{array}{l}\text { 125-mL HDPE bottle, } \\
\text { amber, acidified with } \\
1 \mathrm{~mL} 4.5 \mathrm{~N} \mathrm{H}_{2} \mathrm{SO}_{4}, \\
\text { chilled }\end{array}$ & Yes & 30 & $<10$ \\
\hline $\begin{array}{l}\text { Chloride } \\
\qquad\left(\mathrm{Cl}^{-}\right)\end{array}$ & $\begin{array}{l}\text { NWQL/ } \\
\text { LC1571 }\end{array}$ & $\begin{array}{l}\text { Ion exchange chromatographic, } \\
\text { automated (Fishman and Fried- } \\
\text { man, 1989) }\end{array}$ & 0.02 & $\mathrm{mg} / \mathrm{L}$ & $\begin{array}{l}\text { 250-mL HDPE bottle, } \\
\text { clear }\end{array}$ & Yes & 180 & $<10$ \\
\hline $\begin{array}{l}\text { Fluoride } \\
\qquad\left(\mathrm{F}^{-}\right)\end{array}$ & $\begin{array}{l}\text { NWQL/ } \\
\text { LC651 }\end{array}$ & $\begin{array}{l}\text { Ion exchange chromatographic, } \\
\text { automated (Fishman and Fried- } \\
\text { man, 1989) }\end{array}$ & 0.01 & $\mathrm{mg} / \mathrm{L}$ & $\begin{array}{l}\text { 250-mL HDPE bottle, } \\
\text { clear }\end{array}$ & Yes & 180 & $<10$ \\
\hline $\begin{array}{l}\text { Magne- } \\
\quad \text { sium } \\
\left(\mathrm{Mg}^{+2}\right)\end{array}$ & $\begin{array}{l}\text { NWQL/ } \\
\text { LC663 }\end{array}$ & $\begin{array}{l}\text { Inductively coupled plasma- } \\
\text { atomic emission spectrometry } \\
\text { (Fishman, 1993) }\end{array}$ & 0.01 & $\mathrm{mg} / \mathrm{L}$ & $\begin{array}{l}\text { 250-mL acid rinsed, } \\
\text { HDPE bottle, clear, } \\
\text { acidified with } 2 \mathrm{~mL} \\
7.5 \mathrm{~N} \text { Ultrex } \mathrm{HNO}_{3}\end{array}$ & Yes & 180 & $<10$ \\
\hline $\begin{array}{l}\text { Sulfate } \\
\qquad\left(\mathrm{SO}_{4}^{-2}\right)\end{array}$ & $\begin{array}{l}\text { NWQL/ } \\
\text { LC1572 }\end{array}$ & $\begin{array}{l}\text { Ion exchange chromatographic, } \\
\text { automated (Fishman and Fried- } \\
\text { man, 1989) }\end{array}$ & 0.02 & $\mathrm{mg} / \mathrm{L}$ & $\begin{array}{l}\text { 250-mL HDPE bottle, } \\
\text { clear }\end{array}$ & Yes & 180 & $<10$ \\
\hline
\end{tabular}

${ }^{a}$ Samples were filtered with 0.45 -micrometer capsule filter. 


\section{Methods for Trend Evaluation Using Vertical Profiles}

Temporal and spatial variability and trends in field water-quality characteristics and nitrogen concentrations were evaluated by using detailed vertical profiles of water quality from 15 MLS, including the MLS at the reference location. Qualitative analysis was done by examining spatial differences and temporal changes in graphical water-quality profiles. Statistical analysis was done by comparing vertically integrated concentrations at profile locations. Graphical profiles of field water-quality characteristics and concentrations of nitrogen, chloride, and boron for each of the 15 locations are available in figure 1.1. The complete dataset is available in McCobb and others (2019).

\section{Maximum and Vertically Integrated Mean Nitrate Concentration}

Maximum and vertically integrated mean nitrate concentrations for each profile and sampling event were determined for sampling ports between the water table and the freshwater/ saltwater boundary. For the purposes of this analysis, this boundary was delineated as the interpolated vertical position of specific conductance equal to 3,000 microsiemens per centimeter at 25 degrees Celsius. The vertical interval between the water table and the freshwater/saltwater boundary is referred to herein as the freshwater zone.

Maximum nitrate concentrations were compiled for the freshwater zone at each of the 15 locations for the four full sampling rounds (June 2016, April 2017, April 2018, and June 2019). Vertically integrated mean concentrations were calculated for each of the 15 MLS sampled during the four full sampling rounds based on measured concentrations at sampling ports in the freshwater zone. Each measured concentration in each vertical profile was weighted by the aquifer thickness that it represented by calculating the product of the concentration and the representative thickness. The thickness was calculated as the sum of one-half the distances to the vertically adjacent sampling ports. For the topmost and lowermost ports, the vertical locations of the water table and freshwater/saltwater boundaries, respectively, were used. The sum of the thickness-weighted concentrations was divided by the total freshwater thickness to produce a mean profile concentration in units of milligrams per liter as nitrogen.

\section{Vertically Integrated Mass of Nitrate}

The vertically integrated nitrate mass per square meter of land area at each MLS location for each sampling event was calculated following methods described by Repert and others (2006). For each pair of vertically adjacent MLS ports, the product of the mean of the concentrations at the two ports and the vertical distance between the ports was calculated. For the uppermost and lowermost intervals, the concentrations at the uppermost or lowermost port, and distance to the water table or lowermost port and or freshwater/saltwater boundary, respectively, were used. The products were summed for all the intervals and multiplied by an effective porosity of 0.39 (Garabedian and others, 1991) to obtain the total dissolved mass in units of milligrams per unit area land surface (in this case per square meter).

\section{Nitrate Mass Flux Toward Little Pond}

Nitrate mass-flux (or loading) estimates through section $B-B^{\prime}$, a 500 -meter (m) cross section upgradient from Little Pond (fig. 2 in the main report), were calculated for each full sampling round by using the product of water flux estimated from Darcy's Law and nitrate concentrations. The estimates represent instantaneous mass loads at the time of sampling for minimum, maximum, and mean water-level conditions (see the "Groundwater Levels" section). Mass flux was calculated from interpolated concentrations, which were assumed to be constant in the volume of aquifer surrounding the sampling port. The method also assumed that the porosity is constant throughout the aquifer. For nitrate and conservative constituents (such as boron), adsorption is negligible, and dissolvedphase mass flux is equivalent to total mass flux. The estimation method follows similar approaches used in other studies to calculate mass flux (Weiskel and Howes, 1991; McCobb and others, 2003; Barbaro and others, 2019).

Section $B-B^{\prime}$ extends from just north of site F757, through sites F764 and F767, to just south of site F771 (fig. 2 in the main report). The section was selected because it is nearly perpendicular to groundwater flow towards Little Pond. The distances of the sites from the pond are similar, ranging between 70 and $90 \mathrm{~m}$, except for site F764, which is about $30 \mathrm{~m}$ from the pond. An example of the estimation approach from June 2016 is shown in figures $12 A-C$ in the main report.

A simplified flow field through the section based on Darcy's Law was established for a two-dimensional grid of cells spaced throughout the section (fig. $12 B$ in the main report). The section line was divided into four columns of cells, each with constant flow properties from top to bottom, and each containing one MLS. Each column extends half the distance from its MLS to the MLS on either side. The section line extends $50 \mathrm{~m}$ beyond the last MLS on each end. Each column has 18 cells in the vertical direction that are $0.5 \mathrm{~m}$ thick and $100-150 \mathrm{~m}$ wide. The top of the uppermost cells extends to the highest water table positions at the MLS locations for the measurement period. The two-dimensional grid extends downward to an altitude of $-8 \mathrm{~m}$ NGVD 29 , approximately the position of the freshwater/saltwater boundary at site F757. The groundwater-flow field is assumed to be constant from top to bottom and oriented perpendicular to the section but varies in magnitude laterally along the section as described below. 

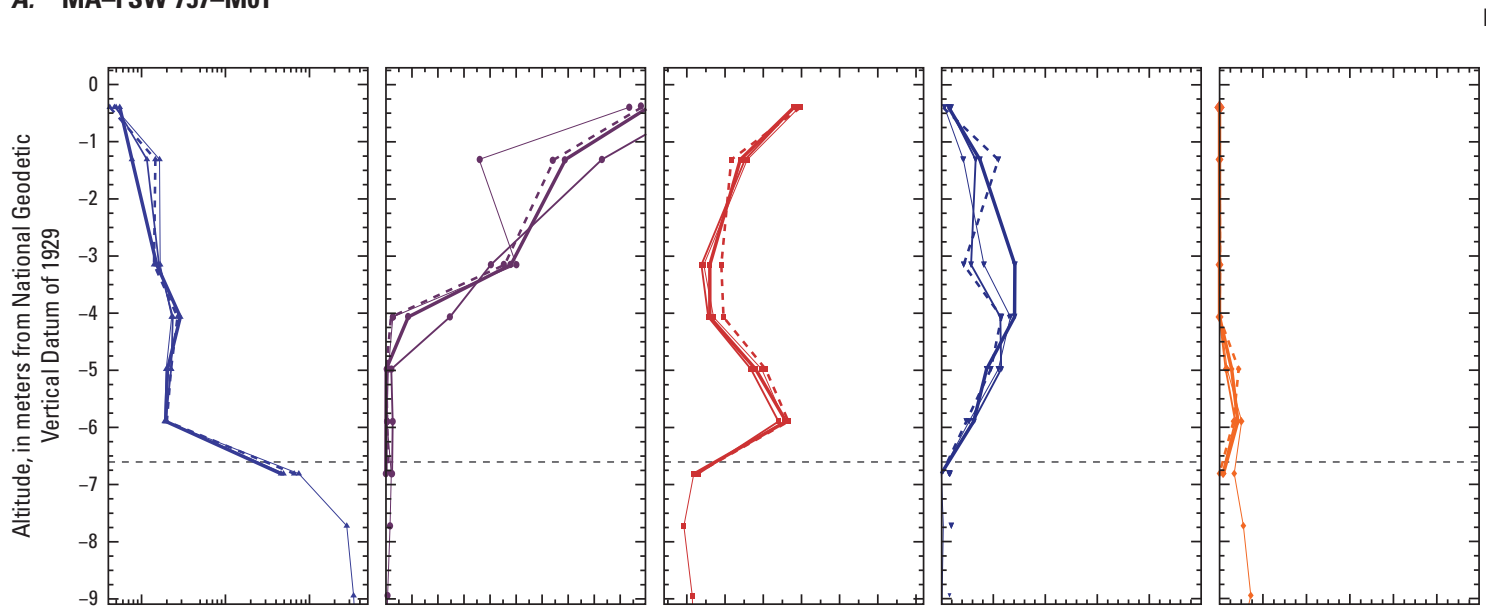

Boron, in micrograms per liter

B. MA-FSW 761-M01
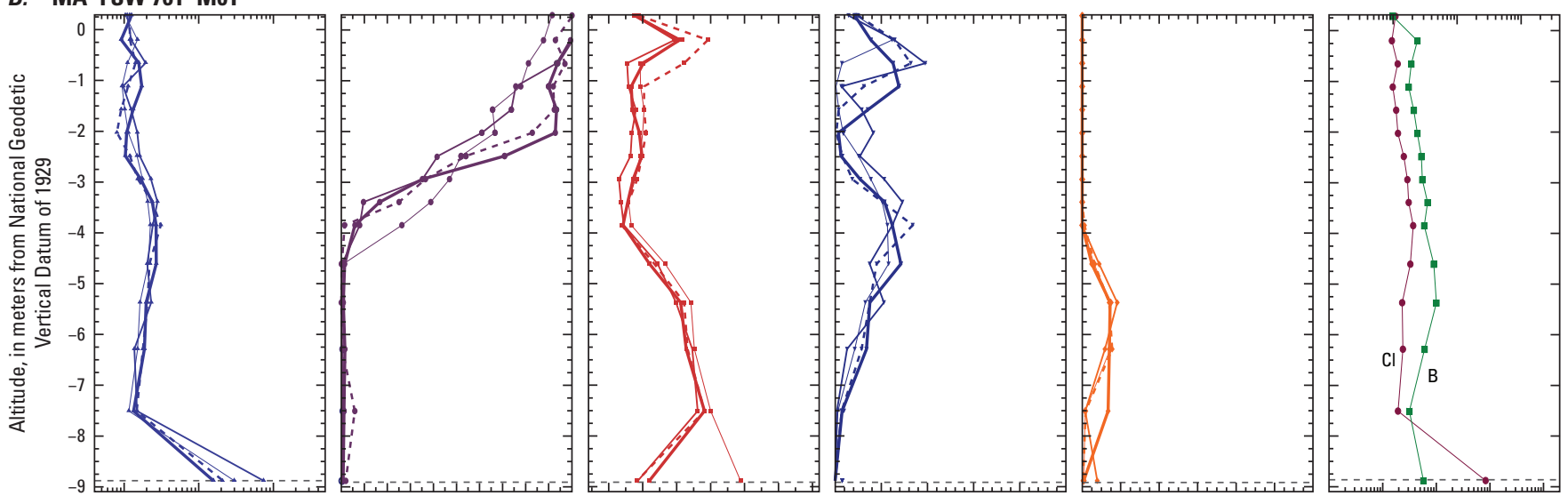

\section{MA-FSW 762-M01}
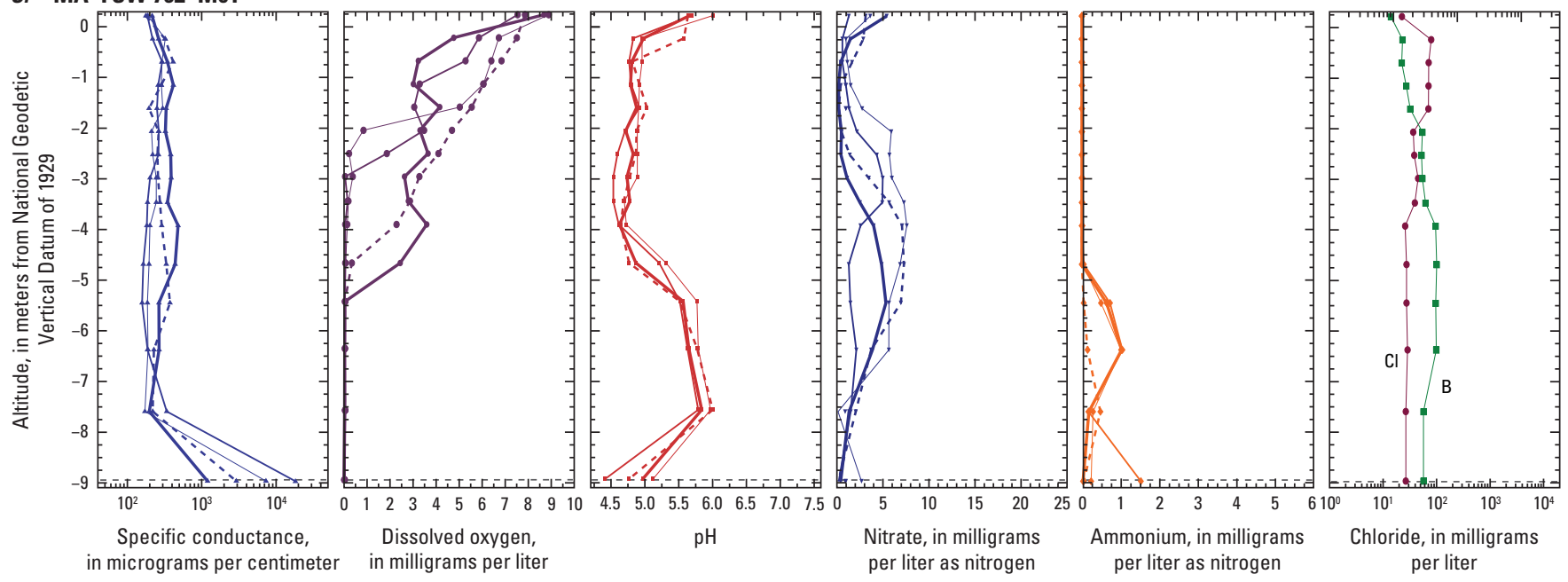

EXPLANATION

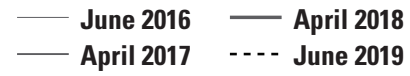

Estimated position of freshwater/saltwater boundary in June 2016—Measured as specific conductance greater than 3,000 micrograms per centimeter

Figure 1.1. Vertical profiles of specific conductance, dissolved oxygen, $\mathrm{pH}$, nitrate, ammonium, chloride, and boron at multilevel samplers along Maravista Peninsula, East Falmouth, Massachusetts. Each site (fig. 2) was sampled in June 2016, April 2017, April 2018, and June 2019. A, F757. B, F761. C, F762. D, F763. E, F764. F, F760. G, F765. H, F766. I, F770. J, F767. K, F768. L, F769. M, F771. N, F772. O, F724. 
D. MA-FSW 763-M01

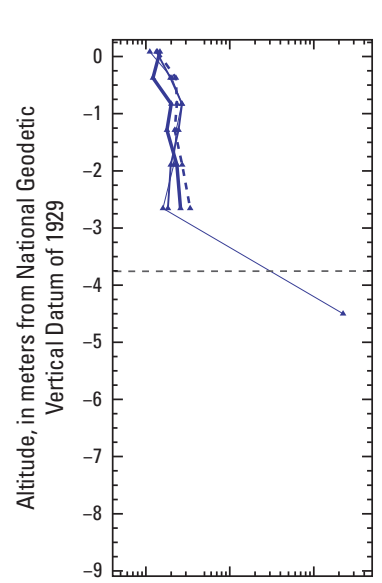

\section{E. MA-FSW 764-M01}

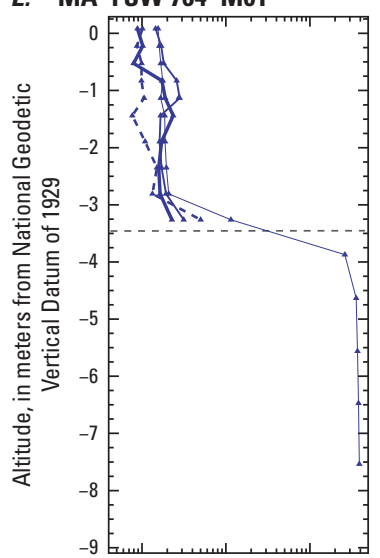

F. MA-FSW 760-M01

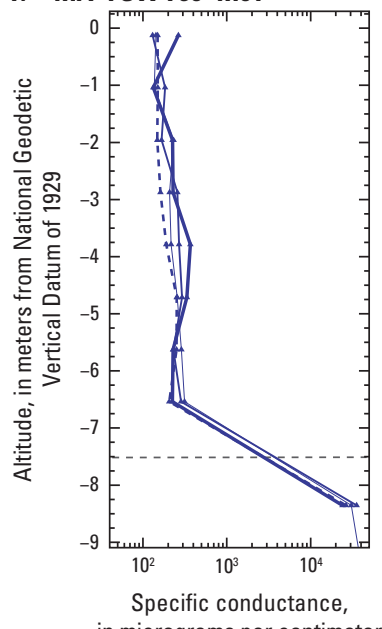

in micrograms per centimeter
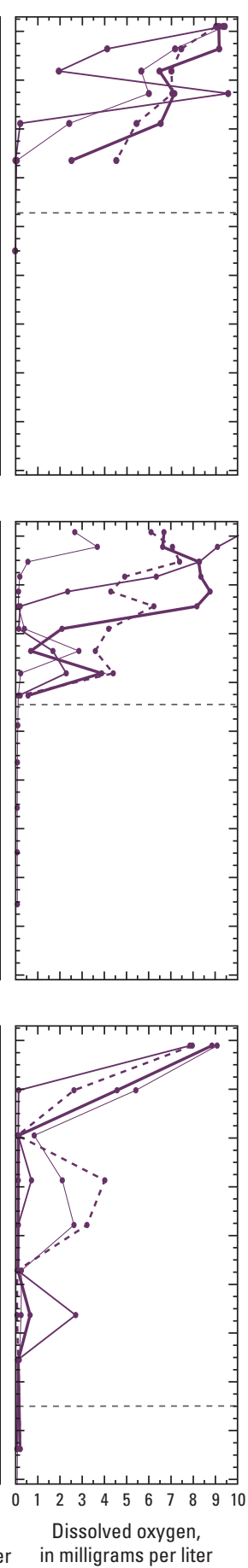

in milligrams per liter
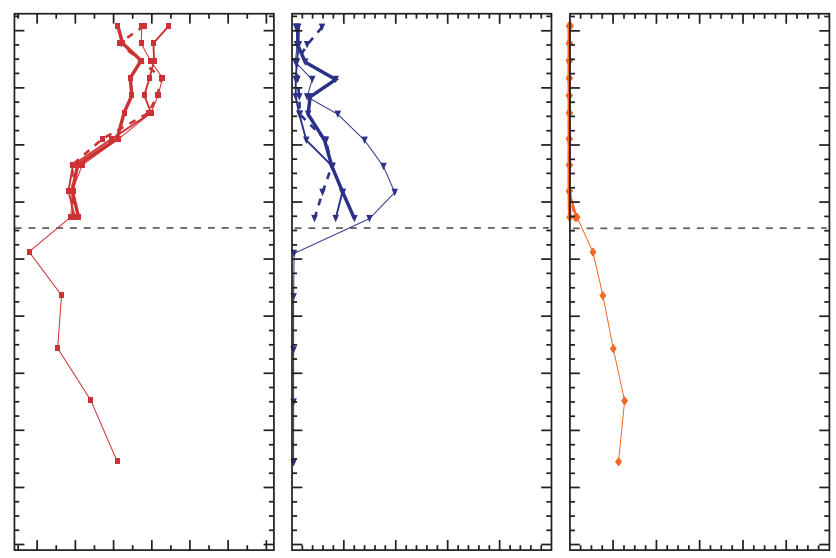

Boron, in micrograms per liter
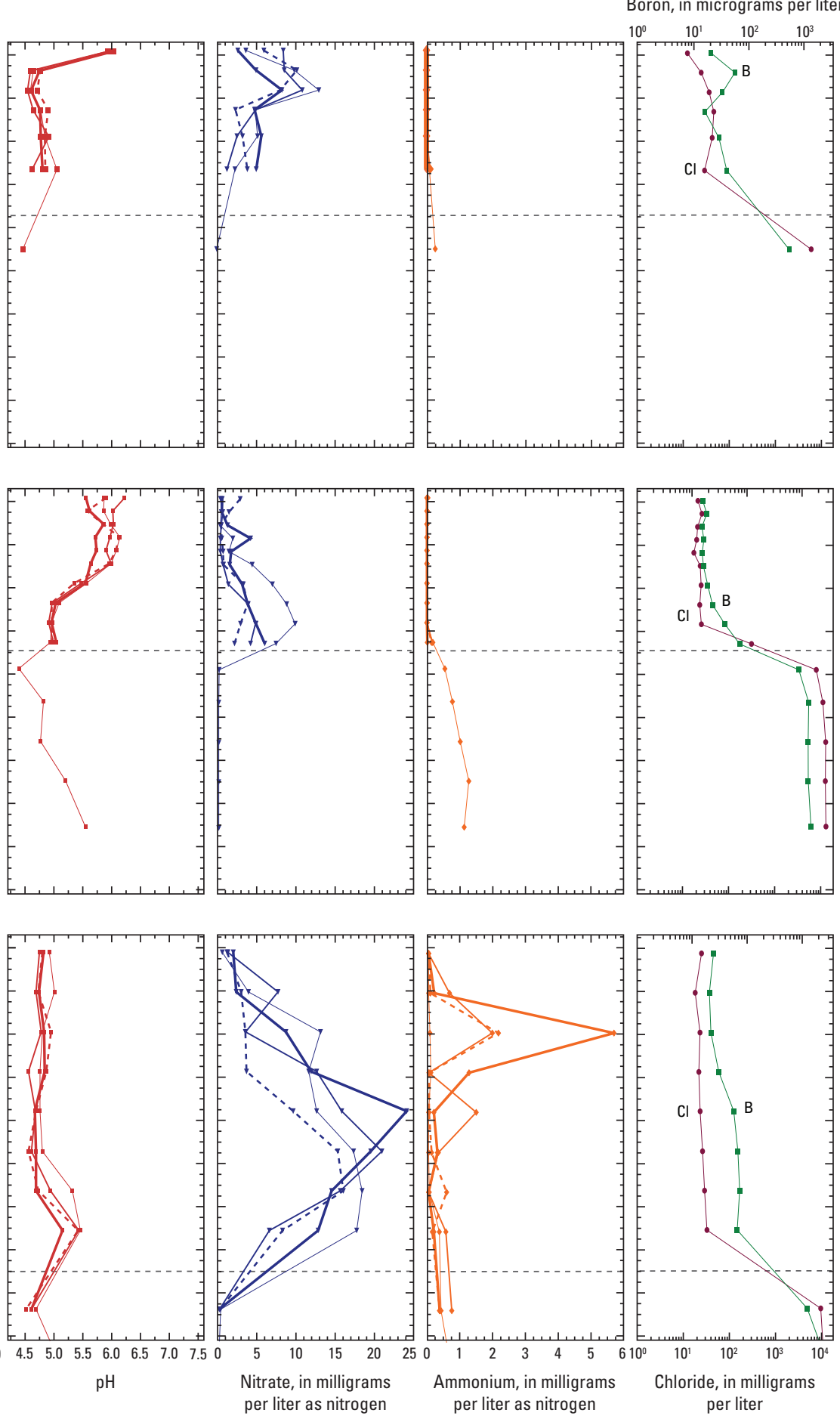

EXPLANATION

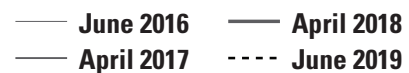

Estimated position of freshwater/saltwater boundary in June 2016-Measured as specific conductance greater than 3,000 micrograms per centimeter

Figure 1.1.-Continued 

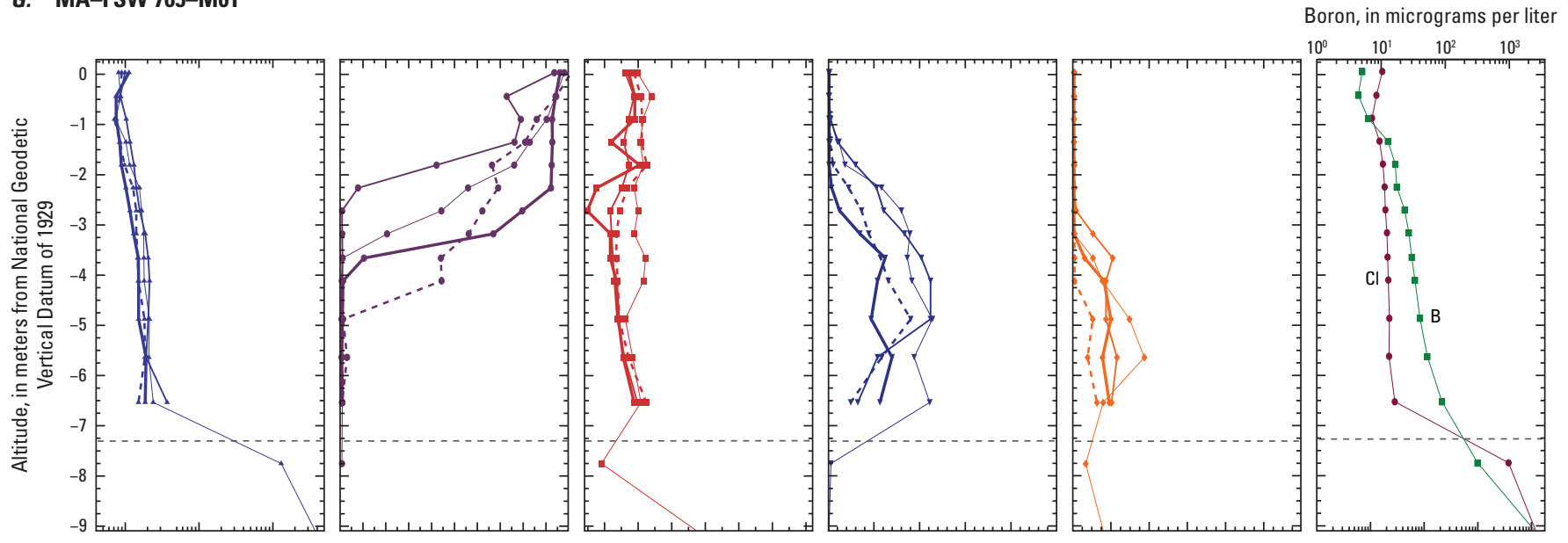

\section{H. MA-FSW 766-M01}
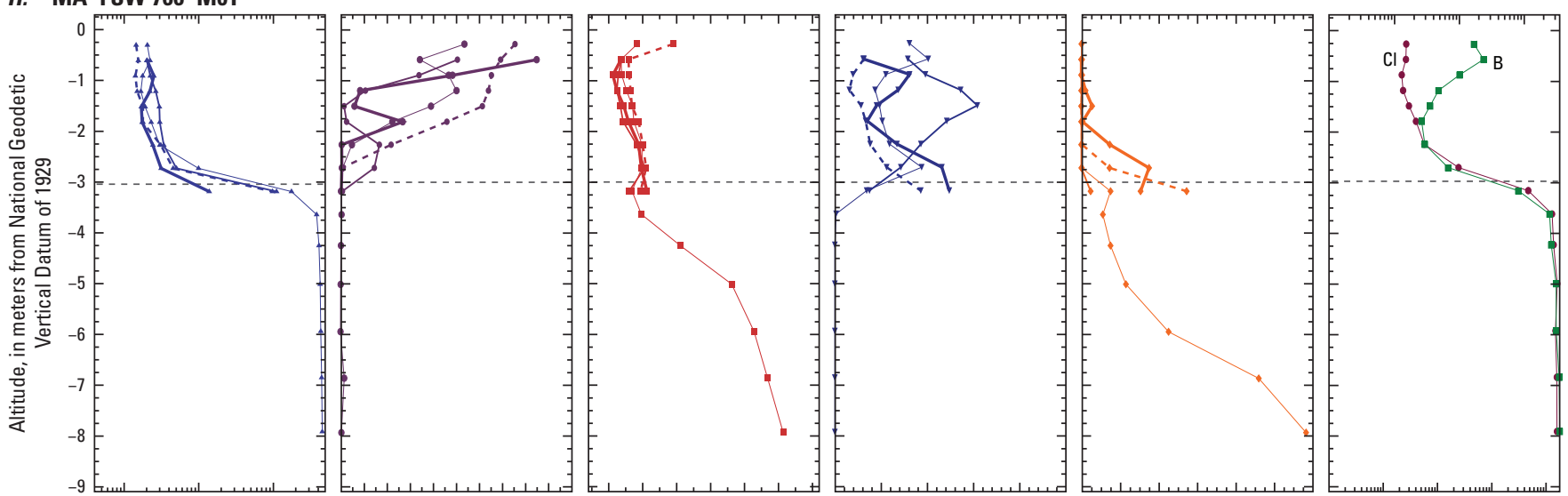

\section{MA-FSW 770-M01}
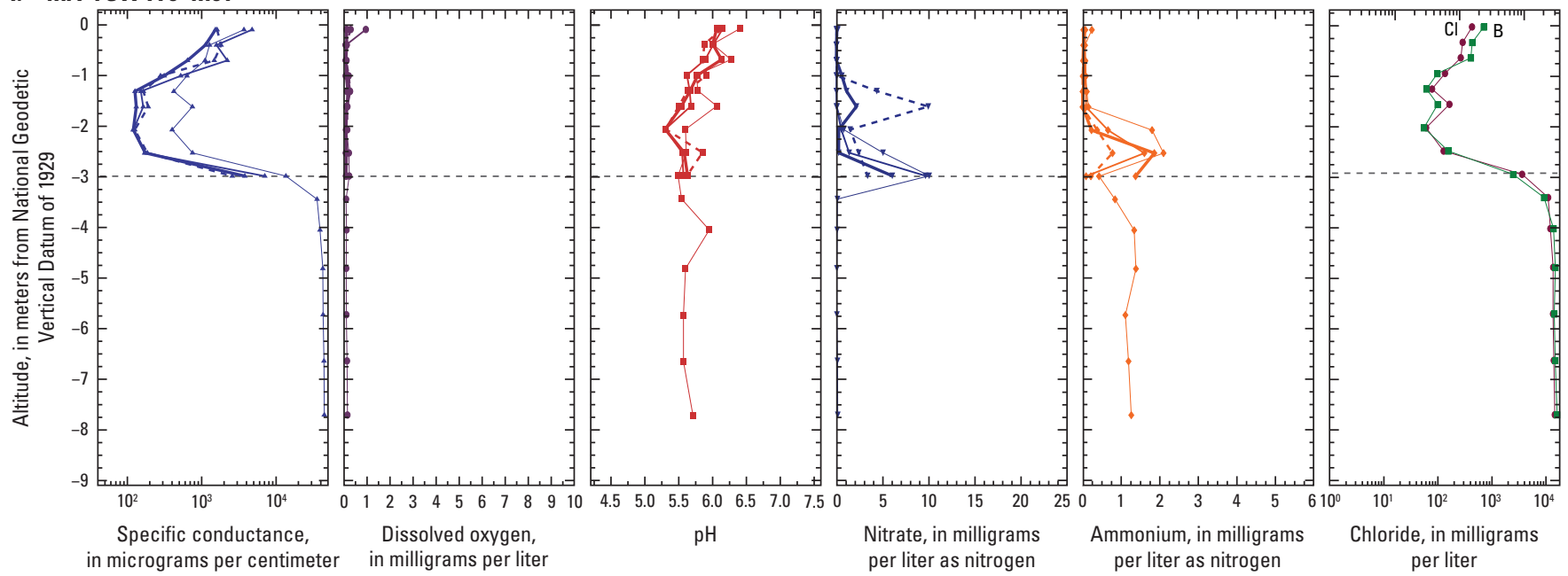

EXPLANATION

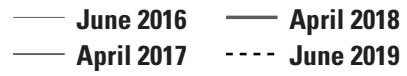

Estimated position of freshwater/saltwater boundary in June 2016-Measured as specific conductance greater than 3,000 micrograms per centimeter

Figure 1.1.-Continued 

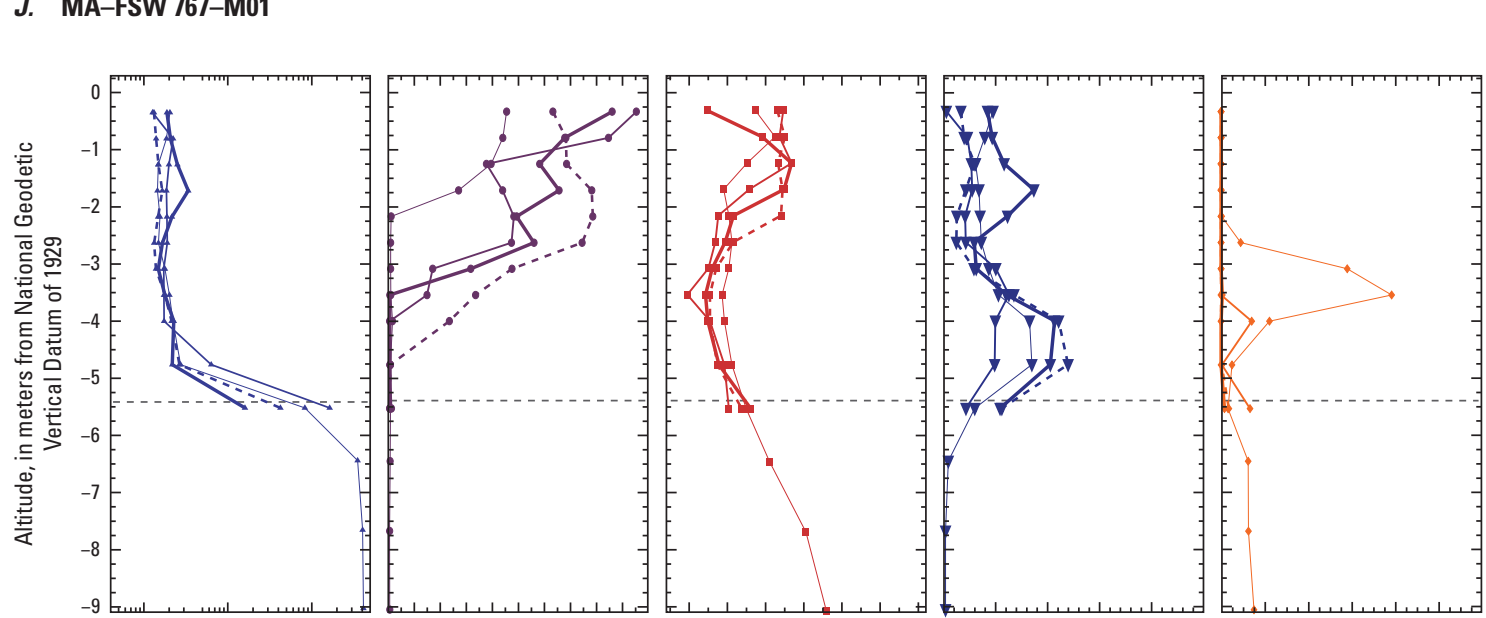

Boron, in micrograms per liter

\section{K. MA-FSW 768-M01}
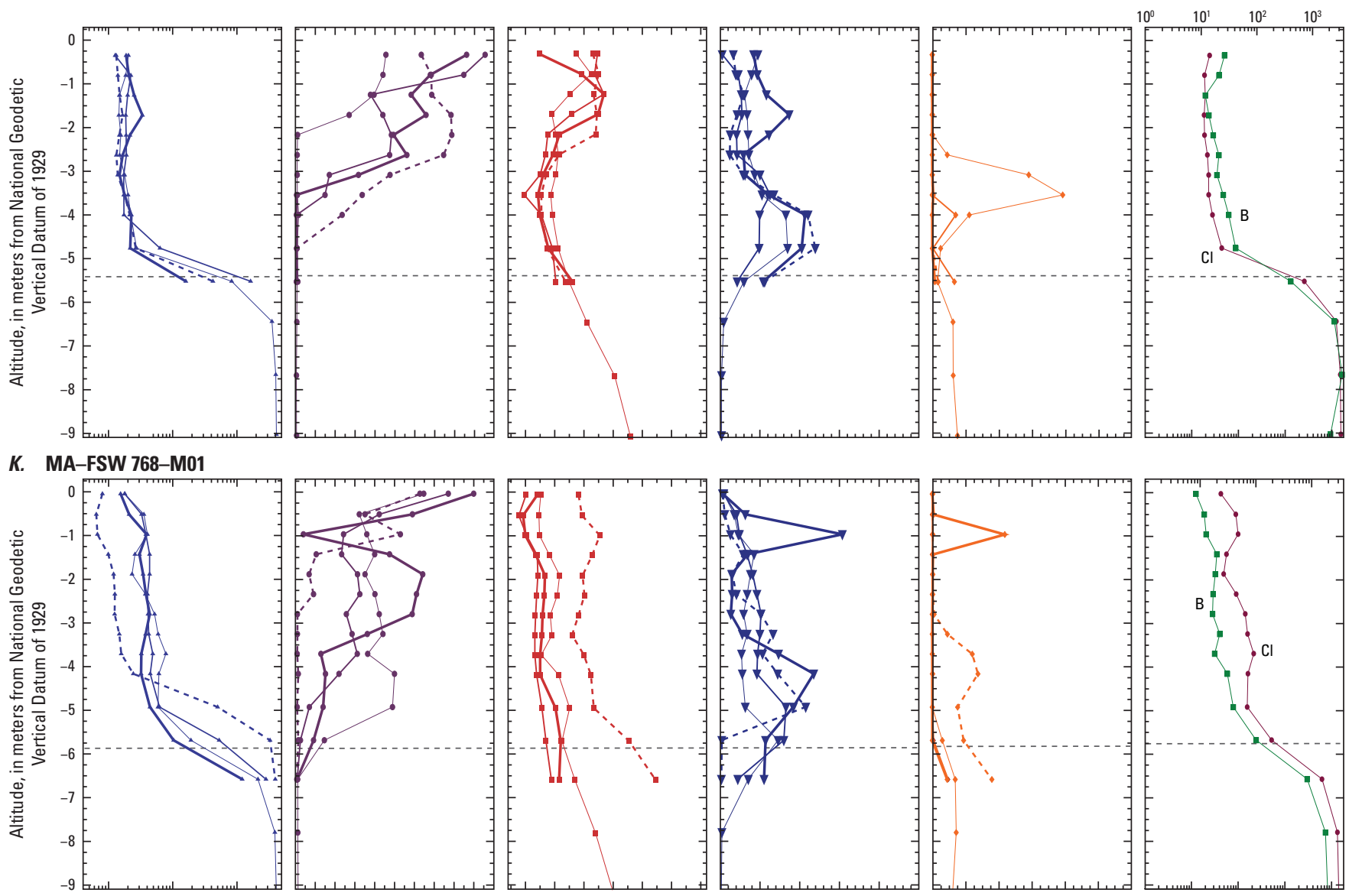

L. MA-FSW 769-M01
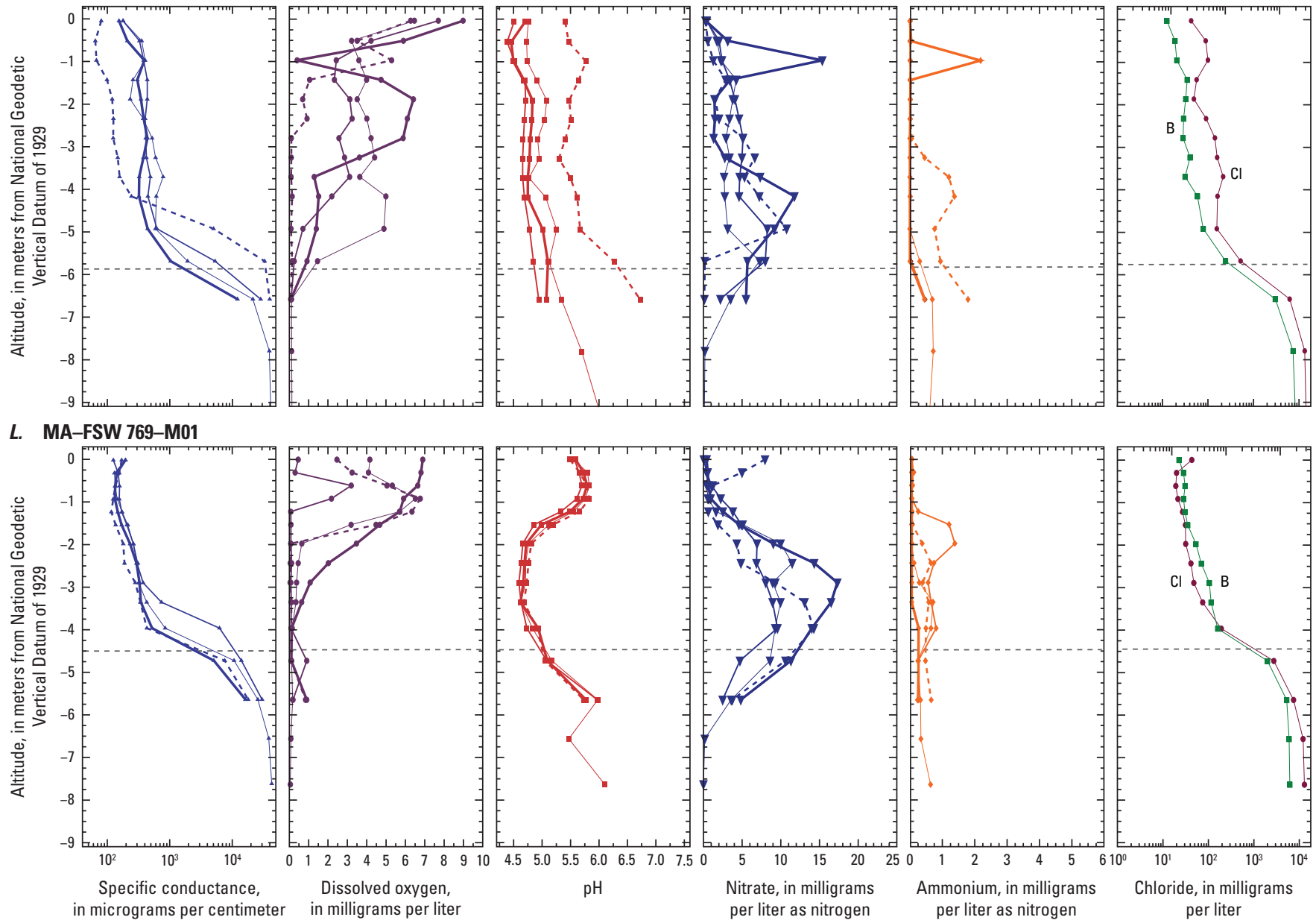

EXPLANATION

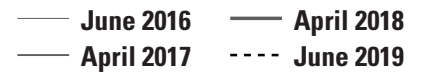

Estimated position of freshwater/saltwater boundary in June 2016-Measured as specific conductance greater than 3,000 micrograms per centimeter

Figure 1.1.-Continued 

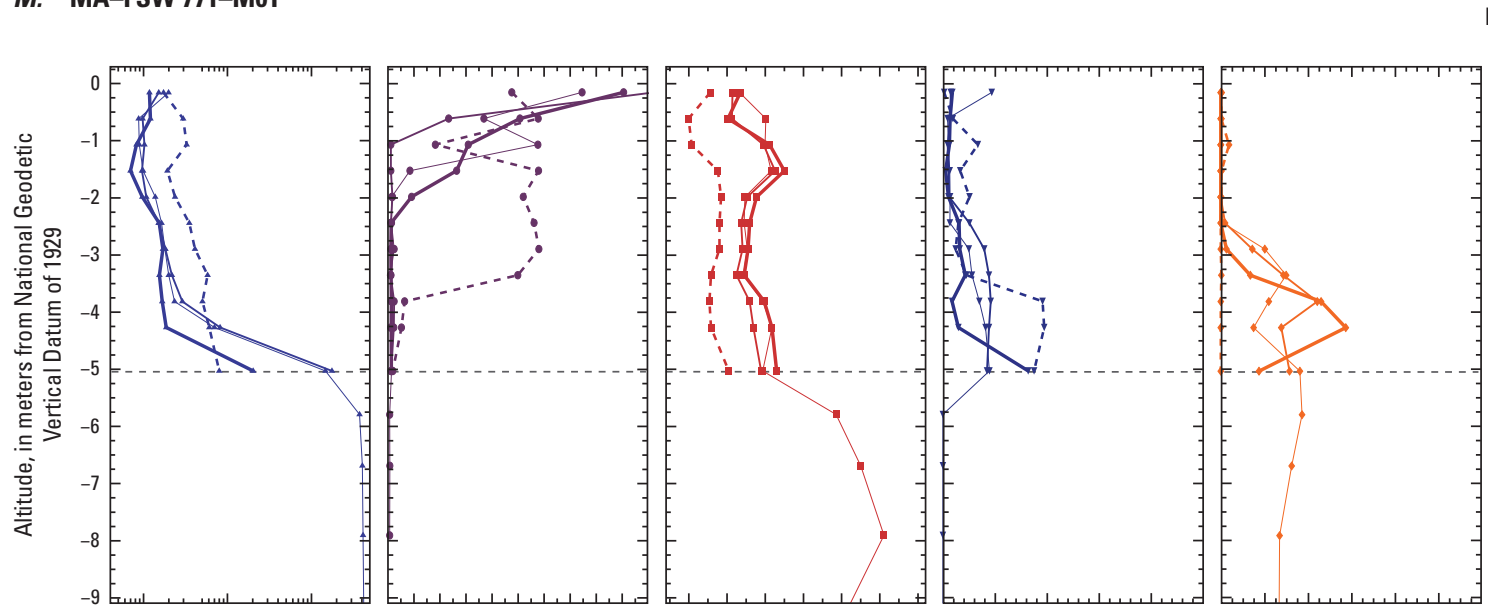

Boron, in micrograms per liter

\section{N. MA-FSW 772-M01}
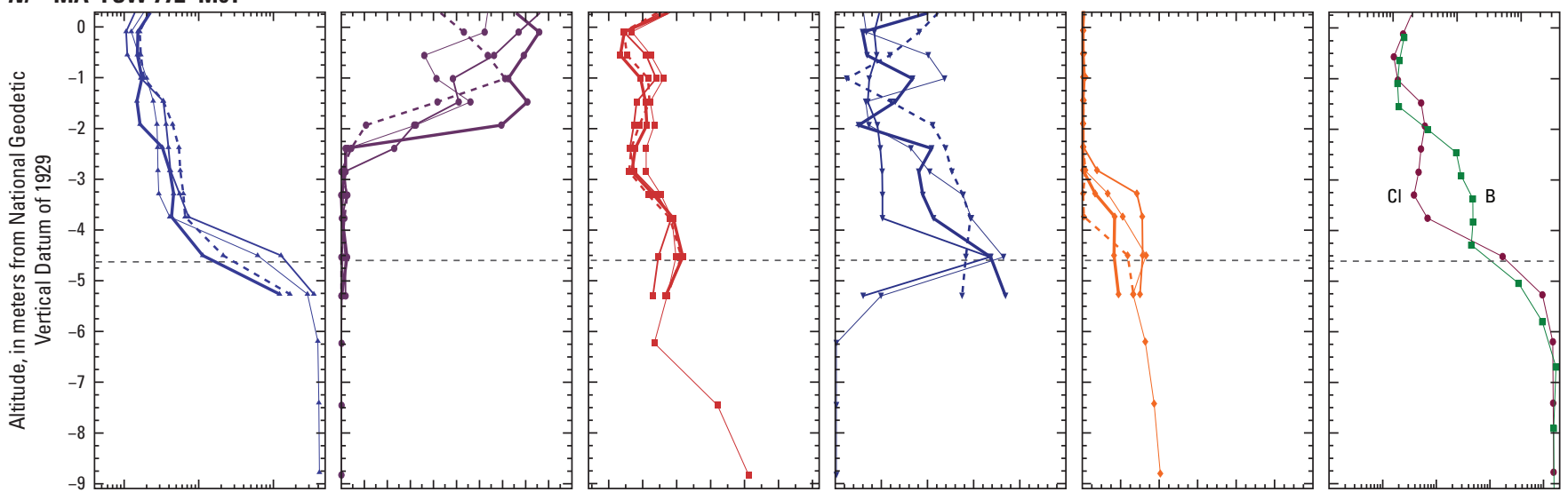

0. MA-FSW-724-M01 (location of this reference site is shown in figure 1)
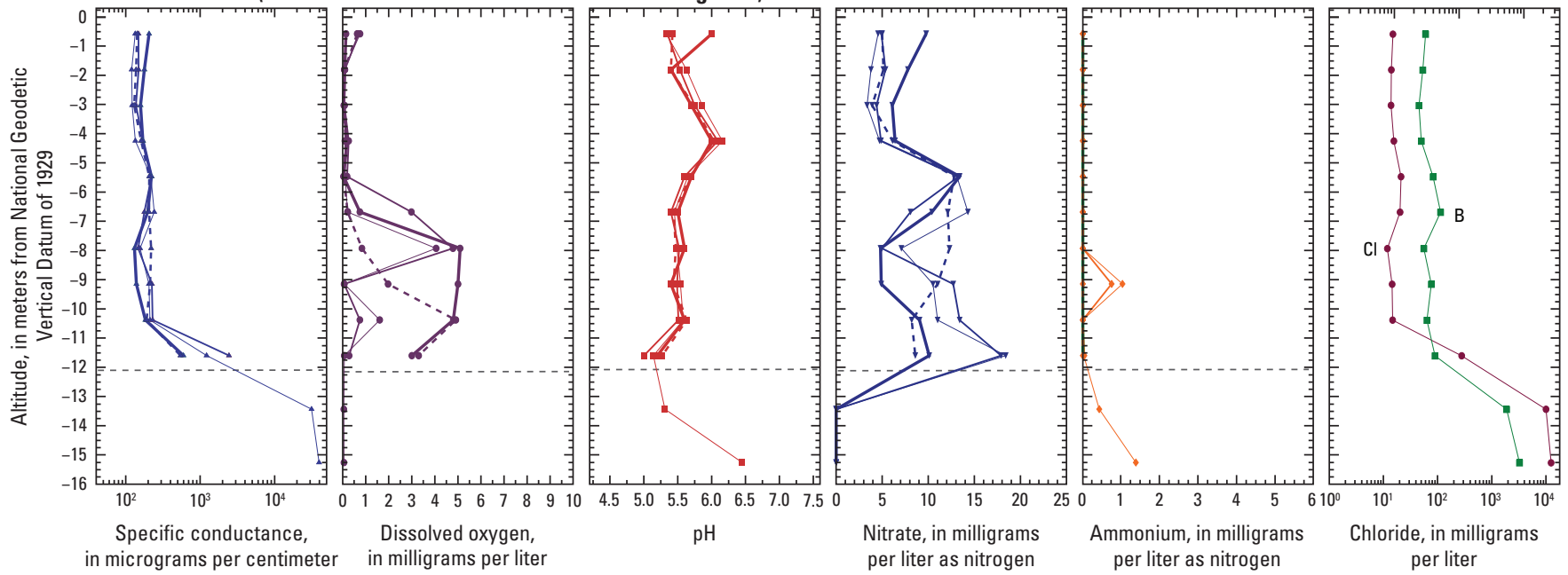

EXPLANATION

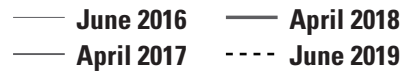

Estimated position of freshwater/saltwater boundary in June 2016-Measured as specific conductance greater than 3,000 micrograms per centimeter

Figure 1.1.-Continued 
A constant hydraulic conductivity value (79 meters per day) was applied to the entire section for the calculation of flow by using Darcy's Law. This value is the arithmetic mean of hydraulic conductivities of sediment collected at site F764 as determined from 13 applicable equations based on grainsize analysis, as described in the "Monitoring Network Design and Installation" section.

Discrete manual measurements of groundwater levels made during sampling rounds exhibited significant changes at the hour scale owing to tidal effects. For this reason, snapshots from the continuous water-level records collected between June 27 and August 2, 2016, were used for the mass-flux calculations. For each of the three water-table configurations presented in figure 6 in the main report and described in the "Groundwater Levels" section in this appendix, a constant hydraulic gradient was applied to each grid column. Gradients were determined graphically from water-table contours produced from the continuous water-level records.

The concentration field was developed by contouring lines of equal nitrate concentration through the section (fig. $12 A$ in the main report). This approach assumes there are continuous zones of elevated nitrate concentration that are connected laterally between the widely spaced sites (108-165 m). The water-table position was assigned a concentration of 0.1 milligram per liter as nitrogen. Contours were extrapolated to the bottom of the section near the freshwater/ saltwater boundary. The concentration contours were then interpolated spatially onto a finely spaced grid by using a built-in algorithm in ArcGIS (Esri, 2020) that uses a thin-plate spline interpolation technique (Topo-to-Raster). The interpolated raster was then merged with the grid along the section to obtain mean concentrations for each cell (fig. $12 \mathrm{~A}$ in the main report).

\section{References Cited}

Barbaro, J.R., Belaval, M., Truslow, D.B., LeBlanc, D.R., Cambareri, T.C., and Michaud, S.C., 2019, Hydrologic site assessment for passive treatment of groundwater nitrogen with permeable reactive barriers, Cape Cod, Massachusetts: U.S. Geological Survey Scientific Investigations Report 2019-5047, 39 p. [Also available at https://doi.org/10.3133/ sir20195047.]

CHEMetrics, 2018, Water analysis kits: CHEMetrics web page, accessed October 24, 2018, at https:/www.cheme trics.com/.

Devlin, J.F., 2015, HydrogeoSieveXL-An Excel-based tool to estimate hydraulic conductivity from grain-size analysis: Hydrogeology Journal, v. 23, no. 4, p. 837-844. [Also available at https://doi.org/10.1007/s10040-015-1255-0.]
Esri, 2020, Topo to raster (3D analyst): Esri ArcGIS Pro tool reference, accessed May 1, 2020, at https://pro.arcgis.com/ en/pro-app/latest/tool-reference/3d-analyst/topo-toraster.htm.

Fishman, M.J., ed., 1993, Methods of analysis by the U.S. Geological Survey National Water Quality LaboratoryDetermination of inorganic and organic constituents in water and fluvial sediments: U.S. Geological Survey OpenFile Report 93-125, 217 p. [Also available at https://doi.org/ 10.3133/ofr93125.]

Fishman, M.J., and Friedman, L.C., 1989, Methods for determination of inorganic substances in water and fluvial sediments: U.S. Geological Survey Techniques of WaterResources Investigations, book 5, chap. A1, 545 p. [Also available at https://doi.org/10.3133/twri05a1.]

Garabedian, S.P., LeBlanc, D.R., Gelhar, L.W., and Celia, M.A., 1991, Large-scale natural gradient tracer test in sand and gravel, Cape Cod, Massachusetts-2. Analysis of spatial moments for a nonreactive tracer: Water Resources Research, v. 27, no. 5, p. 911-924. [Also available at https://doi.org/10.1029/91WR00242.]

Kenney, T.A., 2010, Levels at gaging stations: U.S. Geological Survey Techniques and Methods, book 3, chap. A19, 60 p. [Also available at https://doi.org/10.3133/ tm3a19.]

McCobb, T.D., LeBlanc, D.R., Walter, D.A., Hess, K.M., Kent, D.B., and Smith, R.L., 2003, Phosphorus in a ground-water contaminant plume discharging to Ashumet Pond, Cape Cod, Massachusetts, 1999: U.S. Geological Survey Water-Resources Investigations Report 02-4306, 70 p. [Also available at https://doi.org/10.3133/ wri024306.]

McCobb, T.D., LeBlanc, D.R., Barbaro, J.R., and Belaval, M., 2019, Baseline groundwater-quality data from a densely developed coastal neighborhood, Falmouth, Massachusetts (2016-2020) (ver. 3.0, April 2021): U.S. Geological Survey data release, accessed December 2021 at https://doi.org/ 10.5066/P9GEMMN6.

Patton, C.J., and Kryskalla, J.R., 2003, Methods of analysis by the U.S. Geological Survey National Water Quality Laboratory-Evaluation of alkaline persulfate digestion as an alternative to Kjeldahl digestion for determination of total and dissolved nitrogen and phosphorus in water: U.S. Geological Survey Water-Resources Investigations Report 03-4174, 33 p. [Also available at https://doi.org/10.3133/ wri034174.]

Patton, C.J., and Kryskalla, J.R., 2011, Colorimetric determination of nitrate plus nitrite in water by enzymatic reduction, automated discrete analyzer methods: U.S. Geological Survey Techniques and Methods, book 5, chap. B8, 34 p. [Also available at https://doi.org/10.3133/tm5b8.] 
Repert, D.A., Barber, L.B., Hess, K.B., Keefe, S.H., Kent, D.B., LeBlanc, D.R., and Smith, R.L., 2006, Long-term natural attenuation of carbon and nitrogen within a groundwater plume after removal of the treated wastewater source: Environmental Science \& Technology, v. 40, no. 4, p. 1154-1162. [Also available at https://doi.org/10.1021/ es051442j.]

Rounds, S.A., Wilde, F.D., and Ritz, G.F., 2013, Dissolved oxygen (ver. 3.0): U.S. Geological Survey Techniques of Water Resources Investigations, book 9, chap. A6, sec. 6.2, accessed March 2020 at https://water.usgs.gov/owq/ FieldManual/Chapter6/6.2_v3.0.pdf.

Rydlund, P.H., Jr., and Densmore, B.K., 2012, Methods of practice and guidelines for using survey-grade global navigation satellite systems (GNSS) to establish vertical datum in the United States Geological Survey: U.S. Geological Survey Techniques and Methods, book 11, chap. D1, 102 p. with appendixes [Also available at https://doi.org/10.3133/ tm11d1.]

Savoie, J.G., LeBlanc, D.R., Fairchild, G.M., Smith, R.L., Kent, D.B., Barber, L.B., Repert, D.A., Hart, C.P., Keefe, S.H., and Parsons, L.A., 2012, Groundwater-quality data for a treated-wastewater plume near the Massachusetts Military Reservation, Ashumet Valley, Cape Cod, Massachusetts, 2006-08: U.S. Geological Survey Data Series 648, 11 p., 1 CD-ROM [Also available at https://doi.org/10.3133/ds648.]

Struzeski, T.M., DeGiacomo, W.J., and Zayhowski, E.J., 1996, Methods of analysis by the U.S. Geological Survey National Water Quality Laboratory-Determination of dissolved aluminum and boron in water by inductively coupled plasma-atomic emission spectrometry: U.S. Geological Survey Open-File Report 96-149, 17 p. [Also available at https://doi.org/10.3133/ofr96149.]
U.S. Geological Survey, 2018, General introduction for the "National Field Manual for the Collection of Water-Quality Data" (ver. 1.1, June 2018): U.S. Geological Survey Techniques and Methods, book 9, chap. A0, 4 p. [Also available at https://doi.org/10.3133/tm9A0.]

U.S. Geological Survey, 2019, Specific conductance: U.S. Geological Survey Techniques and Methods, book 9, chap. A6.3, 15 p. [Also available at https://doi.org/10.3133/ tm9A6.3.] [Supersedes USGS Techniques of WaterResources Investigations, book 9, chap. A6.3, version 1.2.]

U.S. Geological Survey, 2020a, USGS water data for the Nation: U.S. Geological Survey National Water Information System database, accessed March 10, 2020, at https://doi.org/10.5066/F7P55KJN.

U.S. Geological Survey, 2020b, Policy for procedure and publishing discrete groundwater-level records: U.S. Geological Survey Office of Groundwater Technical Memorandum 2017.04, accessed March 10, 2020, at https://water .usgs.gov/ogw/policy/discrete-data-guidance/.

U.S. Geological Survey, 2021, Measurement of pH: U.S. Geological Survey Techniques and Methods, book 9, chap. A6.4, 21 p. [Also available at https://doi.org/10.3133/ tm9A6.4.] [Supersedes USGS Techniques of WaterResources Investigations, book 9, chap. A6.4, version 2.0.]

Wilde, F.D., 2006, Temperature: U.S. Geological Survey Techniques of Water-Resources Investigations, book 9, chap. 6.1 [Also available at https://doi.org/10.3133/ twri09A6.1.]

Weiskel, P.K., and Howes, B.L., 1991, Quantifying dissolved nitrogen flux through a coastal watershed: Water Resources Research, v. 27, no. 11, p. 2929-2939. [Also available at https://doi.org/10.1029/91WR01910.] 

For more information about this report, contact: Director, New England Water Science Center U.S. Geological Survey 10 Bearfoot Road Northborough, MA 01532 dc_nweng@usgs.gov or visit our website at https://www.usgs.gov/centers/new-englandwater

Publishing support provided by the Pembroke and Rolla Publishing Service Centers 


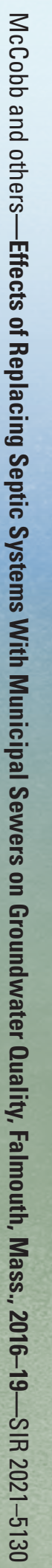

